UNIVERSIDADE DE SÃO PAULO

FACULDADE DE FILOSOFIA, LETRAS E CIÊNCIAS HUMANAS

PROGRAMA DE PÓS-GRADUAÇÃO EM CIÊNCIA POLÍTICA

AMANDA MARIACAMPANINI PEREIRA

A lógica da aÇão na Reforma do Código Florestal

SÃo PAULO

2013 
UNIVERSIDADE DE SÃO PAULO

FACULDADE DE FILOSOFIA, LETRAS E CIÊNCIAS HUMANAS

PROGRAMA DE PÓS-GRADUAÇÃO EM CIÊNCIA POLÍTICA

\section{A lógiCa da AÇão na ReForma do Código Florestal}

AMANDA MARIA CAMPANINI PEREIRA

Dissertação apresentada à Faculdade de Filosofia, Letras e Ciências Humanas da Universidade de São Paulo para obtenção do título de Mestre em Ciência Política.

Orientador: Prof. Dr. Fernando de Magalhães Papaterra Limongi 
Nome: PEREIRA, Amanda Maria Campanini

Título: A lógica da ação na reforma do Código Florestal

Dissertação apresentada à Faculdade de Filosofia, Letras e Ciências Humanas da Universidade de São Paulo para obtenção do título de Mestre em Ciência Política.

Aprovado em:

Banca Examinadora

Prof. Dr.

Instituição:

Julgamento:

Assinatura:

Prof. Dr.

Instituição:

Julgamento:

Assinatura:

Prof. Dr.

Instituição:

Julgamento:

Assinatura: 


\section{Agradecimentos}

Peço licença para desconsiderar regras sintáticas, pois neste momento tento compreender a grandiosidade necessária dos agradecimentos. Acredito que essa intenção não será totalmente cumprida, mas espero que todos que participaram desta jornada sintam-se representados.

Em primeiro lugar, agradeço ao meu orientador, professor Fernando Limongi, pelo interesse e dedicação que me foram dados. Sua aptidão em receber minhas ideias ainda sem muita lógica e, então, construir questões racionais e pertinentes, foi fundamental para o desenvolvimento deste trabalho. Sou honrada por ter sido introduzida no campo de estudos legislativos por uma das maiores referências da área.

Aos professores Eduardo Marques e Wagner Mancuso, que participaram da minha banca de qualificação e ofereceram contribuições substanciais para o aprimoramento deste estudo.

Ao DCP/USP, em especial, Rai e Vasne, pelo fornecimento de condições exemplares para nosso desenvolvimento acadêmico.

À Cynthia Cury, por tudo. Não poderia contar com melhor pessoa para aprender sobre relacionamento institucional, ética e responsabilidade. Nossa parceria simboliza um marco em minha trajetória.

À Suely de Araújo, pela prontidão em auxiliar-me nessa temática que tanto domina. E aos demais entrevistados, pela disponibilidade em compartilhar suas vivências.

À Patri, na pessoa de Michel Neil, tanto pelas oportunidades que me foram dadas quanto pelo apoio e incentivo que recebi no início desta etapa.

Aos colegas e amigos Bruno Boti, Danilo Buscatto, Fabrício Vasselai, Helena Martins, Jaqueline Zulini e Thiago Nascimento, por me receberem e me "co-orientarem" tão bem nesse período em São Paulo. À Ellen, Luiza e Mariana, hora longe, hora perto, por sempre estarem presentes.

A minha família, em especial, meus pais e avós, cujos exemplos de vida formaram meus valores e ideais. Nada disso seria possível sem o amparo e carinho que recebi.

Ao Victor, por todas nossas vitórias e pelo amor que lógica alguma é capaz de 
descrever.

Por fim, agradeço ao Conselho Nacional de Desenvolvimento Científico e Tecnológico $(\mathrm{CNPq})$, pela concessão da bolsa de mestrado e pelo apoio financeiro para a realização desta pesquisa. 


\section{RESUMO}

PEREIRA, A. M. C. (2013). A Lógica da Ação na Reforma do Código Florestal. Dissertação de Mestrado. Faculdade de Filosofia, Letras e Ciências Humanas, Universidade de São Paulo, São Paulo.

O novo Código Florestal (Lei 12.651 de 2012) tramitou por quase 13 anos no Congresso Nacional e obteve grande repercussão social. A maior parte do processo foi caracterizada como vitória da bancada ruralista e derrota governamental, em um momento no qual o Executivo possuía maioria legislativa. Entretanto, o conflito não se deu com a variável oposição e governo, mas entre coalizões rurais e ambientais. Este trabalho busca apontar quais recursos utilizados pelas coalizões foram determinantes no resultado da política. Para isso foi analisada a fase inicial da tramitação da matéria na Câmara dos Deputados, ou seja, o período desde a instalação da comissão especial até a aprovação no Plenário da Casa. As audiências públicas e o parecer da comissão revelaram quais são os interesses em jogo e como eles se organizaram para o conflito. A literatura norte-americana sobre formação de agenda e comportamento legislativo subsidiou a compreensão da atuação das lideranças - entendidas como os parlamentares que coordenaram os trabalhos das coalizões. Após apontar os principais recursos utilizados por elas, demonstra-se o quanto algumas estratégias foram determinantes no resultado da política. Constatou-se que a definição de uma proposta politicamente viável pelos representantes da agricultura foi determinante na capacidade de construção e mobilização dessa coalizão. Além disso, considerando que o processo decisório também se tornou objeto de conflito, os procedimentos de discussão e votação da matéria foram escolhidos pelas lideranças não apenas para defender a proposta, mas também para facilitar a obtenção de recompensa eleitoral.

Palavras-chave: Coalizões. Código Florestal. Comportamento Legislativo. Formação de Agenda. Representação de Interesses. 


\begin{abstract}
PEREIRA, A. M. C. (2013). The Logic of Forest Code Reform Action. Dissertação de Mestrado. Faculdade de Filosofia, Letras e Ciências Humanas, Universidade de São Paulo, São Paulo.

The new Forest Code took almost 13 years in National Congress and had considerable social impact. Most of the process was characterized as a rural victory and governmental defeat, at a time when the Executive held legislative majority. However, the conflict could not be explained by the variable opposition and government, but by rural and environmental coalitions. This work seeks to appoint what coalition resources were determinant in the policy outcome. The first phase of the legislative process in the House of Representatives were analyzed - from the installation of the special committee until the approval on the House floor. The hearings and the committee report described the interests involved and how they organized themselves. The American literature about agenda setting and legislative behavior supported the evaluation about leader's action - understood as legislators who coordinated the coalition's work. After pointing out the key resources used by them, it is shown how some strategies were decisive in the outcome of the policy. It was found that the definition of a politically viable proposal by representatives of agriculture activities was crucial to the capacity of building this coalition. Moreover, considering that the decision-making process also became object of dispute, the procedures for discussion and vote were chosen by the leadership not only to defend the proposal, but also to facilitate the achievement of electoral recompense.
\end{abstract}

Keywords: Agenda Setting. Coalition. Forest Code. Legislative Behavior. Representation of Interests. 


\section{LiSTA DE GRÁFICOS}

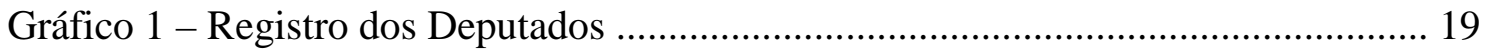

Gráfico 2 - Mapa Regional dos Ruralistas .................................................................. 27

Gráfico 3 - Distribuição Partidária dos Ruralistas na Câmara dos Deputados

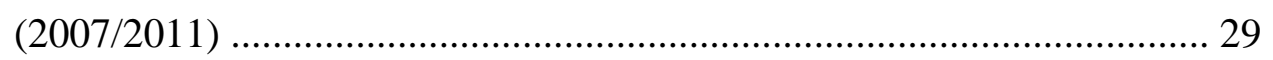

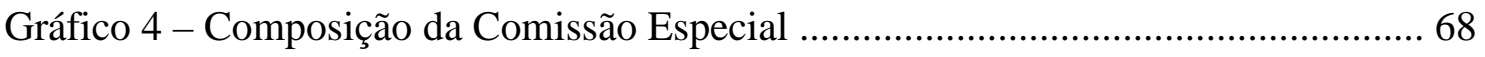

Gráfico 5 - Representação Partidária na Comissão .......................................................... 69

Gráfico 6 - Convidados Solicitados nos Requerimentos de Audiências Públicas 74

Gráfico 7 - Participações nas Audiências ...................................................................... 76

Gráfico 8 - Doações estimadas aos membros da Comissão ........................................ 85

\section{LISTA DE QUADROS}

Quadro 1 - Cronologia de tramitação do PL 1.876/99 e eventos relacionados 46

\section{LISTA DE TABELAS}

Tabela 1 - Áreas Legalmente Disponíveis para a Atividade Agrícola ......................... 48

Tabela 2 - Cobertura original e área desmatada de cada bioma em 2002 .................... 50

Tabela 3 - Votação do Texto-Base no Plenário da Câmara ............................................ 80

Tabela 4 - Votação da Emenda Ruralista ...................................................................... 81 


\section{LISTA DE ABREVIATURAS E SIGLAS}

ABAG Associação Brasileira do Agronegócio

ABIPT Associação Brasileira das Instituições de Pesquisa Tecnológica

ANC Assembleia Nacional Constituinte

APP Área de Preservação Permanente

CAPADR Comissão de Agricultura, Pecuária, Abastecimento e Desenvolvimento Rural

CCJ Comissão de Constituição, Justiça e Cidadania

CCT Comissão de Ciência, Tecnologia, Inovação, Comunicação e Informática

CMADS Comissão de Meio Ambiente e Desenvolvimento Sustentável

CNA Confederação Nacional da Agricultura e Pecuária

CNI Confederação Nacional da Indústria

$\mathrm{CNPq} \quad$ Conselho Nacional de Desenvolvimento Científico e Tecnológico

Conama Conselho Nacional do Meio Ambiente

CONTAG Confederação Nacional dos Trabalhadores na Agricultura

COP Conferência das Partes

CPMI Comissão Parlamentar Mista de Inquérito

CRA Comissão de Agricultura e Reforma Agrária

DCN Diário do Congresso Nacional

DEM Democratas

DIAP Departamento Intersindical de Assessoria Parlamentar

Embrapa Empresa Brasileira de Pesquisa Agropecuária

FBOMS Fórum Brasileiro de Organizações Não-Governamentais e Movimentos Sociais para o Meio Ambiente e o Desenvolvimento

FPA Frente Parlamentar da Agropecuária

FPAmb Frente Parlamentar Ambientalista

Frencoop Frente Parlamentar do Cooperativismo

Funatura Fundação Pró-Natureza

GTA Grupo de Trabalho Amazônico 
Ibama Instituto Brasileiro do Meio Ambiente e dos Recursos Naturais Renováveis

IBDF Instituto Brasileiro de Desenvolvimento Florestal

Imazon Instituto do Homem e Meio Ambiente da Amazônia

Incra Instituto Nacional de Colonização e Reforma Agrária

INESC Instituto de Estudos Sócioeconômicos

Inpa Instituto Nacional de Pesquisas da Amazônia

Inpe Instituto Nacional de Pesquisas Espaciais

Ipam Instituto de Pesquisa Ambiental da Amazônia

ISA Instituto Socioambiental

MAPA Ministério da Agricultura, Pecuária e Abastecimento

MMA Ministério do Meio Ambiente

MP Medida Provisória

MST Movimento dos Trabalhadores Rurais Sem Terra

OCB Organização das Cooperativas do Brasil

PCdoB Partido Comunista do Brasil

PDS Partido Democrático Social

PDT Partido Democrático Trabalhista

PEC Proposta de Emenda à Constituição

PFL Partido da Frente Liberal

PL Projeto de Lei

PLV Projeto de Lei de Conversão

PMDB Partido do Movimento Democrático Brasileiro

PSB Partido Socialista Brasileiro

PSDB Partido da Social Democracia Brasileira

PSOL Partido Socialismo e Liberdade

PT Partido dos Trabalhadores

PTB Partido Trabalhista Brasileiro

PV Partido Verde

Rede Pró-UCs Rede Pró-Unidades de Conservação da Natureza

RICD Regimento Interno da Câmara dos Deputados 
STF

Supremo Tribunal Federal

TSE

Tribunal Superior Eleitoral

UDR

União Democrática Ruralista

UNICA

União da Indústria da Cana-de-açúcar 


\section{A LÓGICA DA AÇÃO NA REFORMA DO CÓDIGO FLORESTAL}

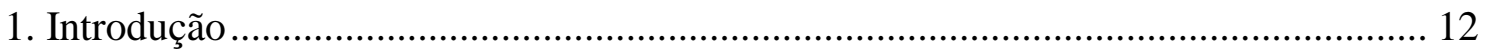

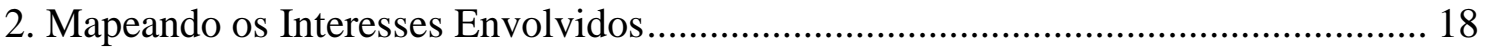

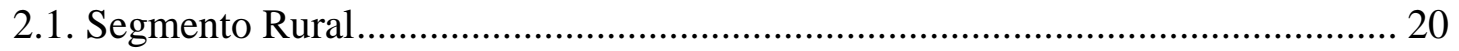

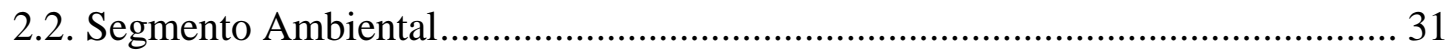

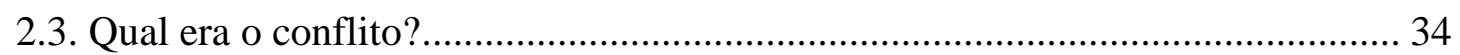

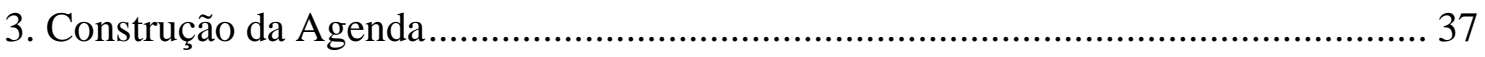

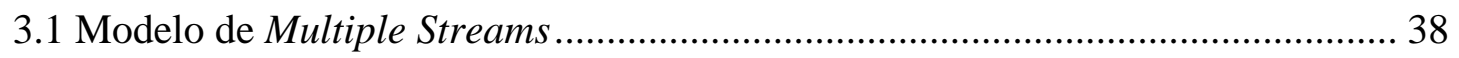

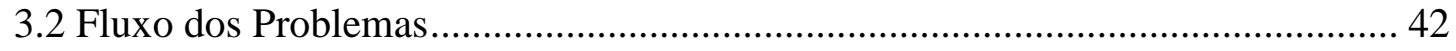

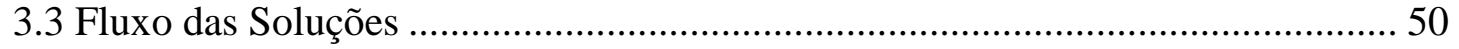

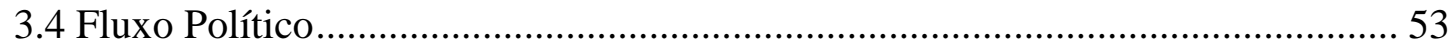

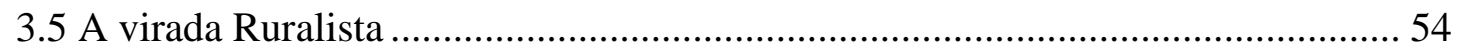

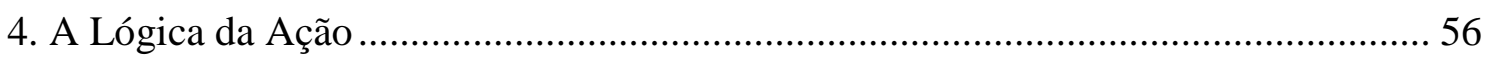

4.1. Natureza da política e percepção dos cidadãos …………................................... 58

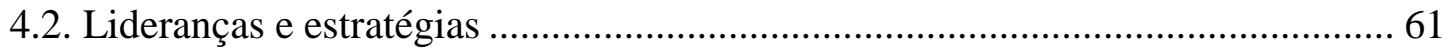

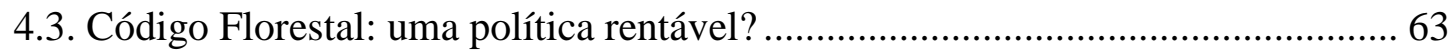

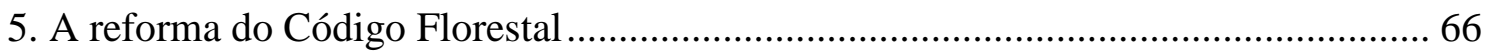

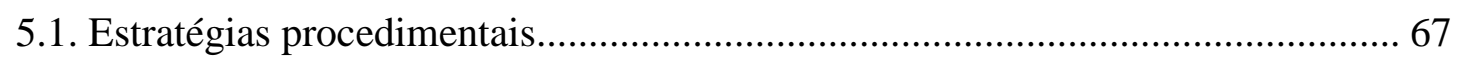

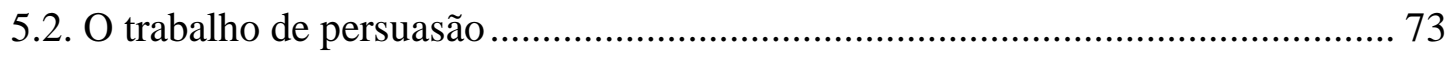

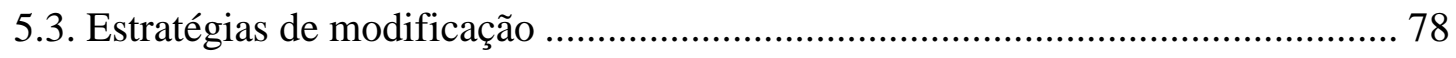

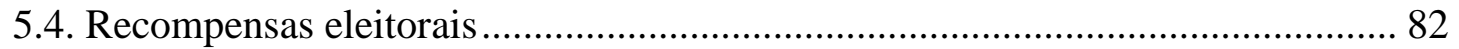

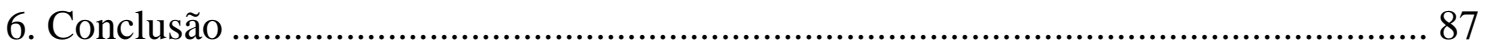

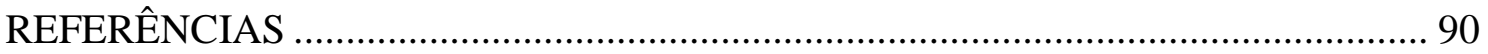

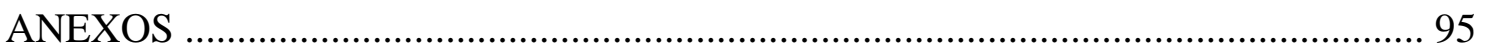




\section{Introdução}

O processo de reforma do Código Florestal foi caracterizado por alguns como um dos maiores debates desde a Assembleia Constituinte. A matéria mobilizou intensamente os setores público e privado. Além disso, há relatos que afirmam ter sido esta a questão que mais ocupou a Presidência da República no mandato de Dilma Rousseff. Repleta de pontos polêmicos que envolvem conflitos entre preservação ambiental e produção rural, a reforma foi discutida no Congresso Nacional por mais de uma década. O resultado das mudanças foi considerado por muitos como uma vitória dos representantes rurais.

A Lei Florestal estabelece normas sobre a proteção da vegetação, áreas de preservação permanente, de reserva legal e exploração florestal. De forma genérica, dispõe sobre as condições e quantidades de terras destinadas à preservação ambiental, o que interfere em como e quanto os proprietários rurais deverão se adaptar para estarem na legalidade. Em outras palavras, qual parcela da propriedade deverá ser ambientalmente recuperada e preservada? Ou melhor, qual o tamanho da perda da produção e, fora isso, do desembolso necessário para recuperar a vegetação? Assim, as normas envolvem diretamente os interesses ambientais e rurais, com custos concretos para o segundo segmento. O conflito se agrava na medida em que a atividade agrária foi predominante na trajetória histórica do país. E, por outro lado, esse mesmo país é detentor da maior biodiversidade do planeta.

A reforma em discussão teve seu início formal na Câmara dos Deputados com um projeto de lei de 1999. Mas o debate sobre alguns dos pontos mais importantes da matéria ocorria desde 1995, quando o desmatamento na Amazônia chegou ao pico de quase 30 mil km² no ano. Em 1998 foi sancionada a Lei de Crimes Ambientais, de autoria do Poder Executivo. Em 2001, através de uma medida provisória, a área destinada à reserva legal na Amazônia aumentou de 50 para 80\%. Contudo, mesmo com esses avanços na legislação, outro pico de desmatamento ocorreu em 2004, fazendo com que novas medidas fossem tomadas. Foram editadas a Lei de Gestão das Florestas Públicas, a Lei da Mata Atlântica e a regulamentação das infrações e sanções administrativas ao meio ambiente. Enquanto isso, a tramitação do projeto de reforma no Código Florestal de 1999 encontrava-se vagarosa nas comissões permanentes. 
Apenas em 2009, dez anos depois do primeiro projeto, a reforma florestal ganhou forças. Encabeçada pelo deputado Valdir Colatto (PMDB/PR) e 46 coautores, foi apresentada outra proposta de mudança - que foi apensada ao projeto de 1999. Entretanto, por seu mérito abranger a competência de oito comissões permanentes, foi criada uma Comissão Especial destinada à análise da matéria, o que era regimentalmente previsto. Após dez meses de trabalhos, a Comissão propôs mudanças na legislação definidas no parecer de Aldo Rebelo (PCdoB/SP). O parecer, significativamente, foi dedicado aos agricultores brasileiros. Em face à tradicional associação de agricultura com latifúndio e retrocesso, Rebelo foi no mínimo corajoso ao fazer essa dedicatória. A distinção que o deputado tentara fazer, entre agricultores e donos de propriedade agrícolas, entre trabalhadores e pequenos proprietários rurais, de um lado, e ruralistas ou grandes proprietários de terra de outro, não foi bem recebida ou entendida.

Sem o intuito de examinar o mérito do conflito, este estudo se motivou pelas excepcionalidades da tramitação legislativa da reforma. De forma desviante das principais proposições ambientais, o Legislativo não foi pautado por projeto do Executivo. A expressiva aprovação do texto-base da reforma no Plenário da Câmara colocou governo e oposição do mesmo lado. A alta disciplina partidária nessa votação se revelou na maioria dos partidos, com exceção do PT, que se dividiu em 45 favoráveis e 35 contrários, mesmo com a indicação favorável da liderança ${ }^{1}$. Destoando de sua trajetória histórica de disciplina nas votações, a divisão do partido simboliza a falta de consenso sobre a matéria não apenas entre os parlamentares, mas também dentro do governo. O conflito não se deu com a dimensão governo e oposição, mas defensores ou opositores da proposta rural. Conforme discurso de Aldo Rebelo durante a votação mencionada:

\footnotetext{
"Não é uma matéria de interesse de governo ou de oposição, não é uma matéria de interesse partidário, porque defensores da agricultura e do meio ambiente que têm posições opostas existem em todos os partidos, quase sem exceção. Isso mostra que não há corte ideológico partidário institucional de governo e de oposição nessa matéria." (REBELO, 2011, p. 8)
}

\footnotetext{
${ }^{1}$ Inicialmente, é válido explicar que ocorreram duas votações no Plenário da Câmara: (1) a do texto-base, referente ao substitutivo oferecido pelo Aldo Rebelo e posteriormente negociado com o governo; e, (2) a da emenda 164, oferecida pela bancada ruralista abrangendo pontos mais conflituosos da matéria.
} 
O processo legislativo em análise foi condicionado, portanto, pela atuação das coalizões dos interesses envolvidos. Quais recursos estavam disponíveis para elas e quais estratégias foram determinantes no resultado da política? A primeira hipótese é a de que a definição da natureza da política e a apropriação dos recursos institucionais determinaram algumas vitórias da coalizão ruralista. Definir a natureza da política implica torná-la viável ou não eleitoralmente, dispersando ou concentrando custos e benefícios. Após criar uma proposta viável, caberá à coalizão definir os procedimentos mais apropriados para garantir sua defesa e, na medida do possível, aumentar seu apoio mobilizando e negociando com outros setores.

Nesse sentido, a organização do processo decisório também se torna objeto de conflito entre as coalizões. A visibilidade do processo pode ser desejada ou não pelos defensores e opositores da proposta. Votações nominais, votações em separado, audiências públicas e delegação de questões são alguns exemplos de procedimentos que podem ser desejados ou não para facilitar a percepção do vínculo da política com a atuação do parlamentar. A quem cabe definir o processo? Segundo a teoria de Douglas Arnold (1990), as coalizões são formadas por líderes e pelo restante dos legisladores. Compete aos primeiros as escolhas sobre a proposta e os procedimentos a serem priorizados, e, aos segundos, referendar ou não essas escolhas. Para que ambos os atores decidam, conforme Arnold, são necessários cálculos sobre posições e efeitos, capazes de estimar as probabilidades de recompensas eleitorais, considerando ser a sobrevivência política a principal meta de um legislador. Quanto mais se entende o impacto das políticas nas preferências dos cidadãos, mais se aprende como os líderes elaboram suas estratégias e porque o Congresso delibera as propostas na forma como faz (ARNOLD, 1990, p. 14).

A teoria de Arnold dialoga de forma substancial com as percepções de John Kingdon (2011 [1984]), as quais demonstram como outros elementos afetam as decisões dos legisladores. Enquanto Arnold foca os efeitos do processo decisório e os atributos da política, Kingdon focaliza os estágios pré-decisórios, o que torna as duas obras complementares, e não excludentes (ARNOLD, 1990, p. 60, nota 1). Kingdon buscou responder por que alguns problemas, em um cenário competitivo, tornam-se importantes na agenda governamental. Sua hipótese é que a mudança na agenda é o 
resultado da convergência entre os fluxos dos problemas, das soluções e da própria política, em momentos nos quais as janelas de oportunidade se encontram abertas. Para isso, o trabalho dos empreendedores políticos, indivíduos dispostos a investir numa ideia, possui um papel central, unindo soluções a problemas, propostas a momentos políticos e eventos políticos a problemas. Enquanto o modelo de Kingdon fomentará a compreensão sobre a formação da agenda do novo Código Florestal, a teoria de Arnold subsidiará a análise das decisões tomadas pelos legisladores envolvidos.

Com essas questões centrais, o recorte do trabalho será a fase inicial da tramitação da matéria na Câmara dos Deputados, ou seja, o período desde a instalação da comissão especial até a aprovação no Plenário da Casa. Essa etapa foi suficiente para analisar as estratégias mais decisivas na reforma. Arnold (1990, p. 85), trabalhando com o caso norte-americano, assume que as comissões funcionam como o principal veículo para coletar e analisar informação. As comissões se especializam não apenas nas políticas, mas também na dinâmica delas. Elas encorajam grupos de interesse a testemunhar e submeter declarações, e seus burocratas e assessores a produzir cada vez mais estudos, o que faz com que as audiências e os relatórios das comissões geralmente representem o melhor guia da política. A Comissão Especial preencheu esse papel. As audiências públicas e o parecer da Comissão Especial foram capazes de revelar quais eram os interesses em jogo. Foram analisadas todas as atas e notas taquigráficas das reuniões promovidas, incluindo as audiências públicas e reuniões externas. $\mathrm{O}$ trabalho descritivo também se utilizou dos requerimentos apresentados na Comissão e das informações presentes no relatório gerado. Para complementar os dados, foram realizadas cinco entrevistas com participantes privilegiados do processo. Foram ouvidos dois consultores legislativos da Câmara dos Deputados, a secretária da comissão especial e dois assessores especiais do Ministério do Meio Ambiente.

Para que as diferentes formas de atuação das coalizões fossem mais bem compreendidas, o capítulo 2 destinou-se a levantar os principais estudos sobre a organização e representação dos segmentos envolvidos. Enquanto a "vocação agrária" do país está presente em suas raízes, a preocupação ambiental veio à tona apenas na segunda metade do século XX. Dessa forma, por ser um recorte mais contemporâneo, os trabalhos sobre a representação dos interesses ambientais são mais escassos. Por outro 
lado, a sobre-representação da classe agrária foi objeto recorrente das ciências sociais, com análises que abrangem desde o período imperial para explicar a concentração fundiária do país. Ambos os segmentos, entretanto, foram caracterizados por uma heterogeneidade interna. São formados por atores e interesses diversos. O que os distingue é a capacidade de unificar o comando nos momentos necessários para fortalecimento da classe.

Além disso, será visto que a bancada ruralista no Congresso Nacional tem se destacado por seu caráter suprapartidário e por sua capacidade de mobilização. Já o segmento ambientalista tem contado com uma atuação mais vinculada com o Poder Executivo. Foi dessa forma que durante o período pré-decisório da reforma florestal, as demandas ambientalistas obtiveram mais sucesso do que as ruralistas, visto as iniciativas governamentais terem sido no sentido de aumentar as garantias de preservação ambiental. Nesse cenário, como a reforma do Código Florestal centralizouse na agenda governamental? Essa questão será objeto do capítulo 3, que utilizará o modelo de múltiplos fluxos de Kingdon (2011 [1984]). Considerando que essa matéria sempre esteve entre as preocupações governamentais, busca-se responder como ela passou para a agenda decisória - definida por Kingdon como a lista de matérias prontas para uma decisão ativa.

A partir do momento em que a coalizão ruralista consegue transferir a iniciativa do debate para o Legislativo, a análise da atuação dos defensores e opositores da reforma será feita com os principais elementos da teoria de Arnold (1990). O capítulo 4 busca sintetizar esses elementos, destacando a definição que Arnold dá sobre a natureza da política, a percepção dos cidadãos e as estratégias mais utilizadas pelas lideranças das coalizões. No caso do código florestal, para que as lideranças ruralistas pudessem construir a coalizão, a elaboração de uma proposta politicamente rentável para os legisladores foi crucial. Concentrar benefícios e dispersar custos foram objetivos dos parlamentares para que através da política eles pudessem manter e até expandir a recompensa eleitoral.

Coube ao capítulo 5 a análise sobre as estratégias procedimentais, de persuasão e de modificação utilizadas pelas coalizões. Para isso, foram explorados os dados levantados sobre a Comissão Especial relacionada e as votações no Plenário da Casa. 
Além disso, também foi considerado se os membros dessa comissão atingiram os objetivos de recompensas eleitorais, partindo da premissa distributivista de Arnold. Visto que os trabalhos da comissão perpassaram por eleições federais, foram comparados os resultados das eleições de 2006 e de 2010 não só em termos de reeleição, mas também de financiamento eleitoral.

Quais as contribuições deste trabalho? Por tratar-se de um estudo de caso, algumas limitações são inerentes, como a impossibilidade de se generalizar as conclusões. Entretanto, o aprofundamento sobre essa reforma é capaz de apontar implicações relevantes do processo legislativo e da organização dos interesses, que em trabalhos quantitativos poderiam passar despercebidas. Quanto ao processo legislativo, pretende-se demonstrar o quanto a apropriação estratégica de recursos institucionais pode influenciar a sua definição e, consequentemente, o resultado da política. Utilizar a previsão regimental das Comissões Especiais, aumentar ou não a visibilidade do processo através de audiências públicas e votações em separado são alguns dos recursos que podem ser aproveitados pelas coalizões. Quanto à organização dos interesses, será destacada a relevância das escolhas das lideranças, como a definição da natureza da política, determinante na capacidade de construção da coalizão e mobilização de outros setores. Fora isso, pretende-se revelar a dinâmica da política florestal, sem qualquer julgamento de mérito, demonstrando a organização e forma de atuação dos interesses envolvidos em uma matéria que abrange uma das questões mais polêmicas do país. 


\section{Mapeando os Interesses Envolvidos}

As peculiaridades do Código Florestal começam pelo alcance de seu conteúdo. Uma política ambiental que dispõe sobre o uso de um bem público, na maioria das vezes, concentra custos e dispersa benefícios (ARAÚJO, 2007). É nessa regra que se enquadra a matéria florestal. Considerando-a superficialmente, seria natural a constatação de que o conflito se daria entre dois lados apenas: ruralistas e ambientalistas. De fato, os debates foram polarizados por esses setores. Contudo, a análise dos interesses defendidos na reforma florestal demonstra a existência de heterogeneidade entre esses segmentos. Além das divergências internas ${ }^{2}$, tanto a coalizão ruralista como a ambientalista envolveu, por exemplo, defensores da agricultura familiar, pequenos proprietários, trabalhadores rurais, comunidades tradicionais e atores que até então não tinham ligação com o tema. Como durante o processo de deliberação a união fez-se necessária para que houvesse uma soma de forças, as grandes lideranças buscaram construir suas coalizões, acomodando as representações menores. É nesse sentido que este trabalho seguirá com a denominação dos dois grupos, ressaltando que eles representaram diversos interesses.

Para mapear a formação dessas coalizões no Congresso Nacional, foi necessário buscar as caracterizações sobre as formas de agrupamento parlamentar. Além das divisões partidárias e estaduais, os parlamentares também se agrupam conforme os interesses que representam e defendem. Esses agrupamentos podem ser considerados como grupos de interesse formados por agentes públicos, usualmente denominados de bancadas. Além das bancadas, que não possuem requisitos formais para existirem, o Congresso é composto pelas frentes parlamentares. Conforme definição da Câmara dos Deputados $^{3}$, a frente parlamentar é uma associação suprapartidária destinada a aprimorar a legislação referente a um tema específico. Tomando como universo empírico os deputados federais do período de 2002 a 2006, o trabalho de Coradini

\footnotetext{
${ }^{2}$ A análise dos processos legislativos relacionados às políticas ambientais entre 1992 e 2006 de Araújo e Calmon (2011), com base no Advocacy Coalition Framework (ACF), demonstrou que a divisão tradicional entre ambientalistas e representantes do setor produtivo possui deficiências. Apontam quatro coalizões de defesa envolvidas na agenda verde (flora, fauna e biodiversidade): tecnocratas esclarecidos, socioambientalistas, desenvolvimentistas modernos e desenvolvimentistas tradicionais.

${ }^{3}$ Agência Câmara (2011).
} 
(2010) procurou demonstrar que as frentes não são o produto de alguma fragilidade partidária, mas de uma configuração específica dos modos de relacionamento entre a atuação de grupos de interesse e o espaço político. Sendo assim, a participação em frentes parlamentares está diretamente associada às atividades de expertise e de politização de interesses organizados.

Para que as frentes sejam registradas na Câmara, elas devem apresentar a adesão de no mínimo um terço dos integrantes do Legislativo ${ }^{4}$. Por essa exigência, as frentes possuem duas implicações: i) ao assinar a adesão à frente, o parlamentar declara pertencer ao grupo; e, (ii) para que seja possível a existência das frentes, os parlamentares assinam a adesão de várias delas sem de fato se preocuparem com o tema que elas representam, o que descaracteriza a relação do registro com a representação do parlamentar. Nesse sentido, nem todo parlamentar que se declara membro de alguma frente é de fato representante daquela causa. Em outras palavras, um membro da frente nem sempre faz parte da bancada relacionada.

No recorte da matéria florestal, há o predomínio de duas grandes frentes: a Frente Parlamentar Ambientalista e a Frente Parlamentar da Agropecuária. Conforme o gráfico 1, em 2011, dentre os 456 deputados adeptos a elas, 111 pertenciam a ambas. Por mais que a caracterização das frentes não seja suficiente para a constatação da real magnitude dos interesses representados, ela é necessária. Será visto que elas possuem estrutura definida e se relacionam com entidades do setor, sendo capazes de coordenar algumas atividades das coalizões.

\footnotetext{
${ }^{4}$ Ato 69 de 2005, da Mesa Diretora da Câmara dos Deputados.
} 


\section{Gráfico 1. Registro dos Deputados}

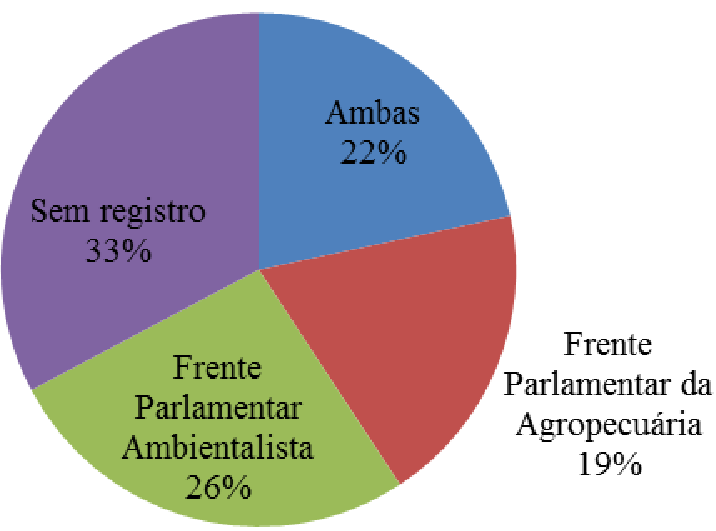

Enquanto as frentes são facilmente demarcadas pela exigência institucional, as bancadas não são. Vários são os critérios utilizados para definir quem é realmente de cada bancada. Quanto à temática ruralista, alguns dos critérios recentemente utilizados foram o de declaração de renda (INESC, 2001 e 2007) e o de declaração da defesa do pleito (DIAP, 2011). O primeiro trabalha com a ideia de interesse particular independente da atuação - quem possui alguma fonte de renda agrícola, e o segundo com a ideia de atuação independente de haver ou não interesse particular - quem assume sem constrangimento a defesa dos pleitos da bancada.

Sem ambição de propor uma nova caracterização para os grupos, este capítulo se propõe a levantar os principais dados sobre essas frentes e bancadas. Além disso, buscase sintetizar um histórico sobre o poder político das classes representadas, fundamental para a compreensão dos diferentes desempenhos na reforma florestal. No decorrer do texto, os termos bancada, frente e lideranças serão frequentemente utilizados. $\mathrm{O}$ primeiro fará referência à coalizão de parlamentares que já possuíam relação com o assunto e com que as lideranças poderiam contar. O segundo, ao grupo estruturado, que por muitas vezes definiu e organizou iniciativas relevantes no processo. E o terceiro, aos parlamentares que efetivamente atuaram por seus pleitos na tramitação do Código. É principalmente sobre essas lideranças que este estudo se voltará.

\subsection{Segmento Rural}


A presença dos interesses agrários nas arenas de poder foi um objeto recorrente nas ciências sociais. A associação do latifúndio ao passado colonial tem sido um dos elementos centrais desse recorte. Barcelos e Berriel (2009, p. 4) explicam a concentração fundiária a partir da relação entre o Estado e a defesa dos interesses da propriedade privada, calcada no imbricamento entre o público e o privado. Como exemplos dessa relação, citam as Capitanias Hereditárias ${ }^{5}$ e a Lei de Terras ${ }^{6}$. O primeiro exemplo é considerado como um fator que deu início à concentração fundiária no país, enquanto, posteriormente, a Lei de Terras viria afirmar a existência do latifúndio e impossibilitar que grande parte dos trabalhadores pudesse ter acesso ao território. Para os autores, o exemplo dessa Lei demonstra o poder histórico de pressão e influência dos grandes proprietários perante o Brasil.

O legado de Victor Nunes Leal (1948) consolida uma das primeiras análises sobre as relações de poder na República Velha, quando o sistema representativo do país se encontrava em desenvolvimento. Ressaltando a sobre-representação política das classes agrárias, o autor caracteriza o fenômeno do coronelismo como essencial na busca da compreensão da "vida política do interior do Brasil" ${ }^{7}$. Considerado como uma forma peculiar de manifestação do poder privado, tal fenômeno é definido como "resultado da superposição de formas desenvolvidas do regime representativo a uma estrutura econômica e social inadequada" ${ }^{8}$. A ampliação do sufrágio advinda com a República, para o autor, concebeu importância fundamental ao voto dos trabalhadores rurais, aumentando a influência política dos proprietários de terras. Assim, as características do coronelismo seriam estabelecidas a partir de relações de compromissos e troca de proveitos. Tais relações se dariam tanto no âmbito do governo com os chefes locais e desses com seus dependentes, tendo em vista os resultados eleitorais.

Mesmo com o fim da República Velha, que poderia ser interpretado como a saída dos latifundiários do controle do Estado, Barcelos e Berriel (2009, p. 7) apontam a

\footnotetext{
${ }^{5}$ Divisão do território brasileiro em 12 lotes (sesmarias), cedidos aos interessados em colonizar a terra, desde que fossem europeus e católicos.

${ }^{6}$ Lei 601 , de 18 de setembro de 1850, que dispõe sobre as terras devolutas do Império. Foi um instrumento para reconhecimento da posse das terras doadas pela Coroa Portuguesa, que estavam nas mãos de herdeiros.

${ }^{7}$ LEAL (1993), p. 19

${ }^{8}$ LEAL (1993), p. 20
} 
existência de um pacto político no governo Vargas com as oligarquias tradicionais rurais. Em troca de apoio ao governo federal, seus privilégios não foram ameaçados por políticas estatais que asseguraram direitos aos trabalhadores do campo. Dessa forma, a legislação trabalhista criada pelo governo Vargas não incluiu os trabalhadores rurais ${ }^{9}$.

A partir da ditadura militar, bem como na redemocratização, a pauta sobre a produção agrícola começou a mudar. Até a década de 1950, o crescimento da produção se dava pela extensão das áreas de terra cultivadas, sendo necessária a conquista de novos espaços, como o Cerrado. Entretanto, a política econômica do governo entre 1950 e 1970, que fomentou o processo de industrialização, favoreceu a indústria em detrimento da agricultura, o que reforçou o poder das cidades e acelerou o êxodo rural (ALVES et al, 2005, p. 39). Consequentemente, a modernização agrícola foi induzida pelo processo de industrialização. Além da influência da nova política econômica, Alves aponta outros três fatores determinantes no processo de modernização:

“(...) 1) crédito subsidiado, principalmente para a compra de fertilizantes e maquinaria; 2) grande extensão rural entre 1950 e 1970; 3) forte investimento em pesquisa e educação em ciências agrárias, com a criação da Embrapa (1973) e de cursos de pós-graduação." 10

A criação da Embrapa possui grande valia no decorrer deste trabalho, visto que, como será demonstrado posteriormente, a imagem de inovação e progresso que essa instituição obteve foi apropriada pela bancada ruralista. Conforme o histórico apresentado pela empresa $^{11}$ :

\footnotetext{
"Na década de 1970, a agricultura se intensificava no Brasil. O crescimento acelerado da população e da renda per capita, e a abertura para o mercado externo mostravam que, sem investimentos em ciências agrárias, o País não conseguiria reduzir o diferencial entre o crescimento da demanda e o da oferta de alimentos e fibras. (...) Nesse momento, os profissionais da extensão rural começaram a levantar a questão da falta de conhecimentos técnicos, gerados no País, para repasse aos agricultores. (...) Em 7 de dezembro de 1972, o então presidente da República, Emílio Garrastazu Médici, sancionou a Lei $\mathrm{n}^{\circ}$ 5.851, que autorizava o Poder Executivo a instituir empresa pública, sob a denominação de Empresa Brasileira de Pesquisa Agropecuária (Embrapa), vinculada ao Ministério da Agricultura. "
}

\footnotetext{
${ }^{9}$ O Decreto-Lei 5.452, de $1^{\circ}$ de maio de 1943, que aprovou a Consolidação das Leis do Trabalho (CLT), em seu Art. $7^{\circ}$, exclui a aplicação de seus preceitos aos empregados domésticos, trabalhadores rurais e funcionários públicos.

${ }^{10}$ ALVES et al (2005), p. 40

${ }^{11}$ Embrapa - Histórico disponível no portal eletrônico (2012).
} 
Segundo Mendonça (2005), durante esse processo da modernização agrícola, as entidades relacionadas às grandes propriedades fizeram-se presentes na esfera política através da retórica da "penalização da agricultura" diante de um suposto favorecimento estatal aos industriais. Porém, a partir dos anos 80, em lugar da vitimização, viria à tona o argumento da centralidade da agricultura na acumulação capitalista no país. Segundo as lideranças patronais, a produção agrícola era responsável pela geração de divisas para o país, por intermédio das exportações, sendo, dessa forma, responsável por parte substancial dos recursos utilizados no amortecimento da dívida externa brasileira.

Constata-se, então, que não existiu rompimento do pacto político histórico, mas o uso de diferentes estratégias para ocupar os espaços políticos possíveis. Houve apenas uma reorganização das forças hegemônicas na composição do Estado brasileiro. Dando continuidade a essa mudança de estratégia, estudos alegam que, a partir dos anos 1980, o discurso do patronato rural foi revitalizado, com uma nova ofensiva políticoideológica (BARCELOS e BERRIEL, 2009; BRUNO, 1997). Nas palavras de Barcelos e Berriel ${ }^{12}$ :

\footnotetext{
"A ideologia do moderno, contra-face do "velho" e "atrasado" mundo rural brasileiro, foi o fio condutor que catalisou uma nova realidade discursiva para a agricultura nacional como também projetou uma nova imagem identitárioterritorial para os "homens do campo", o "nós, produtores e empresários rurais". A modernização agrícola, a tecnificação da propriedade e a instituição de novos padrões de produção no campo, a partir da aliança agricultura-indústria - os complexos agroindustriais - foram as premissas fundantes deste novo pensamento."
}

O novo discurso foi marcado por uma tentativa de constituir uma identidade comum entre as classes agrárias, como se os interesses e necessidades dos trabalhadores, proprietários e empresários fossem os mesmos. Bruno (1997) e Barcelos e Berriel (2009) convergem sobre a perspectiva de que essa homogeneização da retórica procurou ocultar a luta de classes e a concentração fundiária, excluindo a reforma agrária do "novo" discurso. Qualquer tipo de enfrentamento era considerado como uma característica atrasada, visto que, para a elite agrária, o moderno padrão de desenvolvimento agrícola em curso não cedia mais espaço para a arcaica reforma agrária $^{13}$. Regina Bruno considera ainda que a tentativa de se configurar um bloco

\footnotetext{
${ }^{12}$ BARCELOS e BERRIEL (2009), p. 8.

${ }^{13}$ BRUNO (1997), p. 24.
} 
homogêneo buscava confundir os trabalhadores rurais e seus canais de representação, como se eles fossem unidos pela força e pelos interesses comuns do cenário agrícola, mecanismo pelo qual foi possível criar a falsa ideia de uniformidade do patronato agrário.

A ideia de um setor agrário uniforme tem sido refutada, enquanto um cenário de disputa de hegemonia interna tem sido retratado (BARCELOS e BERRIEL, 2009; BRUNO, 1997). O acesso ao crédito, concessão de benefícios, aquisição de terras, condições de mercado e recursos tecnológicos operam em condições diversificadas entre os grupos. E, ainda, para Bruno (1997), a nova retórica do grupo agro buscou apenas renovar os mecanismos de legitimação das estruturas de poder dos grandes proprietários e empresários rurais, fortalecendo as assimétricas relações políticas e sociais apoiadas na exploração de uma massa significativa de trabalhadores rurais. Entretanto, parece ser consensual que mesmo com disputa de hegemonia interna, as diversas organizações rurais defendem a necessidade de unificação do comando, e que esse seja politicamente homogêneo e presente nas instituições do Estado. Isso porque apesar de todas as divergências, em momentos de crise, todos se unem e se fortalecem enquanto classe. Em situações de fragilidade, os laços de complementaridade e ajuda saltam as diferenças.

Com esse novo discurso em construção, um grupo de parlamentares formou a Frente Ampla Ruralista - organização suprapartidária - para defender seus interesses na Assembleia Constituinte. Nesse período, as elites agrárias eram comandadas pela União Democrática Ruralista (UDR) ${ }^{14}$. Fundada em 1985 por Ronaldo Caiado - médico e empresário rural -, a UDR foi considerada uma das entidades mais radicais do Brasil (BARCELOS e BERRIEL, 2009; VIGNA; 2001 e 2007). Possuía o objetivo de opor-se aos dispositivos constitucionais sobre a reforma agrária e a democratização da terra.

"Os proprietários rurais sentiram a necessidade de se mobilizarem para conscientizar o Congresso Nacional a criar uma Legislação que assegurasse os direitos de propriedade. Na época, uma ala política de esquerda radical queria acabar com esse direito com objetivo explícito de se implantar um

\footnotetext{
${ }^{14}$ Conforme descrito no histórico disponível no portal da UDR: "A União Democrática Ruralista (UDR) é uma entidade de classe que se destina a reunir ruralistas e tem como princípio fundamental a preservação do direito de propriedade e a manutenção da ordem e respeito às leis do País. (...) A entidade teve sua primeira sede regional fundada em 1985, na cidade de Presidente Prudente - SP, e posteriormente no ano 1986, na cidade de Goiânia - GO, em seguida foi fundada a primeira UDR - Nacional, com sede em Brasília - DF."
} 
sistema comunista no Brasil. A reação dos ruralistas foi imediata, decidiram então fundar a União Democrática Ruralista - UDR. Foi a maior mobilização do setor já visto neste país. Com isso, conseguiu-se colocar na Constituição de 1988 a Lei que preserva os direitos de propriedade rural em terras produtivas. De 1994 a 1996 a UDR ficou desativada devido a desmobilização da classe, que sentiu-se mais segura após as conquistas na Constituinte e o afastamento dos riscos sobre o direito de propriedade. ${ }^{15}$

No início da década de 1990, devido a fatores como o impeachment do Governo Collor, a entrada da Confederação Nacional da Agricultura e Pecuária do Brasil (CNA) e da Sociedade Rural Brasileira (SRB) no cenário político, o fim da UDR, e a saída de Caiado do Congresso ${ }^{16}$, a base ruralista sofreu certa instabilidade, passando por modificações internas e externas. Em 1995 foi fundada, com ata assinada por deputados e senadores, a Frente Parlamentar da Agricultura. Em 2002, foi lançada a Frente Parlamentar de Apoio à Agropecuária, que em 2008 passou a ser denominada Frente Parlamentar da Agropecuária (FPA). Seu Estatuto (2008) descreve que a FPA é "uma entidade associativa que defende interesses comuns, constituída por representantes de todas as correntes de opinião política do Congresso Nacional e tem como objetivo estimular a ampliação de políticas públicas para o desenvolvimento do agronegócio nacional". No momento da instalação da Comissão Especial, em 2009, seu coordenador era o deputado Valdir Colatto (PMDB/SC) - engenheiro agrônomo. Em 2011, na 53 ${ }^{\mathrm{a}}$ legislatura, a frente possuía a adesão de 209 deputados e 14 senadores, totalizando 223 parlamentares $^{17}$.

Conforme disponibilizado pela Frente, suas entidades parceiras são estabelecidas como "entidades que participam de reuniões técnicas, nas quais são apresentadas e debatidas propostas e que dão subsídio e apoio às estratégias que norteiam o trabalho dos parlamentares". Totalizam 27 entidades ${ }^{18}$. Dentre elas encontram-se a Associação Brasileira do Agronegócio (ABAG), a Confederação Nacional da Agricultura (CNA), a Organização das Cooperativas do Brasil (OCB) e a União da Indústria da Cana-deAçúcar (UNICA). A CNA, além de ser uma entidade parceira, proporciona recursos

\footnotetext{
${ }^{15}$ Histórico disponível no portal eletrônico da UDR.

${ }^{16}$ Ronaldo Caiado (DEM/GO) foi deputado federal de 1991 a 1995 . Havia concorrido à Presidência da República em 1989 pelo PSD e também concorreu ao Governo do Estado de Goiás em 1994. Voltou à Câmara dos Deputados em 1999 e foi reeleito em 2003, 2007 e 2011.

${ }^{17}$ Dados obtidos no portal eletrônico da Frente Parlamentar da Agropecuária

${ }^{18}$ A lista de todas as entidades encontra-se no anexo 1.
} 
essenciais para os trabalhos da frente, como espaço para as reuniões, assessores e consultores dedicados a esse trabalho.

Entretanto, a totalidade de parlamentares que compõe a Frente Parlamentar da Agropecuária não corresponde à bancada mais atuante desse setor, ainda mais pelo fato de que parte desses parlamentares também pertence à Frente Parlamentar Ambientalista. Os trabalhos do INESC classificam a bancada ruralista conforme a declaração de fonte de renda disponível no site da Câmara dos Deputados (VIGNA; 2001 e 2007). Eles consideram como "membro potencial da bancada o deputado que declarou, entre suas principais fontes de renda, alguma forma de renda agrícola". Diante dessa classificação, na $53^{\text {a }}$ legislatura, a bancada contava com 116 parlamentares. Outra caracterização da bancada ruralista (DIAP, 2011), considera que 117 parlamentares a compunham na 53 legislatura. Diferentemente de Vigna, que buscou o interesse particular de cada deputado para determinar a bancada, o DIAP propôs a seguinte definição:

"O Departamento classifica como integrante da bancada ruralista aquele parlamentar que, mesmo não sendo proprietário rural ou da área de agronegócios, assume sem constrangimento a defesa dos pleitos da bancada, não apenas em plenários e nas comissões, mas em entrevistas à imprensa e nas manifestações de plenário." ${ }^{19}$

Enquanto Vigna se preocupou com a representação dos interesses particulares, sem verificar a defesa deles na prática, o DIAP se atentou à defesa do pleito independente do interesse particular. Assim, pode-se perceber certa complementariedade entre as duas classificações. Por mais que os critérios sejam diferentes, os números são praticamente coincidentes. A partir deles, pode-se estimar que, na $53^{\mathrm{a}}$ legislatura, aproximadamente um quarto da Câmara pertencia à bancada ruralista. Por mais que esse número por si só já aponte sua grandeza, Vigna destaca que a correlação de forças entre a bancada ruralista e as outras bancadas é ainda maior do que aparenta. Em suas palavras:

"O forte do grupo é o potencial para mobilizar um número de parlamentares bem maior que os diretamente envolvidos com a bancada. Assim, não é bem o número absoluto dos membros que promove sua força, mas a capacidade de

${ }^{19}$ DIAP (2011) 
mobilização que possui junto aos diversos partidos políticos e às bancadas estaduais, além de sua representação política federal." ${ }^{20}$

Essa capacidade de mobilização é o que confere à bancada algumas vitórias nas votações de seu interesse. Vigna (2007, p. 7) também aponta que, considerando o atual contexto político de déficit de disciplina partidária, num enfretamento entre $\mathrm{o}$ posicionamento do partido e dos ruralistas, é bem razoável que os interesses destes sejam consagrados. As aprovações da Lei de Biossegurança ${ }^{21}$, do relatório final da CPMI da Terra ${ }^{22}$ e, mais recentemente, a expressiva votação do Código Florestal, são exemplos de conquistas consideráveis que confirmariam esta hipótese.

A bancada ruralista conta com razoável representação em todas as regiões do país. Para Barcelos e Berriel (2009, p. 23), ela representa a reunião de distintas "territorialidades" presentes no patronato rural brasileiro, desde o empresário rural ao agropecuarista que compõem a arquitetura social do agronegócio. Por esse aspecto, a bancada possui a capacidade de defender seus interesses como demandas nacionais. Conforme o gráfico 2, observa-se uma concentração dos ruralistas na Região Nordeste, devido ao predomínio da histórica produção latifundiária nessa região. Entretanto, com o passar das legislaturas (1995/2007), é expressivo o crescimento da bancada nas outras regiões, principalmente na Região Centro-Oeste. De 2003 para 2007, o salto nessa região foi de $175 \%$.

\footnotetext{
${ }^{20}$ VIGNA (2007, p.6)

${ }^{21}$ A Lei de Biossegurança (Lei 11.105/05) foi aprovada pelo Congresso e sancionada com sete vetos pelo presidente Luiz Inácio Lula da Silva em março de 2005. A legislação disciplina o plantio e a comercialização de organismos geneticamente modificados (OGM), também conhecidos como produtos transgênicos, e autoriza o uso de células-tronco de embriões humanos para pesquisas.

${ }^{22}$ Em novembro de 2005, a Comissão Parlamentar Mista de Inquérito (CPMI) rejeitou o parecer do relator, deputado João Alfredo (PSOL/CE), e aprovou um voto em separado do deputado Abelardo Lupion (DEM/PR) - representante ruralista, que, segundo Sauer (2006), dificultou o avanço das políticas de reforma agrária e criminalizou a luta pela terra, materializada na atuação do Movimento dos Trabalhadores Rurais Sem Terra (MST).
} 


\section{Gráfico 2. Mapa Regional dos Ruralistas}

- $1995=1999 \approx 2003 \approx 2007$

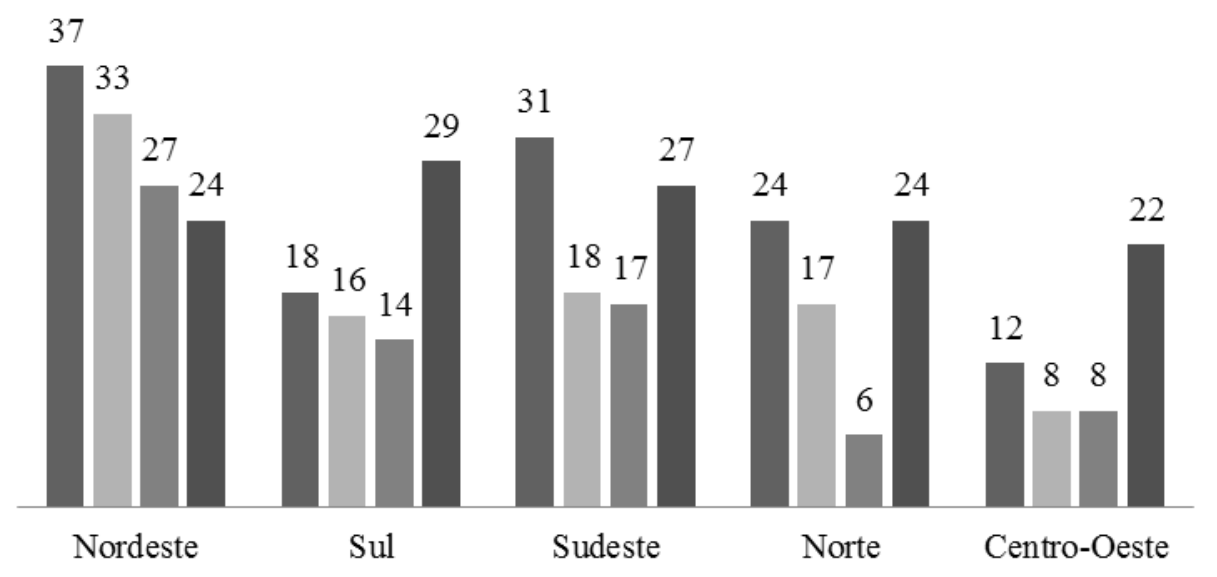

Fonte: Câmara dos Deputados. Elaboração: INESC (Vigna, 2007)

Barcelos e Berriel (2009, p. 21) também afirmam que a geografia da bancada pode ser compreendida através das distintas esferas de influência que compõem sua ação. $\mathrm{O}$ diferencial estratégico da bancada está na sua capacidade de administrar vários níveis de decisão, influenciando diversos atores. O domínio do sistema da Confederação da Agricultura e Pecuária do Brasil (CNA) é outro relevante fator. Conforme já mencionado, a unificação do comando é desejada para o fortalecimento da classe (BRUNO, 1997). Por mais que as relações sejam assimétricas, em momentos de crise, a união traz mais benefícios do que prejuízos. O instável início da década de 1990, em que UDR, CNA e SRB coexistiram, pode ter sido um aprendizado político para o segmento.

"O Sistema CNA funciona da seguinte forma: as Federações da Agricultura
trabalham nos Estados, os Sindicatos Rurais no âmbito dos municípios e a
Confederação da Agricultura e Pecuária do Brasil - CNA atua na defesa dos
interesses dos produtores rurais brasileiros junto ao Governo Federal, ao
Congresso Nacional e aos tribunais superiores do poder Judiciário, nos quais
dificilmente um produtor, sozinho, conseguiria obter respostas para as suas
demandas."

Quanto à caracterização dos membros da Frente Parlamentar da Agropecuária, os dados de Coradini (2010, p. 250 e 252) são bastante ilustrativos. No que tange às

${ }^{23}$ CNA (2012). 
principais ocupações profissionais dos deputados (2002/2006), a frente é composta majoritariamente por membros cuja carreira é composta pelo exercício de administração ou propriedade de empresas privadas e de ocupação de cargos públicos eletivos. Esse perfil de parlamentar preenche 52,63\% da frente ruralista, e apenas 7,99\% do total das cadeiras da Câmara. Além disso, a frente é a que possui a maior quantidade de membros vinculados a associações ou sindicatos de empresários: 30,91\% contra 9,99\% do universo total. Para completar a caracterização da frente, ela também é a que possui a maior quantidade de parlamentares com faixas patrimoniais superiores a um milhão de reais $(18,94 \%)$.

Entretanto, o fator mais relevante sobre o poder de articulação da bancada é o seu caráter suprapartidário. Todos os estudos citados afirmam que ela é capaz de se identificar com vários temas para garantir sua diversidade e sua habilidade de mobilizar o Congresso Nacional. Seu capital político não se faz apenas pelo número absoluto de seus parlamentares, mas pela possibilidade de construir novas relações institucionais com outros grupos de interesse. O gráfico 3 ilustra a disposição dos 116 ruralistas definidos pelo INESC - dentro dos partidos.

\section{Gráfico 3. Distribuição Partidária dos Ruralistas na}

Câmara dos Deputados (2007/2011)

- Bancada $\quad$ Ruralistas

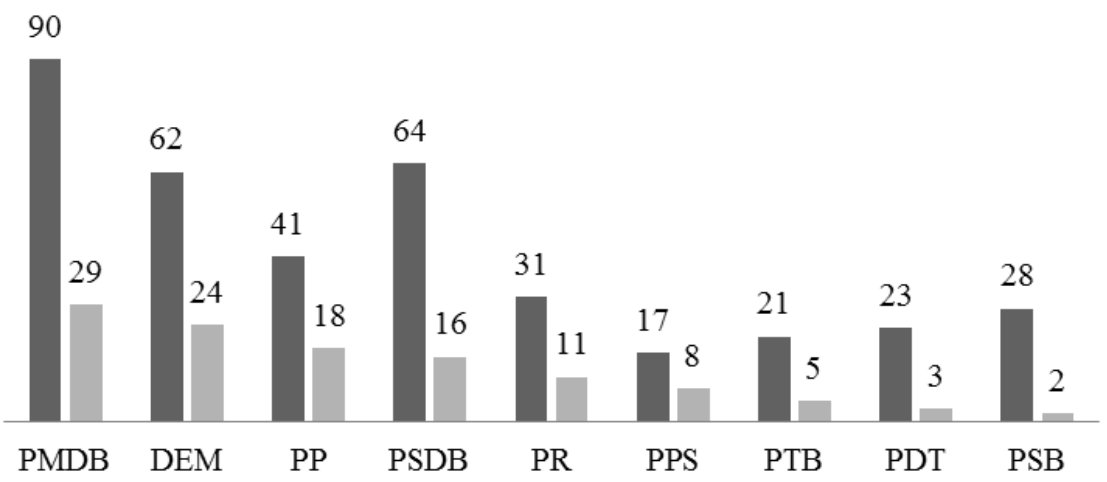

Fonte: Câmara dos Deputados. Elaboração: INESC (Vigna, 2007)

O gráfico indica que os membros estão inseridos em diversas posições do espectro político-partidário, desde partidos conservadores (PMDB, DEM e PP) até partidos de centro-esquerda (PDT e PSB). Porém, a concentração majoritária da 
bancada em partidos como PMDB, DEM e PP, juntamente com a ausência de representantes ruralistas em partidos como o PT e PCdoB, evidenciam sua tendência conservadora. Isso não significa que os dois lados não possam atuar juntos, visto que grande parte da bancada sempre esteve na base aliada do governo, seja ele PSDB ou PT (Vigna, 2007, p. 9). Barcelos e Berriel (2009, p. 17) consideram que o suprapartidarismo é uma estratégia, "um dispositivo de força política, um mecanismopoder de união e reciprocidade solidária com as frações de classe do poder agrofundiário no país".

Deve ficar claro que, conforme exposto anteriormente, essas "frações de classe" possuem interesses diversos. São constantes os conflitos entre trabalhadores e proprietários rurais e as condições de produção para os pequenos produtores são divergentes das condições dos grandes empresários. O segmento rural lida com a heterogeneidade. Mas, nos momentos necessários, cabe às lideranças de todas as frações encontrarem objetivos comuns para aumentar a expressividade da classe agrária e, assim, seu poder político. Foi nesse sentido que ocorreu o debate sobre as mudanças no Código Florestal. As diferenças entre os defensores da agricultura familiar, pequenos proprietários, cooperativas e até grandes latifundiários foram deixadas de lado, em certos momentos, para que juntos, esses setores conquistassem mudanças benéficas para o todo.

Além de criticada pelos estudiosos (BRUNO, 1997; VIGNA, 2001 e 2007), essa aparência de unificação também foi utilizada nos argumentos de oposição à reforma do Código Florestal. A afirmação de que os empresários rurais estavam se apropriando dos pequenos proprietários e dos agricultores familiar para defenderem seus interesses foi constantemente alegada. Mediante a agenda negativa da bancada ruralista, como a defesa da criminalização de movimentos sociais na CPMI da Terra e a oposição à PEC do trabalho escravo, os tradicionais líderes da coalizão como Ronaldo Caiado (DEM/GO), Abelardo Lupion (DEM/PR) e Valdir Colatto (PMDB/SC), precisariam de certo esforço para conseguir benevolência às suas demandas, mesmo no caso de elas serem compreensíveis e tecnicamente justificadas. Foi com essa condição que eles definiram e coordenaram as ações da bancada. Como desenvolvido nos próximos 
capítulos, eles procuraram centralizar as necessidades comuns entre os vários segmentos da classe para aumentar a legitimidade da proposta de mudança.

\subsection{Segmento Ambiental}

A legislação ambiental do país teve início em 1934, com o Código das Águas e o primeiro Código Florestal. Sua discussão foi retomada apenas na década de 1960, com o Código Florestal de 1965. A emergência da mobilização ambiental ganhou forças a partir de meados da década de 1970 (JACOBI, 2003). Nesse período, segundo Viola e Leis (1992), houve uma combinação de processos exógenos e endógenos. Entre os primeiros, destacam-se a Conferência de Estocolmo de 1972 e a volta de políticos exilados anistiados em 1979. Entre os segundos, o aumento da devastação amazônica e a superação do mito desenvolvimentista do período militar inicial (JACOBI, 2003, p. 2). Apenas em 1973 foi criada a Secretaria Especial do Meio Ambiente, no âmbito do Ministério do Interior.

Os grupos ambientais também se desenvolveram nesse período. Jacobi (2003, p.5) descreve que, concentrados em sua maioria na Região Sul-Sudeste, os grupos atuam principalmente com enfoque local, e em alguns casos desenvolvem campanhas de abrangência regional e mesmo nacional. Como exemplos, cita a campanha de denúncia contra o desmatamento na Amazônia em 1978, a luta contra a inundação de Sete Quedas no Rio Paraná (1979-1983), a luta contra a construção de usinas nucleares (1977-1985), a luta pela aprovação de leis do controle e de estímulo ao uso intensivo de agrotóxicos (1982-1985).

A repercussão dessas campanhas juntamente com a extensão das queimadas na Amazônia e no Cerrado e a eliminação quase total da Mata Atlântica estimulou a articulação com ONGs ambientalistas europeias e norte-americanas. Além disso, a deterioração da qualidade ambiental nos grandes centros urbanos, como o caso de Cubatão, ganhou espaço na mídia nacional e internacional. Entretanto, o ator afirma que havia pouca aderência ao discurso ambiental na sociedade. Um dos fatores para isso se refere ao isolamento das organizações ambientalistas dos outros movimentos sociais. Para Jacobi (2003, p.8), o discurso que priorizava a necessidade de garantir a qualidade ambiental ignorava as demais demandas sociais. 
Nesse contexto foi fundado o Partido Verde (PV), em 17 de janeiro de 1986. Contra a propagação de usinas nucleares no Brasil, o partido uniu grupos de ecologistas, artistas e intelectuais, sendo que boa parte desses fundadores havia voltado do exílio durante o regime militar. Jacobi (2003) destaca a figura de Fernando Gabeira que adquiriu ampla visibilidade pública e iniciou a organização do PV no Brasil ${ }^{24}$. Nas eleições para a Assembleia Constituinte, dos 20 candidatos ambientalistas que concorreram, apenas Fábio Feldmann ${ }^{25}$ foi eleito (Viola e Vieira, 1992). Entretanto, Jacobi (2003, p. 10) aponta que:

\begin{abstract}
"Apesar da eleição de um único candidato defendendo uma proposta estritamente ambientalista, a maior receptividade da temática ambiental na esfera política possibilitou a formação na Assembleia Constituinte de 1988 de uma Frente Parlamentar Verde (15\% dos deputados), que logrou transformar a legislação ambiental brasileira em uma das mais modernas do mundo, em termos de proteção ambiental. Destacam-se o zoneamento ambiental, a exigência de apresentação de Estudos de Impactos Ambientais, e que sejam discutidos em audiências públicas e a introdução de diversas penalidades para agentes agressores do meio ambiente."
\end{abstract}

A partir de então, grupos ambientalistas passaram a influenciar diversos movimentos sociais, os quais incorporaram gradativamente a proteção ambiental como outra dimensão do trabalho (Jacobi, 2003, p. 12). O socioambientalismo se expandiu entre organizações não governamentais e movimentos sociais, que apontavam a necessidade de se pensar modelos sustentáveis, vinculando a questão ambiental à questão social. Essa nova concepção do ambientalismo se fortaleceu durante a preparação da Rio- $92^{26}$, com a criação do Fórum Brasileiro de Ongs e Movimentos Sociais para o Meio Ambiente e Desenvolvimento (FBOMS).

Com essa mobilização, a discussão sobre a temática ambiental ganhou espaço no Congresso Nacional. Conforme Araújo e Calmon (2011), estiveram na pauta dos debates legislativos, entre 1992 e 2010, as leis do Sistema Nacional de Unidades de Conservação (Snuc), da Mata Atlântica, de Gestão das Florestas Públicas, de Crimes Ambientais, da Política Nacional sobre Mudança do Clima e da Política Nacional de Resíduos Sólidos, além do Código Florestal e das normas de acesso aos recursos

\footnotetext{
${ }^{24} \mathrm{Na} 54^{\mathrm{a}}$ legislatura, o PV conta com 1 senador e 10 deputados federais.

${ }^{25}$ Foi eleito pelo PMDB, mas já em 1988 filiou-se ao PSDB.

${ }^{26}$ Conferência das Nações Unidas sobre o Meio Ambiente e Desenvolvimento, realizada entre os dias 3 e 14 de junho de 1992, na cidade do Rio de Janeiro. Dentre os principais resultados, destacam-se as convenções de biodiversidade e de mudanças climáticas e a assinatura da Agenda 21.
} 
genéticos. Ao avaliarem a atuação das entidades civis nesses processos, a partir das audiências públicas e outras reuniões abertas que ocorreram no Congresso, entre 1992 e 2006, destacam a participação das seguintes entidades: Amigos da Terra; Fórum Brasileiro de Organizações Não-Governamentais e Movimentos Sociais para o Meio Ambiente e o Desenvolvimento (FBOMS); Greenpeace; Instituto Socioambiental (ISA); Rede de Organizações Não-Governamentais da Mata Atlântica (Rede Mata Atlântica); SOS Mata Atlântica; World Wildlife Fund (WWF); Instituto de Pesquisa Ambiental da Amazônia (Ipam); Instituto do Homem e Meio Ambiente da Amazônia (Imazon); entre outras.

Os autores também demonstram que em cada um dos processos legislativos relacionados houve um jogo peculiar de forças entre os atores envolvidos (ARAÚJO e CALMON, 2011, p. 15). De um modo geral, destacam que a integração de um conjunto de organizações ambientalistas com o Ministério do Meio Ambiente se intensificou com a gestão de Marina Silva na pasta (2003/2008). Nesse período, alguns líderes das entidades civis foram indicados para importantes posições no governo, o que, segundo Araújo e Calmon, parece ter atenuado as críticas feitas à atuação do Executivo na área ambiental (2011, p.7). Com isso, a participação das organizações não-governamentais marcou-se pelo vínculo direto com o Poder Executivo.

Já no Congresso, a mobilização ambiental se intensificou com o registro da Frente Parlamentar Ambientalista para o Desenvolvimento Sustentável e da Bancada da Amazônia Legal, ambas em 1998 (VOGEL, 2005, p. 9). A primeira foi novamente registrada em 2003 e 2007. O Estatuto (2007) da Frente Parlamentar Ambientalista afirma que essa foi "instituída para acompanhar os processos legislativos e outras atividades do Congresso Nacional que apresentem relação, direta ou indireta, com a questão ambiental, bem como para atuar, conjuntamente com a sociedade civil, no apoio a políticas públicas, programas e ações governamentais e não governamentais com o objetivo de alcançar padrões sustentáveis de desenvolvimento". Quando a Comissão Especial do Código Florestal foi instalada, o deputado Sarney Filho (PV/MA) ministro do Meio Ambiente de 1999 até 2002 - era o coordenador da frente e ainda permanece no cargo. Em 2011, possuía a adesão de 247 deputados e 21 senadores, 
totalizando 268 parlamentares ${ }^{27}$. São 26 entidades parceiras que a frente possui ${ }^{28}$. Entre elas, encontram-se o FBOMS, a Federação das Indústrias do Estado de São Paulo (FIESP), o Greenpeace Brasil, o ISA e o WWF Brasil. As entidades SOS Mata Atlântica e o IPAM se destacam ao fazerem parte do Conselho Consultivo da Frente, juntamente com os parlamentares.

Uma das características do movimento ambientalista que merece destaque é a dificuldade de lidar com sua diversidade de atores e práticas. Conforme apontado por Jacobi (2003, p. 31), as reuniões nacionais dos ambientalistas se reduziram significativamente, principalmente em virtude da falta de recursos. Um exemplo disso é que as reuniões do FBOMS caíram de uma média de uma a cada quatro meses entre 1990 e 1992, para uma média de uma a cada 15 meses desde 1992. Além disso, muitos movimentos ainda trabalham sobre causas específicas, localizadas. Dessa forma, a expressividade do setor é mais fragmentada e, na ausência de um comando unificado, o poder político da classe torna-se relativo.

Isso não significa, porém, que os interesses ambientais não tenham obtido êxito nas esferas públicas. Se no Congresso a representação rural encontra-se mais enraizada e capaz de mobilizar outros setores, no Poder Executivo, como demonstrado, desde a gestão Marina Silva, os representantes dos principais movimentos ambientais estão fazendo presença, o que tem condicionado a forma de ação desse segmento. As leis de Gestão das Florestas Públicas e de Crimes Ambientais, por exemplo, são conquistas ambientais de autoria do Executivo. No caso da reforma do Código Florestal, caberia aos ambientalistas evitarem que o debate fosse dominado pelo Legislativo. Entretanto, conforme visto no próximo capítulo, as lideranças ruralistas souberam aproveitar o momento político pré-eleitoral e utilizar prerrogativas institucionais para definirem quando e como a reforma começaria.

\subsection{Qual era o conflito?}

27 Dados obtidos no portal eletrônico da Frente Parlamentar Ambientalista, disponível nas referências bibliográficas.

28 A lista com todas as entidades encontra-se no anexo 2. 
As normas de preservação e conservação ambiental estão dispersas na Constituição Federal (art. 225), em vários diplomas legais e outros instrumentos normativos. Entretanto, mesmo com um aparato jurídico considerado como um dos mais avançados do mundo em termos de proteção ambiental, o cenário de devastação ambiental não foi controlado. Segundo dados do Instituto Nacional de Pesquisa Espaciais (INPE), as taxas de desmatamento anuais na Amazônia oscilaram de 1988 a 2008 entre 10.000 e $30.000 \mathrm{~km}^{2}$, ao mesmo tempo em que as áreas remanescentes da Mata Atlântica eram mínimas.

Por mais que desde 1998 houvesse a Lei de Crimes Ambientais, que trata de sanções penais e administrativas para condutas lesivas ao meio ambiente, a regulamentação dispondo sobre as infrações e multas só foi estabelecida em 2008, pelo Decreto 6.514. Dessa forma, até 2008, as atividades prejudiciais ao meio ambiente não estavam sendo efetivamente punidas. Ao estipular multas no valor entre 50 e 50 milhões de reais às infrações ambientais, como cortar árvores sem autorização e degradar florestas, esse decreto buscaria, finalmente, tornar efetiva a legislação ambiental.

Foi nessa situação que a bancada ruralista teve que se mobilizar. Por mais que a questão pontual se resolvesse com a edição de outro decreto prorrogando o prazo de adequação - o que de fato veio a ocorrer - ou até revogando as medidas punitivas, as lideranças buscaram mais. Provavelmente porque se sentiriam juridicamente mais seguras com mudanças na própria lei que dispõe sobre a proteção da vegetação e exploração florestal. Ao considerarem que a legislação em vigor estava muito distante da realidade do país, perdendo a função de proteger o meio ambiente com condições efetivas, alguns membros da Frente da Agropecuária apresentaram a proposta do Código Ambiental Brasileiro, que revogaria o antigo Código Florestal.

"O estabelecimento de parâmetros, porcentagens e metragens de forma generalizada em um país de proporções continentais foi o início de uma antipolítica ambiental. Na tentativa de reprimir os avanços, os diplomas foram se multiplicando vertiginosa e desordenadamente com regras cada vez mais rígidas e o que se conseguiu foi punir aqueles que protegeram o meio ambiente com o engessamento econômico. Porém, onde há miséria, não há condição de proteção dos recursos naturais." ${ }^{29}$

${ }^{29}$ PL 5367/2009, p. 43. 
Dessa forma, pleitearam mudanças no sentido de "flexibilizar" as definições de áreas de preservação permanente e reserva legal. Para eles, não haveria como uma mesma regra valer para todos os lugares do país. Defenderam, então, que a lei contemplasse apenas pontos genéricos e deixasse a cada estado definir os conceitos específicos. Para defender esse pleito, utilizaram-se do art. 24 da Constituição Federal.

\begin{abstract}
"Além disto, as normas vigentes ainda não contemplam mandamentos constitucionais mesmo duas décadas depois de sua promulgação, pois os principais diplomas da legislação ambiental, que são a Lei da Política Nacional de Meio Ambiente 6938/81 e o Código Florestal, 4771/65 são anteriores à Constituição Federal. Ao contrário das Constituições anteriores em que cabia apenas à União legislar sobre florestas, caça e pesca, nossa "Constituição Cidadã" prestigiou e consolidou o sistema federativo e estabeleceu no art. 24 que seria de competência da União estabelecer apenas e tão somente normas gerais a respeito de meio ambiente e que aos Estados caberia legislar sobre suas peculiaridades. ${ }^{30}$
\end{abstract}

A descentralização prevista no artigo 24 não é de fácil aplicação, visto sua imprecisão. Além disso, os ambientalistas alegavam que o risco de se piorar a situação da conservação ambiental do país seria muito grande ao se passar esse poder aos estados. E, para eles, o problema não estava na legislação, mas na ausência de aplicação. Nesse ponto, os ruralistas também pleitearam a anistia das atividades consideradas lesivas ao meio ambiente praticadas até antes da edição do Decreto 6.514. Alegavam que, além da perda da produtividade ao destinarem parte das propriedades à conservação ambiental, os custos para recuperar a vegetação eram muito altos. Defenderam, então, que ao invés de punir com multas exorbitantes os proprietários irregulares, o governo deveria propiciar auxílios e incentivos para que eles se adaptassem, como o pagamento por serviços ambientais. Justificavam que os benefícios de um meio ambiente preservado são coletivos, de toda a sociedade, enquanto o custo para mantê-lo seria do setor rural.

De forma sintética, esses foram os pontos mais conflituosos da reforma. Os ambientalistas desejavam a manutenção da legislação e a aplicação das punições administrativas. Em contrapartida, a flexibilização das regras de preservação e meios para que elas pudessem ser efetuadas foram os maiores anseios dos ruralistas.

\footnotetext{
${ }^{30}$ PL 5367/2009, p. 43.
} 


\section{Construção da Agenda}

Alterada por dez leis e uma medida provisória, a Lei 4.771 de 1965 - antigo Código Florestal - foi regulamentada por treze decretos ${ }^{31}$ durante sua vigência. Após tramitar por quase 13 anos no Congresso Nacional, a reforma dessa legislação originou a Lei 12.651 de 2012, proveniente da Câmara dos Deputados. Parcialmente vetada pela Presidência da República, a lei contou com a edição de uma medida provisória alterando seus pontos mais polêmicos.

Neste capítulo pretende-se compreender como essa reforma entrou na agenda e como se iniciou o processo de defesa das alternativas. A partir do histórico das reformas da matéria florestal, entende-se que ela sempre esteve na pauta governamental, como um processo de mudança permanente, porém não como prioridade. Dessa forma, a questão a ser tratada refere-se ao momento em que a matéria passou a ser prioridade e, então, teve que ser efetivamente debatida. Para isso, serão utilizados os elementos centrais do modelo de multiple streams desenvolvido por Kingdon (2011 [1984]). O conceito de agenda por ele definido refere-se à lista de matérias ou problemas aos quais o governo e as pessoas fora do governo, mas próximas a ele, estão prestando atenção em um determinado momento. Dentro disso, distingue-se a agenda governamental da agenda decisória. A primeira aborda a lista de assuntos que estão recebendo atenção e, a segunda, a lista de matérias que estão prontas para uma decisão ativa, sendo que cada uma possui processo e atores influentes próprios.

A matéria do Código Florestal sempre obteve atenção do governo e dos outros atores. Entretanto, após a edição da MP 2.166 de 2001, a atuação do governo se deu de forma mais esparsa e pontual, através de decretos e resoluções, satisfazendo em alguma medida os anseios ambientalistas contra uma reforma que alterasse mais fortemente $o$ status quo. Apenas com a instalação da Comissão Especial na Câmara dos Deputados, governo e demais atores necessitaram tornar a matéria um dos principais problemas de suas agendas, mobilizando recursos para tomar decisões de maior repercussão do que alterações pontuais. Nesse ponto, busca-se compreender como surgiu a necessidade de uma decisão oficial sobre o Código e quais eram as expectativas do momento. Em

\footnotetext{
31 Dados retirados da busca de legislação no Portal do Planalto.
} 
outras palavras, este estudo espera ilustrar a passagem da agenda governamental para a decisória definidas por Kingdon.

\subsection{Modelo de Multiple Streams}

A literatura científica sobre a formação da agenda tem seu ponto inicial com Charles Lindblom ${ }^{32}$. Em sua obra, a ideia de que as políticas públicas surgem em respostas racionais a problemas é refutada. Com uma percepção de racionalidade limitada, o contexto da decisão é caracterizado por elevada incerteza e informação escassa. Assim, contra a concepção idealizada da construção da agenda, Lindblom aponta a aquisição de conhecimento, condições políticas e o debate em torno de soluções como fatores condicionantes do processo, sugerindo uma formulação incremental.

Nessa nova perspectiva, a formação da agenda governamental foi objeto de vários modelos. Essa área de estudos se desenvolveu e consolidou em uma era dominada pelo pluralismo. No entanto, esses trabalhos tenderam, mesmo antes do neoinstitucionalismo, a incorporar as ideias e a construção dos problemas sociais. Nessa linha, além do modelo de Multiple Streams, outros dois modelos se destacam: a teoria do Equilíbrio Pontuado (Punctuated-Equilibrium Theory) desenvolvida por Frank R. Baumgartner e Bryan D. Jones (1993) e o Advocacy Coalition Framework (ACF), de Paul Sabatier (1988) . De forma sintética, o primeiro procura explicar de que forma se alternam momentos de estabilidade e de rápida mudança, tomando como base dois eixos; as estruturas institucionais e o processo de construção da agenda. O segundo (ACF) foca o entendimento da dinâmica e escopo de subsistemas das políticas, demonstrando como seus participantes negociam suas convicções para deslocá-las à agenda governamental.

Todos eles partem da premissa de que o processo é altamente competitivo e que raramente questões entram na agenda. Entretanto, cada modelo privilegiou um elemento, sejam as instituições ou as comunidades políticas, por exemplo, como atores principais na formação da agenda. Por destacar a influência dos empreendedores

\footnotetext{
${ }^{32}$ The Science of Muddling Through, (1959).
} 
políticos e a mudança de ciclos políticos, o legado de Kingdon contribuiu para evidenciar alguns elementos relevantes para o entendimento da reforma do Código Florestal.

De forma sintética, Kingdon considera as políticas públicas como um conjunto formado por quatro processos: (i) o estabelecimento de uma agenda (agenda-setting); (ii) a consideração das alternativas para a formulação das políticas (policy formulation); (iii) a escolha dentre o conjunto de alternativas disponíveis; e, (iv) a implementação da decisão. O modelo de multiple streams preocupa-se com os dois primeiros processos, conhecidos como estágios pré-decisórios. Tendo em vista a compreensão das mudanças na agenda, Kingdon adapta a ideia sobre os fluxos de uma "anarquia organizada" desenvolvida pelo modelo do garbage can $^{33}$, enfatizando mais a ideia do organizado do que da anarquia, visto que desenvolve as estruturas do processo. Afirma, assim, que existem fluxos separados e com vidas próprias que perpassam as organizações e que são acoplados em momentos críticos. Quando esta união ocorre se produzem as maiores mudanças na agenda (p. 87).

Kingdon apresenta três tipos comuns de processos na construção da agenda do governo: problemas, soluções e político. Uma de suas maiores percepções é que as questões presentes na agenda governamental não são geradas aos pares. Problemas e soluções não são gerados ao mesmo tempo.

Quanto ao reconhecimento dos problemas, o modelo compreende que são construções sociais, envolvendo interpretação (p. 109). Assim, do ponto de vista da estratégia política, a definição do problema é fundamental, visto não bastar apenas a existência objetiva de uma questão ou problema. Esse fluxo abrange indicadores, eventos, símbolos ou feedbacks interpretados como construções sociais. Os elementos apresentados sinalizam questões específicas, sem, no entanto, serem automaticamente transformados em problemas a serem enfrentados. Para que se tornem problemas no interior de uma agenda, necessitam de acompanhamento de percepções pré-existentes as

\footnotetext{
${ }^{33}$ Desenvolvido por Cohen, March e Olsen (1972), o modelo da "lata do lixo" estipula que as organizações são formas anárquicas que possuem três propriedades: preferências problemáticas, tecnologia incerta e participação fluida. As escolhas compõem uma lata de lixo onde os participantes clocam vários tipos de problemas e soluções à medida que estes aparecem.
} 
quais possam ser reforçadas por tais elementos ou de combinação com outros eventos (p. 113).

Após definir o fluxo dos problemas, Kingdon apresenta o fluxo das alternativas, formado por um conjunto de soluções disponíveis para os problemas. Abrange, assim, o processo pelo qual as propostas são geradas, debatidas, rejeitadas e aprovadas. Centrais a esse processo são as comunidades geradoras de alternativas (p. 117), compostas por assessores parlamentares, acadêmicos, especialistas, funcionários públicos, pesquisadores, entre outros, que compartilham uma preocupação em relação a uma determinada área. A difusão das ideias é tida como um processo no qual os indivíduos que as defendem procuram levá-las a diferentes espaços e eventos, na tentativa de sensibilizar não apenas as comunidades de políticas, mas também o público em geral, vinculando audiência às propostas e construindo progressivamente sua aceitação.

Independente dos problemas e das alternativas, o fluxo da política ocorre conforme suas próprias dinâmicas e regras. Diferentemente do fluxo de alternativas, em que o consenso é construído com base na persuasão e difusão das ideias, no fluxo político, as coalizões são construídas a partir de um processo de negociação. Nesse processo, Kingdon define três elementos influentes sobre a agenda governamental. $\mathrm{O}$ primeiro, chamado de "clima" ou "humor" nacional (p. 146), é caracterizado por uma situação na qual diversas pessoas compartilham as mesmas questões durante um determinado período de tempo. Neste período, algumas ideias podem ser mais bem desenvolvidas e aceitas, enquanto outras não chegam à agenda e são descartadas, como mudanças da opinião pública. O segundo fator do fluxo político é composto pelas forças políticas organizadas, exercidas principalmente pelos grupos de pressão (p. 150). O apoio ou a oposição dessas forças a uma determinada questão sinaliza consenso ou conflito numa arena política, permitindo aos formuladores de políticas avaliarem se o ambiente é propício ou não a uma proposta. O terceiro elemento a afetar a agenda são as mudanças dentro do próprio governo (p. 153). Esses acontecimentos podem exercer grande influência sobre a agenda governamental ao desencadearem mudanças que potencializam a introdução de novos itens na agenda, ao mesmo tempo em que podem também bloquear a entrada ou restringir a permanência de outras questões. $\mathrm{O}$ início de 
um novo governo é, segundo Kingdon, o momento mais propício para mudanças na agenda.

Outro componente fundamental do modelo refere-se aos empreendedores de políticas (p. 179). O autor destaca a importância de indivíduos que, tal como empreendedores de negócios, estão dispostos a investir numa ideia, podendo estar no governo, ou fora dele, como, por exemplo, em grupos de interesse, na comunidade acadêmica e na mídia. Para ele, os empreendedores desempenham um papel central, unindo soluções a problemas; propostas a momentos políticos; eventos políticos a problemas. Sem um empreendedor, a ligação entre os fluxos pode não acontecer, dificultando a promoção de mudanças na agenda.

Para que uma mudança ocorra, é necessário que haja um momento de convergência entre os três fluxos decisórios (p. 172). As circunstâncias que possibilitam a convergência dos fluxos são denominadas por Kingdon como janelas de oportunidades (p. 166). O autor destaca que essas circunstâncias são influenciadas, sobretudo, pelo fluxo de problemas e pelo fluxo político. Em síntese, uma oportunidade para a mudança surge quando um novo problema consegue atrair a atenção do governo por meio de indicadores, eventos, entre outros, ou quando mudanças são introduzidas na dinâmica política, principalmente mudanças no clima nacional e mudanças dentro do governo.

Por outro lado, a rede de soluções, embora não exerça influência sobre a formação da agenda governamental, é fundamental para que uma questão já presente nessa agenda tenha acesso à agenda decisória - lista de matérias prestes a ter decisões oficiais, como uma promulgação legislativa ou uma escolha presidencial (p. 202). Conforme Kingdon, dois elementos são centrais nessa passagem: (1) as alternativas são geradas e selecionadas no fluxo das soluções; e, (2) há envolvimento de participantes "escondidos" - especialistas da área específica da política (p. 200).

As comunidades de especialistas são formadas em partes por um grupo de participantes escondidos. Entre eles estão os acadêmicos, pesquisadores, consultores, burocratas, assessores parlamentares e analistas que trabalham para grupos de interesse. Essas comunidades são especializadas em temas, como saúde, meio ambiente e transportes, sendo que umas são mais fragmentadas do que outras. As ideias surgem 
nessas comunidades e são propostas de diversas formas: discursos, projetos de lei, audiências públicas, entre outras.

A geração de alternativas é vista como um processo de seleção, em que critérios são impostos para selecionar ou descartar algumas ideias. Esses critérios incluem viabilidade técnica, coerência com os valores dos membros de cada comunidade e antecipação de restrições, como orçamento e receptividade pública. O processo de aceitação e negociação das propostas é longo e condicionado pela atuação dos empreendedores políticos, que levam suas propostas para consideração em vários espaços e de diversas formas. A probabilidade de um item ter acesso à agenda decisória aumenta se o problema, a proposta e a receptividade estiverem ligados em um único "pacote" (p. 202).

Com essa breve descrição do modelo de multiple streams, pretende-se, agora, aplicar seus elementos centrais ao caso do Código Florestal. Para isso, o modelo foi utilizado como uma ferramenta para dispor sobre a trajetória de reformas dessa matéria, nos fluxos de problemas, soluções e político. A principal questão é responder como o tema que sempre esteve presente na agenda governamental, ainda que nem sempre prioritário, teve acesso à agenda decisória.

\subsection{Fluxo dos Problemas}

A percepção de que a matéria florestal sempre esteve em permanente mudança pode ser constatada com o histórico de reformas da legislação. O antigo Código Florestal (Lei 4.771 de 1965) foi enviado ao Congresso Nacional em 1950, pelo governo Gaspar Dutra (Projeto Daniel de Carvalho), em substituição ao que vigia desde 1934, sancionado por Getúlio Vargas ${ }^{34}$. Mas tramitou por mais de uma década sem resultados concretos. Apenas em 1962 foi formado um grupo de trabalho, composto por seis especialistas, para reformar a proposta do "novo" código - que foi finalmente sancionado em 1965 através da Lei 4.771. Assim, já na sua formulação inicial, foram necessários quase 15 anos para que o texto pudesse ser aprovado, indicando em parte a

\footnotetext{
${ }^{34}$ Decreto $\mathrm{n}^{\circ} 23.793$ de 1934, que definia algumas medidas de proteção das florestas, entre elas a manutenção de $25 \%$ da cobertura vegetal nativa em propriedades privadas, conhecida como a "quarta parte".
} 
dificuldade de constituir política sobre essa questão mesmo em um momento de pressão muito menos intensa, se é que existente, de movimentos ambientalistas. Desde que entrou em vigor, a legislação foi alvo de discussão e reformas. Nas palavras do relatório apresentado na Comissão Especial do deputado Aldo Rebelo (PCdoB/SP):

"Examinando-se o Código de 1965, percebe-se que os problemas não devem
ser buscados nos seus princípios, mas sim nas absurdas alterações que sofreu
em anos recentes, que o tornaram uma caricatura de si próprio, um arremedo
de seu espírito original. Bem ou mal, o Código Florestal votado em 1965, em
pleno governo militar, foi submetido ao crivo de juristas de espírito público e
à aprovação do Congresso Nacional. É paradoxal que em plena democracia
ele tenha sido completamente alterado por decretos, portarias, resoluções,
instruções normativas e até por uma medida provisória que virou lei sem
nunca ter sido votada. É verdade ainda que o próprio Estado foi o primeiro a
negar a aplicação da lei, a desrespeitá-la, fomentando o seu
descumprimento."35

O relatório se refere, conforme exposto, às alterações sofridas pela lei de 1965, sendo que muitas delas foram obtidas sem o devido processo legislativo. Nesse conjunto, destaca-se a Medida Provisória (MP) 2.166-67 de 2001 do Governo Fernando Henrique Cardoso que, entre outras mudanças, aumentou a área de reserva legal das propriedades rurais na Amazônia Legal, de 50\% para $80 \%$ em cada propriedade. Tal MP manteve-se em vigor por força da Emenda Constitucional (EC) 32 de $2001^{36}$. É válido ressaltar que a MP vinha sendo reeditada desde 1996. Sua última edição ocorreu 20 dias após a aprovação final da EC 32, a tempo de ser incluída no conjunto de medidas que continuariam em vigor. Assim, como não houve deliberação definitiva posterior pelo Congresso Nacional, matérias relevantes do Código permaneceram disciplinadas pela MP por mais de uma década até a reforma atual. Entretanto, a falta de deliberação definitiva sobre a matéria não ocorreu devido à ausência de iniciativas legislativas, visto que desde o envio da MP até a instalação da Comissão Especial, haviam sido apresentados 81 projetos de lei sobre o assunto $^{37}$ e nenhum deles foi transformado em norma jurídica.

\footnotetext{
${ }^{35}$ REBELO (2010), p. 4.

${ }^{36}$ A Emenda Constitucional 32 de 2001 estabeleceu que as medidas provisórias editadas em data anterior à de sua publicação (12/09/2001) continuariam em vigor até que medida provisória ulterior as revogassem explicitamente ou até deliberação definitiva do Congresso Nacional.

37 Levantamento próprio feito no Portal da Câmara dos Deputados. A busca foi feita com os termos "código florestal", "área de preservação permanente" e "reserva legal" para projetos de lei apresentados entre 24/08/2001 - data do envio da MP, e 08/09/2009 - data da instalação da Comissão Especial.
} 
Deve-se ressaltar que a MP em questão foi elaborada durante a gestão do então Ministro do Meio Ambiente Sarney Filho, que viria a coordenar a Frente Parlamentar Ambientalista e pertencer à Comissão Especial em 2009. A elaboração da medida foi coordenada pelo Conselho Nacional do Meio Ambiente (Conama), que contou com a participação de vários órgãos governamentais e de representantes do setor produtivo e das entidades ambientalistas. Nesse momento, o debate do Código Florestal adquiriu forças, evidenciando ainda mais os conflitos entre os adeptos do ambientalismo e do ruralismo. O relator da MP, deputado Moacir Micheletto (PMDB/PR), que viria a ser presidente da Comissão Especial de 2009, apresentou um projeto de lei de conversão (PLV) que tinha como parâmetro principal o instrumento técnico do Zoneamento Ecológico Econômico e gerou intensas polêmicas para o processo. Entretanto, por força da EC 32 de 2001, esse PLV não chegou a ser apreciado. As alterações provenientes da MP foram, então, consideradas como grandes avanços pelos ambientalistas.

Além da MP, a matéria foi também objeto de decretos presidenciais. Em julho de 2008, o Governo Lula, municiado pelo Ministério do Meio Ambiente, regulamentou as infrações e sanções administrativas relacionadas ao meio ambiente, estabelecendo o processo administrativo federal para apuração destas infrações, por meio do já mencionado Decreto 6.514. Conforme esse instrumento:

“Art. 152-A. Os embargos impostos em decorrência da ocupação irregular de áreas de reserva legal não averbadas e cuja vegetação nativa tenha sido suprimida até 21 de dezembro de 2007, serão suspensos até 11 de dezembro de 2009, mediante o protocolo pelo interessado de pedido de regularização da reserva legal junto ao órgão ambiental competente".

Por mais que já houvesse a Lei de Crimes Ambientais desde 1998, a regulamentação estipulando multas e infrações só se deu com esse decreto. Então, na prática, antes disso nenhuma multa havia sido aplicada. Foi com essa "pressão" que os parlamentares representantes do segmento ruralista se mobilizaram, conforme desenvolvido adiante, de forma suficiente para conseguirem deliberar sobre a reforma florestal, conseguindo a instalação da Comissão Especial em setembro de 2009, ou seja, três meses antes do prazo estipulado pelo decreto para a regularização das propriedades. 
No entanto, esse prazo foi continuamente prorrogado tanto pelo Governo Lula ${ }^{38}$ como pelo Governo Dilma ${ }^{39}$. Essas medidas de prorrogação do início da vigência das sanções administrativas podem demonstrar alguns elementos inerentes ao conflito polarizado. Enquanto o Ministério do Meio Ambiente referendou o Decreto 6.514 de 2008, os Ministérios do Desenvolvimento Agrário e da Agricultura, Pecuária e Abastecimento, juntamente com o primeiro, participaram da elaboração do Decreto 7.029 de 2009, que buscou formas de apoio mais flexíveis para a regularização ambiental dos imóveis rurais. Dessa forma, a existência de divergências também era perceptível ao nível da burocracia do Executivo.

Quanto à tramitação das proposições legislativas de iniciativa do Congresso, as discussões não foram muito diferentes. Estas foram dominadas por um cenário de polarização e divergências, o que impediu a maioria dos projetos sobre a matéria de tramitarem facilmente. A reforma promovida pela Comissão Especial teve sua origem com o Projeto de Lei (PL) 1.876 de 1999 de autoria do ex-deputado Sérgio Carvalho (PSDB/RO), que trazia apensadas 11 propostas semelhantes, revogando o Código Florestal vigente. Antes de ser instalada a Comissão, tais proposições estavam com a tramitação engessada nas comissões. De 1999 até 2006, a matéria ficou sob a análise da Comissão de Agricultura da Casa, relatada pelo deputado Moacir Micheletto (PMDB/PR). Conforme o relatório de Aldo Rebelo (2010, p. 39):

\begin{abstract}
"Analisado pela Comissão de Agricultura, Pecuária, Abastecimento e Desenvolvimento Rural, o projeto de lei foi rejeitado. Entendeu-se que o PL $1.876 / 1999$, não obstante ter o mérito de tentar corrigir alguns problemas da legislação em vigor, não equaciona esses problemas. Posteriormente foi rejeitado também pela Comissão de Meio Ambiente e Desenvolvimento Sustentável, sendo remetido ao arquivo em 31 de janeiro de 2007 por força do artigo 105 do Regimento Interno da Câmara dos Deputados. Foi desarquivado em 12 de julho do mesmo ano, após requerimento do Dep. Enio Bacci, momento a partir do qual passou a receber como apensos os demais projetos de lei."
\end{abstract}

\footnotetext{
${ }^{38}$ O Decreto 7.029 de 2009 instituiu o Programa Federal de Apoio à Regularização Ambiental de Imóveis Rurais, denominado "Programa Mais Ambiente" e prorrogou o início da vigência das punições do Decreto 6.514 de 2008 para 11 de junho de 2011. Foi referendado pelos Ministérios do Meio Ambiente, do Desenvolvimento Agrário e da Agricultura, Pecuária e Abastecimento. Ressalte-se que o Decreto foi publicado em 10 de dezembro de 2009, um dia antes do prazo estipulado.

39 O Decreto 7.497 de 2011 prorrogou o início da vigência das punições para 11 de dezembro de 2011, e foi referendado pelo Ministério do Meio Ambiente.
} 
Quadro 1. Cronologia de tramitação do PL 1.876/99 e eventos relacionados

\begin{tabular}{|c|c|c|}
\hline Local & Data & Fato \\
\hline \multicolumn{3}{|l|}{ MMA } \\
\hline & jan/1999 & Início da gestão Sarney Filho \\
\hline \multicolumn{3}{|c|}{ Câmara } \\
\hline & $19 / 10 / 1999$ & Apresentação do PL 1.876 de 1999 \\
\hline & $17 / 11 / 1999$ & Apreciação CAPADR (relator: Moacir Micheletto PMDB/PR) \\
\hline \multicolumn{3}{|c|}{ Governo } \\
\hline & $24 / 08 / 2001$ & Medida Provisória 2.166-67 \\
\hline & $11 / 09 / 2001$ & Emenda Constitucional 32 de 2001 \\
\hline \multicolumn{3}{|c|}{ MMA } \\
\hline & $\operatorname{mar} / 2002$ & Início da gestão José Carlos Carvalho \\
\hline \multicolumn{3}{|c|}{ Governo } \\
\hline & out $/ 2002$ & Eleição de Lula à Presidência \\
\hline \multicolumn{3}{|c|}{ Mudança de Legislatura } \\
\hline \multicolumn{3}{|c|}{ MMA } \\
\hline & $\mathrm{jan} / 2003$ & Início da gestão Marina Silva \\
\hline \multicolumn{3}{|c|}{ Câmara } \\
\hline & 05/01/2006 & Apreciação CMADS (relator: Luciano Zica PT/SP) \\
\hline & $20 / 04 / 2006$ & Apreciação CCJR (relator: Luciano Pizzato DEM/PR) \\
\hline \multicolumn{3}{|l|}{ MMA } \\
\hline & $\mathrm{mai} / 2008$ & Início da gestão Carlos Minc \\
\hline \multicolumn{3}{|c|}{ Governo } \\
\hline & $22 / 07 / 2008$ & Decreto 6.514 \\
\hline \multicolumn{3}{|c|}{ Mudança de Legislatura } \\
\hline \multicolumn{3}{|c|}{ Câmara } \\
\hline & 04/08/2009 & Apensação do PL 5.367/09 - Frente da Agropecuária \\
\hline & 08/09/2009 & Apreciação na CE (relator: Aldo Rebelo PCdoB/SP) \\
\hline \multicolumn{3}{|c|}{ Governo } \\
\hline & $10 / 12 / 2009$ & Decreto 7.029 \\
\hline \multicolumn{3}{|l|}{ MMA } \\
\hline & $\mathrm{abr} / 2010$ & Início da gestão Izabella Teixeira \\
\hline \multicolumn{3}{|c|}{ Câmara } \\
\hline & 06/07/2010 & Aprovação do substitutivo na $\mathrm{CE}$ \\
\hline \multicolumn{3}{|c|}{ Governo } \\
\hline & out $/ 2010$ & Eleição de Dilma à Presidência \\
\hline \multicolumn{3}{|c|}{ Mudança de Legislatura } \\
\hline & $03 / 05 / 2011$ & Aprovação de urgência para a apreciação no Plenário \\
\hline & $11 / 05 / 2011$ & Discussão e apresentação de emendas \\
\hline & $24 / 05 / 2011$ & $\begin{array}{l}\text { Aprovação do substitutivo e da emenda } 164 \text { (Autor: Paulo Piau } \\
\text { PMDB/MG) }\end{array}$ \\
\hline
\end{tabular}

Governo

09/06/2011 Decreto 7.497 
Senado

02/06/2011 Apreciação CCJ (Relator: Luiz Henrique PMDB/SC)

22/09/2011 Apreciação CCT (Relator: Luiz Henrique PMDB/SC)

27/10/2011 Apreciação CRA (Relator: Luiz Henrique PMDB/SC)

11/11/2011 Apreciação CMA (Relator: Jorge Viana PT/AC)

01/12/2011 Discussão em Plenário

06/12/2011 Aprovação do substitutivo e apresentação de emendas no turno suplementar

Câmara

09/12/2011 Apreciação do substitutivo do Senado (Relator: Paulo Piau $\mathrm{PMDB} / \mathrm{MG})$

25/04/2012 Aprovação do substitutivo do deputado Paulo Piau (PMDB/MG)

Governo

25/05/2012 Sanção parcial, Vetos e Medida Provisória 571

17/10/2012 Sanção parcial do PLV 21 (Lei 12.727 - novo Código Florestal)

Ao longo de sua tramitação, portanto, o PL 1.876 foi rejeitado tanto pela Comissão de Agricultura quanto pela Comissão do Meio Ambiente. Entretanto, os motivos da rejeição foram contrários. Para a primeira Comissão, o PL possuía o mérito de tentar elidir alguns problemas da legislação vigente, mas não seria suficiente para equacionar o impasse do cumprimento das normas que concernem à preservação e ao manejo dos recursos florestais ${ }^{40}$. Para a segunda, o momento era considerado completamente inoportuno para o debate de um novo Código Florestal, em face às principais alterações e complementações necessárias já constarem da MP 2.166 de $2001^{41}$.

Percebe-se que até antes da instalação da Comissão Especial, as demandas ambientalistas estavam sendo mais atendidas do que as dos ruralistas. A supracitada MP, considerada uma vitória ambiental, não permitiu espaço para a proposta defendida pelos ruralistas. O PLV do relator Micheletto não chegou a ser apreciado. Sendo assim, por mais de dez anos a legislação em análise ficou disciplinada por uma MP construída majoritariamente pelo segmento ambientalista. No mesmo sentido, a situação dos produtores rurais com ocupações irregulares se agravou com a edição do Decreto 6.514

${ }^{40}$ Parecer apresentado em 11 de outubro de 2005, perante a Comissão de Agricultura, Pecuária, Abastecimento e Desenvolvimento Rural (CAPADR), pelo ex-deputado Moacir Micheletto (PMDB/PR), p. 4.

41 Parecer apresentado em 21 de março de 2006, perante a Comissão de Meio Ambiente e Desenvolvimento Sustentável (CMADS), pelo ex-deputado Luciano Zica (PT/SP), p. 8. 
no Governo Lula, o que aumentou cada vez mais os anseios da bancada ruralista pela reforma do Código Florestal.

Não obstante o conflito político, a existência de divergências sobre essa matéria também se encontra na área técnica. Um possível diagnóstico sobre a proteção ambiental do país e a disponibilidade de terras para a produção agrícola depara-se com um cenário de incertezas e especulações. Dessa forma, vários estudos científicos poderiam ser apresentados para evidenciar tais divergências. $O$ presente trabalho, entretanto, limitou-se a apresentar alguns exemplos de cada lado. Ambas as fontes dos dados abaixo descritos pertencem a um mesmo nível burocrático, no caso, Ministério da Agricultura e Ministério do Meio Ambiente, evidenciando, mais uma vez, as divergências internas do Poder Executivo.

Em 2008, um núcleo da unidade Monitoramento por Satélites da Empresa Brasileira de Pesquisa Agropecuária (Embrapa), vinculada ao Ministério da Agricultura, desenvolveu um sistema de gestão territorial com base em dados de satélites e informações cartográficas digitais. Tendo em vista o conhecimento da quantidade de terras disponíveis para a atividade agrícola no Brasil, a pesquisa estimou e mapeou as áreas destinadas à preservação ambiental e unidades indígenas estabelecidas pela legislação do país, caso essa fosse integralmente aplicada. A Tabela 1 aponta os resultados obtidos para cada bioma nacional. Conforme a pesquisa, subtraindo-se as áreas destinadas à preservação, restaria apenas 28,8\% do território do país disponível para ocupação agrícola e urbana (MIRANDA, 2008).

Tabela 1. Áreas Legalmente Disponíveis para a Atividade Agrícola

\begin{tabular}{ccccccc}
\hline BIOMA & Área & $\begin{array}{c}\text { UCE/UCF/T } \\
\mathbf{I} *\end{array}$ & $\begin{array}{c}\text { Reserva } \\
\text { Legal }\end{array}$ & $\begin{array}{c}\text { Área de } \\
\text { Reserva } \\
\text { Legal }\end{array}$ & $\begin{array}{c}\text { APP } \\
\text { Líquida** }\end{array}$ & $\begin{array}{c}\text { Área } \\
\text { Dispon } \\
\text { ível }\end{array}$ \\
\hline AMAZÔNIA & $\left(\mathbf{k m}^{2}\right)$ & $\left(\mathbf{k m}^{2}\right)$ & $\%$ & $\left(\mathbf{k m}^{2}\right)$ & $\mathbf{k m 2}$ & $\mathbf{k m 2}$ \\
& 4.195 .296 & 1.947 .972 & $80 \%$ & 1.798 .644 & 782.854 & $\begin{array}{c}334.17 \\
4\end{array}$ \\
& & $46,43 \%$ & & $42,87 \%$ & $18,66 \%$ & $7,97 \%$ \\
CAATINGA & 844.062 & 50.500 & $20 \%$ & 158.713 & 60.002 & 574.84 \\
& & $5,98 \%$ & & $18,80 \%$ & $7,11 \%$ & $68,10 \%$ \\
CERRADO (fora da & 1.275 .908 & 72.518 & $20 \%$ & 240.678 & 176.555 & 786.15 \\
AML***) & & $5,68 \%$ & & $18,86 \%$ & $13,84 \%$ & $61,60 \%$
\end{tabular}




\begin{tabular}{|c|c|c|c|c|c|c|}
\hline \multirow[t]{2}{*}{$\begin{array}{c}\text { CERRADO (dentro } \\
\text { da AML) }\end{array}$} & 755.390 & 140.353 & $35 \%$ & 215.263 & 77.666 & $\begin{array}{c}322.10 \\
8\end{array}$ \\
\hline & & $18,58 \%$ & & $28,50 \%$ & $10,28 \%$ & $42,60 \%$ \\
\hline \multirow[t]{2}{*}{$\begin{array}{c}\text { MATA } \\
\text { ATLÂNTICA }\end{array}$} & 1.118 .353 & 70.695 & $20 \%$ & 209.532 & 180.220 & $\begin{array}{c}657.90 \\
7\end{array}$ \\
\hline & & $6,32 \%$ & & $18,74 \%$ & $16,11 \%$ & $58,80 \%$ \\
\hline \multirow[t]{2}{*}{ PAMPA } & 176.131 & 6.209 & $20 \%$ & 33.984 & 21.606 & $\begin{array}{c}114.33 \\
1\end{array}$ \\
\hline & & $3,53 \%$ & & $19,29 \%$ & $12,27 \%$ & $64,90 \%$ \\
\hline \multirow[t]{2}{*}{$\begin{array}{c}\text { PANTANAL(dentro } \\
\text { da AML) }\end{array}$} & $60.787,06$ & 3.263 & $20 \%$ & 11.505 & 57.524 & 11.505 \\
\hline & & $5,37 \%$ & & $18,93 \%$ & $94,63 \%$ & $18,90 \%$ \\
\hline \multirow[t]{2}{*}{$\begin{array}{l}\text { PANTANAL(fora } \\
\text { da AML) }\end{array}$} & $88.950,15$ & 2.833 & $20 \%$ & 17.223 & 86.117 & 17.223 \\
\hline & & $3,18 \%$ & & $19,36 \%$ & $96,82 \%$ & $19,40 \%$ \\
\hline TOTAL & 8.514.877 & $\begin{array}{c}2.294 .343 \\
26.9 \%\end{array}$ & & $\begin{array}{c}2.685 .542 \\
31,5 \%\end{array}$ & $\begin{array}{c}1.442 .544 \\
17 \%\end{array}$ & $\begin{array}{c}2.455 .3 \\
50 \\
28,8 \%\end{array}$ \\
\hline
\end{tabular}

*UCE/UCF/TI refere-se à Unidade de Conservação Estadual, Unidade de Conservação Federal e

Territórios Indígenas.

**APP refere-se à Área de Preservação Permanente.

***AML refere-se à Amazônia Legal.

Fonte: Miranda (2008)

Os resultados da pesquisa se referem às áreas disponíveis caso a legislação brasileira fosse totalmente aplicada. Assim, não apontam a situação atual de proteção e disponibilidade, mas indicam que a legislação então vigente necessitaria de adaptações para que pudesse ser aplicada na prática. A publicação da pesquisa saltou aos olhos do grupo ruralista, que, como será visto adiante, utilizou-se de tais resultados para defender a necessidade de reforma do Código Florestal.

Em contrapartida, enquanto os dados da Embrapa apontavam que o território brasileiro estaria mais do que protegido pela legislação ambiental, alguns índices de desmatamento do país demonstravam que a realidade era diferente. Levantamento realizado pelo Ministério do Meio Ambiente (2007), com base em imagens de satélite de 2002, indicou o grau de devastação dos biomas nacionais (Tabela 2). Segundo a consultora legislativa da Câmara, Roseli Ganem (2010), esses dados são considerados conservadores por técnicos da área ambiental, uma vez que a realidade parece mais perversa. Entretanto, são as informações oficiais disponíveis.

Tabela 2. Cobertura original e área desmatada de cada bioma em 2002 


\begin{tabular}{|c|c|c|c|}
\hline Bioma & $\begin{array}{l}\text { Cobertura } \\
\text { relação } \\
\text { nacional) }\end{array}$ & $\begin{array}{l}\text { Original }(\% \text { em } \\
\text { ao território }\end{array}$ & 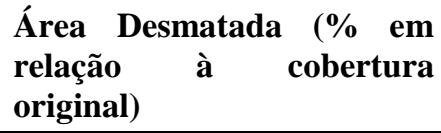 \\
\hline Amazônia & & 49,8 & 12,5 \\
\hline Cerrado & & 24,1 & 39,0 \\
\hline Mata Atlântica & & 12,5 & 73,0 \\
\hline Caatinga & & 9,7 & 36,6 \\
\hline Pantanal & & 1,9 & 11,5 \\
\hline Pampa & & 2,0 & 59,0 \\
\hline
\end{tabular}

Fonte: MMA (2007)

Dessa forma, ambos os lados do debate possuíam amparo técnico para respaldarem suas demandas. Esse cenário de incertezas e divergências foi utilizado para fomentar a polarização dos trabalhos da Comissão Especial. Nas palavras de duas consultoras legislativas da Câmara dos Deputados (ARAÚJO e JURAS, 2011, p. 3), ao analisarem o texto aprovado pela Casa em 2011:

"Entende-se que os problemas do texto aprovado pela Câmara dos Deputados ao PL $\mathrm{n}^{\circ} 1.876 / 1999$ e apensos deveria ter seu conteúdo em grande parte revisto. Cabe destacar que essa é a posição técnica pessoal das autoras que assinam esse estudo, não podendo ser tomada como representando a opinião da Consultoria Legislativa, até mesmo porque em um tema como esse sempre haverá divergências técnicas."

Indicadores, eventos e feedbacks sobre o Código Florestal sempre existiram. Os dados sobre o desmatamento da vegetação brasileira ganharam forças desde a década de 90, juntamente com o aumento das bandeiras ambientalistas. Tanto que a MP 2.166 de 2001, dentre outras preocupações ambientais, aumentou consideravelmente a área da reserva legal das propriedades rurais da Amazônia Legal. Após quase uma década sem alterações legislativas mais profundas, os resultados da pesquisa da Embrapa sobre a disponibilidade de terras para a atividade agropecuária demonstraram a necessidade de outra interpretação do problema existente. Contudo, tais dados não foram suficientes para que a questão ganhasse a devida atenção, mas foi um elemento necessário para a construção social do problema realizada pelos ruralistas.

\subsection{Fluxo das Soluções}

Após uma década de tramitação sem sucesso, a reforma do Código Florestal ganhou destaque na agenda legislativa com a apresentação do PL 5.367 de 2009, de 
autoria do deputado Valdir Colatto (PMDB/SC), então coordenador da Frente Parlamentar da Agropecuária, e 46 coautores. Esse projeto pretendia instituir o Código Ambiental Brasileiro e revogar o Código Florestal vigente. Foi apensado ao PL 1.876 de 1999 e, por sua abrangência, necessitou da criação de uma Comissão Especial. A instalação de Comissões Especiais na Câmara dos Deputados é prevista pelo Regimento Interno da $\mathrm{Casa}^{42}$ para tratar de proposições de emenda à Constituição, de projetos de código e de proposições que versem sobre matéria de competência de mais de três Comissões Permanentes. O projeto dos ruralistas foi distribuído entre oito comissões para análise de mérito. A apresentação desse projeto, com amplas ambições de mudanças na legislação, demonstrou o grau dos anseios e mobilizações da Frente da Agropecuária. Para fundamentar e justificar essa proposta, utilizou-se substancialmente a pesquisa publicada pela Embrapa (MIRANDA, 2008). A justificativa do PL 5.367 de 2009 (p. 44), que ensejou a criação da Comissão Especial, alega que:

\footnotetext{
“Os estudos realizados e apresentados por técnicos da Embrapa sobre o impacto nacional da legislação ambiental e indigenista demonstram que, se aplicada à legislação ambiental em sua íntegra, restariam aproximadamente $1 / 3$ do território nacional disponível para ocupação, estradas, cidades, produção de alimentos e outros, no entanto mais de 50\% do território já está ocupado. (...) Os avanços técnicos e científicos das últimas décadas nos permitem aprimorar a legislação para que ela tenha a verdadeira função protetiva com vistas a sustentabilidade."
}

Apoiada por essas informações, a Frente Parlamentar da Agropecuária, através de 47 representantes, antecipou-se ao prazo do Decreto 6.514 de 2008, que estaria por vencer em dezembro de 2009, e apresentou sua proposta de reforma da legislação. Em setembro do mesmo ano, mobilizou, juntamente com a Frente Parlamentar de Apoio ao Cooperativismo, representantes do setor produtivo e outros interessados para a realização do Seminário "Código Ambiental Brasileiro - Pacto Federativo Ambiental Descentralizado" na Câmara dos Deputados. O evento contou com a presença do então ministro da Agricultura, Pecuária e Abastecimento, Reinhold Stephanes (PMDB/PR) ${ }^{43}$, que viria ser membro da Comissão Especial após deixar a pasta, e do então Presidente da Câmara dos Deputados, ex-deputado Michel Temer (PMDB/SP). Nessa ocasião, Temer assinou o ato de criação de uma comissão especial para unificar em um projeto

\footnotetext{
${ }^{42}$ Regimento Interno da Câmara dos Deputados, Art. 34.

43 Enquanto ministro e membro da Comissão Especial, Stephanes pertencia ao PMDB. Filiou-se ao PSD em 2011.
} 
de lei todas as propostas de legislação florestal ou ambiental em tramitação na Casa. Definiu que a votação desse novo projeto pelo Plenário da Casa deveria ocorrer até o dia 11 de dezembro, quando terminaria o prazo previsto para todas as propriedades do País se adaptarem às normas vigentes sobre a averbação da reserva legal.

A criação da Comissão Especial simbolizou uma passagem fundamental da agenda governamental para a decisória. As alternativas existentes já eram várias, representadas nos diversos projetos em tramitação sobre o assunto. Ao oferecer um projeto que, por sua abrangência, obrigatoriamente ensejaria a criação de uma Comissão Especial, a Frente da Agropecuária fez com que a matéria passasse a ser objeto de decisões mais substanciais. Enquanto os ruralistas lutavam pela reforma, os ambientalistas buscavam evitar maiores mudanças na legislação. Nesse sentido, as lideranças de cada lado procuraram o apoio de comunidades geradoras de alternativas. Acadêmicos, pesquisadores, representantes de ongs e de produtores rurais, além dos consultores da Câmara e assessores governamentais eram chamados para debaterem suas ideias. Reuniões e audiências foram realizadas frequentemente a partir da criação da Comissão. Embasados nessas discussões, os parlamentares, assessores e representantes de cada setor trabalharam na difusão e defesa de suas propostas, como empreendedores da política.

A apresentação do PL 5.367 da Frente da Agropecuária demonstrou que esse grupo já estava mobilizado e unido para empreender sua proposta. Assim, por mais que houvesse diferenças entre os interesses do pequeno, médio e grande produtor, a unificação do discurso foi obtida, construindo a imagem de uma classe unida em torno da defesa dos seus interesses. Esse tipo de conduta é coerente com a abordagem do primeiro capítulo, que aponta o diferencial estratégico da bancada na sua capacidade de administrar vários níveis de decisão, facilitado pelo domínio do sistema da CNA.

Em contrapartida, a Frente Ambientalista não obteve a mesma facilidade de unificação. Conforme os consultores legislativos entrevistados, havia uma divisão entre os que queriam ou não ceder durante a negociação. A partir do modelo de Kingdon, essa frente pode ser caracterizada como uma comunidade mais fragmentada, o que dificulta a definição de uma alternativa. Dessa forma, o trabalho de seleção de sua proposta torna- 
se mais moroso, enquanto a bancada ruralista ganha tempo e espaço para difundir o seu projeto e trabalhar pela aceitação do mesmo.

\subsection{Fluxo Político}

Caracterizando a criação da Comissão Especial como a passagem da matéria florestal para a agenda decisória, pode-se dividir o fluxo político em dois períodos: (a) estabilidade governamental e manutenção da legislação existente (2003/2008); e, (b) instabilidade governamental e afrouxamento de sua atuação (2008/2009). O primeiro período foi marcado por uma continuidade no governo e na pasta ambiental. Já o segundo, por uma troca de ministros e pelas implicações pré-eleitorais.

De janeiro de 2003 a maio de 2008, o Ministério do Meio Ambiente (MMA) foi comandado pela ex-senadora Marina Silva. Nesse período, a pasta aumentou a participação social na elaboração de suas políticas, visto que muitos dirigentes das ongs assumiram cargos no MMA. A gestão de Marina Silva perpassou a reeleição do então presidente Lula, mantendo-se com certa estabilidade intra-burocrática. A legislação florestal foi preservada e a atuação governamental se dava no sentido de expandir a proteção ambiental. Entretanto, em 13 de maio de 2008, Marina afirmou que deixaria o cargo por conta das dificuldades que enfrentava no governo. Em carta ao presidente Lula: "Esta difícil decisão, Sr. Presidente, decorre das dificuldades que tenho enfrentado há algum tempo para dar prosseguimento à agenda ambiental federal"44

Foi empossado como ministro o então Secretário de Estado do Ambiente do Rio de Janeiro, deputado estadual Carlos Minc. Sua gestão foi repleta de ações polêmicas, como o caso do "Boi-Pirata" ${ }^{45}$ e a denominação de "vigaristas" ${ }^{46}$ para os parlamentares da bancada ruralista. Para a consultora legislativa entrevistada, o perfil midiático do ministro piorou o conflito entre ambientalistas e ruralistas, eliminando o respeito entre as partes. Especificamente quanto ao Código Florestal, conforme os assessores especiais do MMA entrevistados, nessa época havia uma postura de evitar que o debate sobre a matéria ganhasse forças no Congresso Nacional, pois sabiam que lá a correlação de

\footnotetext{
${ }^{44}$ Biografia disponível em seu portal eletrônico.

${ }^{45}$ Iniciativa de apreensão de gado em propriedades ilegais por agentes do Ibama apoiados por forças policiais. Minc anunciava que os animais apreendidos seriam destinados ao Programa Fome Zero.

${ }^{46} \mathrm{Na}$ marcha do Grito da Terra de 2008, em Brasília, o ministro teria chamado de "vigaristas" os parlamentares da bancada ruralista do Congresso Nacional.
} 
forças era desproporcional. Assim, a partir do Grito da Terra ${ }^{47}$ promovido em 2008 em Brasília, cujas reivindicações incluíram revisões no Código Florestal, o governo começou a construir uma posição comum entre suas pastas, para evitar que o Congresso iniciasse o debate. Entretanto, o Ministério da Agricultura, Pecuária e Abastecimento (MAPA) se retirou do acordo para permitir que o Legislativo resolvesse a questão. E, do outro lado, o então ministro Carlos Minc, preparando sua saída do MMA para candidatar-se a deputado estadual no Rio de Janeiro, abrandou sua atuação.

Além do conflito intra-burocrático, o ano de 2009 também foi marcado pelas implicações do período pré-eleitoral ${ }^{48}$. A aliança do PT com o PMDB concedeu poderes ao segundo partido. Assim, pela entrevista feita com os assessores do MMA, a Comissão Especial foi criada pelo Michel Temer como uma concessão do fortalecimento do PMDB. Até o futuro presidente da Câmara, deputado Marco Maia (PT/RS), entraria com esse compromisso.

Nessa situação, percebe-se que o fluxo político teve influência não apenas na passagem do Código Florestal para a agenda decisória, mas também na forma de organização dessa agenda. O processo de geração e seleção das alternativas começou com a difusão da proposta ruralista já na frente da dos ambientalistas. Conforme afirmado por Kingdon, a chance de um item passar para a decisão é bastante elevada quando seus empreendedores conseguem ligar o problema, a alternativa e a receptividade. A bancada ruralista teve a percepção de fazer essa junção e aproveitar o momento político de instabilidade governamental e de mudanças na pasta ambientalista.

\subsection{A virada Ruralista}

As principais ideias do modelo de multiple streams foram respaldadas pela compreensão da formação da agenda do Código Florestal, visto que a existência de cada tipo de fluxo não era suficiente para a reforma ter acesso à agenda decisória. A frente ruralista foi capaz de unir esses fluxos em um momento propício para defender sua

\footnotetext{
${ }^{47}$ Conforme disposto no site da CONTAG: "O Grito da Terra Brasil é a principal ação de massa do Movimento Sindical de Trabalhadores e Trabalhadoras Rurais (MSTTR). É promovido pela CONTAG, Federações dos Trabalhadores na Agricultura (FETAGs) e pelos Sindicatos dos Trabalhadores e Trabalhadoras Rurais (STTRs). Reúne anualmente, na capital federal, milhares de pessoas de todo o país, entre lideranças, agricultores(as) familiares, assalariados(as) rurais, assentados(as) e acampados(as) da reforma agrária, dentre outros que apoiam as bandeiras de luta da população rural.".

${ }^{48}$ Em 2010 ocorreram eleições federais e estaduais.
} 
demanda. Conforme afirmado por Kingdon, as políticas não são construídas aos pares com problemas e soluções. Diversos projetos de lei tramitavam há uma década no Congresso Nacional como soluções e alternativas à questão. Entretanto, a simples existência dessas soluções não era suficiente para tornar o problema como um elemento central na agenda. Assim, a interpretação do problema como uma construção social foi fundamental para a mudança.

Da mesma forma, o fluxo político propiciou um ambiente favorável à abertura da janela, percebido pela frente ruralista. Se para Kingdon os fluxos dos problemas e da política são mais influentes na agenda governamental, enquanto que o fluxo das alternativas, na agenda decisória, no caso do Código Florestal, tem-se que o fluxo político é igualmente relevante em ambas as agendas. A instabilidade governamental propiciou não só o momento ideal para a apresentação do projeto ruralista, mas também que o processo de defesa das alternativas já começasse conforme os anseios e necessidades dessa bancada.

Como visto nos próximos capítulos, a supremacia ruralista na Comissão Especial criada utilizou-se da prerrogativa das audiências públicas e reuniões externas para difundir suas propostas, mobilizando atores internos e externos ao processo e ganhando legitimidade com o relator. $\mathrm{O}$ empreendedorismo de tal frente possibilitou a predominância de suas demandas e alternativas no processo de elaboração da nova legislação. 


\section{A Lógica da Ação}

A análise da tramitação legislativa do Código Florestal levará em consideração a natureza da reforma e as regras do processo decisório em que ela se deu. Considerar a natureza da reforma implica verificar se as propostas eram politicamente viáveis ou não, ou seja, se seus custos e benefícios eram dispersos ou concentrados. De forma complementar, as regras do processo são fundamentais para se entender a atuação dos defensores e opositores da proposta e as supostas vitórias e derrotas de cada um. Ao analisarem a reforma da previdência (1995/1998) com esses mesmos focos, Figueiredo e Limongi (1998, p. 67) apontaram que:

"(...) a luta entre os defensores e opositores de uma determinada medida
passa a englobar a disputa pelo próprio processo por meio do qual a decisão
será tomada. (...) Nestes termos, boa parte da disputa política entre grupos
pró e contra uma determinada medida se traduz em uma disputa em torno das
regras e procedimentos que regularão o processo decisório. Conflitos sobre
regras e procedimentos decisórios são conflitos sobre políticas públicas e
sobre quem as determina."

Para explorar os efeitos da organização do processo decisório no Legislativo, os autores recorreram à teoria de Douglas Arnold (1990). De forma semelhante, este trabalho se baseará no mesmo arcabouço teórico. Para isso, uma breve contextualização dessa teoria faz-se necessária. Sinteticamente, a literatura norte-americana sobre estudos legislativos - elaborada a partir da abordagem neo-institucionalista - divide-se em três modelos teóricos: distributivista, informacional e partidário. Conforme Limongi (1994, p. 37), esses modelos - oferecidos por seus autores em oposição uns aos outros divergem tanto no campo teórico quanto no campo empírico. São, assim, visões excludentes.

O modelo distributivista parte da premissa de que os políticos têm como principal objetivo a reeleição (Mayhew, 1974). Eles escolhem as políticas públicas que favoreçam as suas chances de se reeleger. Nesse modelo o voto do eleitor também é formado por cálculos sobre quem lhes oferece benefícios tangíveis e dispersa os custos. Dessa forma, a relação entre os congressistas é essencialmente conflituosa, visto que cada um deles deseja levar mais benefícios para seu eleitorado. A cooperação entre os parlamentares torna-se necessária para que as políticas sejam aprovadas, o que pede a troca de votos e apoios entre eles. No interior da visão distributivista, instituições 
específicas, o sistema de comissões, conferem estabilidade a esse processo de troca. (Limongi, 1994, p. 13).

Contrapondo-se à perspectiva distributivista, o modelo informacional tem como referência central o trabalho de Krehbiel (1991). Ele define dois postulados para a organização legislativa: o majoritário - dependência dos projetos legislativos da aprovação da maioria - e o da incerteza - na relação entre políticas e resultados, as consequências não são completamente previsíveis ou perfeitamente antecipadas. A informação incompleta seria a característica distintiva da teoria informacional. Nessa linha, o problema se coloca de duas formas (p. 67): (i) fornecer incentivos para que haja especialização, tendo em vista os recursos escassos e os custos para os membros se especializarem; e, (ii) fornecer incentivos para os especialistas compartilharem seus conhecimentos. O arranjo institucional, dessa forma, influencia os benefícios da aquisição da expertise e se essa será compartilhada com os outros.

Enquanto os modelos distributivista e informacional consideram apenas as vontades individuais, a perspectiva partidária alerta para a importância dos partidos como estruturadores da atividade legislativa (Limongi, 1994, p. 6). O ponto de vista partidário considera as instituições como expressão e meio de controle dos partidos sobre o processo legislativo. Cox e McCubbins (1993) promoveram uma reinterpretação sobre a fraqueza dos partidos norte-americanos, mostrando que a fonte de poder dos partidos está na capacidade de controlar a agenda decisória, ou seja, de definir o momento e o assunto que será objeto de decisão.

O presente trabalho optou por basear-se na perspectiva distributivista. Sendo o sistema de comissões o eixo estruturador das atividades legislativas do Congresso, as teorias divergem fundamentalmente quanto aos interesses que as comissões atendem. Para os distributivistas, são atendidos os interesses eleitorais individuais dos parlamentares. No modelo informacional, o interesse do plenário e sua necessidade de estimular a especialização. E, no partidário, o interesse eleitoral do partido. No estudo sobre a composição e os trabalhos da Comissão Especial do Código Florestal na Câmara dos Deputados a alegação distributivista sobre os interesses individuais é a mais convincente e que melhor se casa aos fatos. 
É com esse enfoque que a teoria sobre a tomada de decisões legislativas de Arnold (1990) foi formulada. Ela assume que os congressistas se preocupam intensivamente com a reeleição como uma meta dominante, mas não como a única meta. Isso significa que outras metas não serão desenvolvidas caso prejudiquem a principal, enquanto que, se a reeleição não é um risco, os parlamentares podem trabalhar por outros objetivos. A decisão parlamentar, portanto, é influenciada pela percepção dos eleitores quanto aos custos e benefícios de uma política e como essa percepção se tornará recompensa eleitoral. Para a compreensão da lógica dessa ação, Arnold define três grupos de atores - cidadãos ${ }^{49}$, legisladores e líderes - que tomam decisões de forma separada.

Esta seção se destina ao desenvolvimento dos principais elementos dessa teoria e a algumas considerações iniciais de sua aplicação à reforma do Código Florestal. Enquanto Figueiredo e Limongi consideraram a reforma da previdência como uma política inviável, visto que seus custos atingiam diretamente grupos específicos e seus benefícios eram dispersos e incertos, a reforma do Código Florestal será considerada como uma política rentável. Na medida em que os benefícios da flexibilização das regras de preservação ambiental nas propriedades rurais são claros e concentrados, seus custos são incertos e dispersos. É uma política não apenas viável, mas genuinamente rentável para os legisladores procurarem manter ou expandir seu apoio político.

\subsection{Natureza da política e percepção dos cidadãos}

Quando o legislador toma uma decisão, conforme Arnold, primeiro ele se pergunta qual alternativa contribui mais para suas chances de reeleição ${ }^{50}$. Se ele vê uma diferença significativa, escolhe a alternativa que mais o beneficia. Se não vê diferença, ele adota qualquer outro critério que achar relevante. Sua teoria é adequada para os

\footnotetext{
${ }^{49}$ Arnold diferencia os cidadãos em dois tipos: (i) público atento - cidadãos que conhecem questões específicas da agenda legislativa, sabem as alternativas em consideração e possuem relativas preferências sobre o que o Congresso deve fazer, como os grupos de interesse; e, (ii) desatento ou desmobilizado aqueles que não possuem nem preferências políticas firmes sobre uma questão nem sobre o que o Congresso está considerando.

${ }^{50}$ Conforme Figueiredo e Limongi (p. 66, nota 5) "A premissa estrita da reeleição pode ser substituída, no caso brasileiro, pela premissa da sobrevivência política, tendo em vista a comunicação constante, em termos de carreira, entre postos legislativos e executivos, nacionais e estaduais."
} 
casos em que as diferenças eleitorais importam. Assim, o principal problema é descobrir como os legisladores estimam as consequências eleitorais das suas decisões políticas. Além disso, as lideranças possuem o duplo trabalho de desenhar propostas e estratégias já antecipando os cálculos eleitorais dos eleitores. Ambos os atores precisam, portanto, de um modelo de como os cidadãos incorporam as posições políticas nas suas escolhas eleitorais.

Legisladores escolhem suas propostas estimando as preferências políticas potenciais dos cidadãos e a probabilidade dos cidadãos as incorporarem nas escolhas de eleições subsequentes. As preferências dos cidadãos dependem da incidência de custos e benefícios tanto quanto suas crenças sobre causa e efeito. A incidência de custos e benefícios se refere a quem ganharia e quem pagaria com a política, quanto e quando ganhariam ou perderiam. Com qual intensidade os legisladores devem se preocupar sobre os efeitos das políticas que produzem? David Mayhew (1974) alega que congressistas não necessitam se preocupar muito sobre efeitos políticos, visto que, em uma grande classe de decisões legislativas, a compensação eleitoral é mais para posições do que para efeitos. Entretanto, para Arnold, a probabilidade do voto retrospectivo depende diretamente da natureza dos efeitos e se eles podem ser conectados a uma única ação governamental, e não a muitas ações desconexas.

O debate sobre causa e efeito se dá de duas formas: (1) avaliação prospectiva envolve estimar quais consequências surgiriam se o governo adotasse um programa específico; (2) avaliação retrospectiva - inverte a direção da análise, a meta é encontrar as causas de problemas conhecidos. A avaliação prospectiva é feita sempre que o Congresso considera um novo programa. É esperado que os propositores mostrem como a escolha da política produzirá os efeitos pretendidos, e como eles podem ser realizados com um custo razoável, sem muitos efeitos indesejáveis. Opositores atacam em várias frentes. Eles podem tentar mostrar que a política não pode produzir os efeitos desejáveis, argumentando que a probabilidade de sucesso é muito baixa, ou defendendo outro programa que prometa alcançar os mesmos resultados a partir de outro caminho.

Já o voto retrospectivo possui outras consequências. Uma delas é a criação de uma classe de políticas inviáveis politicamente, em que os custos atingem grupos específicos e os benefícios são difusos - como a citada reforma da previdência 
(Figueiredo e Limongi, 1998). Uma segunda é a instigação de algumas políticas alternativas que poderiam alcançar os mesmos fins com menos riscos políticos. Finalmente, o voto retrospectivo também cria uma classe de políticas que são politicamente atrativas aos legisladores. Além de serem viáveis, também são rentáveis aos legisladores que, por meio delas, podem manter ou aumentar seus apoios políticos. Elas diferem das políticas inviáveis por distribuir benefícios perceptíveis dos quais os legisladores podem reivindicar o crédito.

Quando os efeitos da política atingem uniformemente os membros da sociedade, são benefícios ou custos genéricos, como crescimento econômico, melhora da saúde pública, inflação e combate a epidemias. Quando não atingem a sociedade uniformemente, são benefícios ou custos que atingem segmentos específicos. Muitos desses são grupos econômicos, como de ocupações específicas, indústrias, profissões ou classes econômicas. Também podem incluir segmentos não econômicos, como os demográficos de raça, idade, etnia. Entre eles estão os custos e benefícios geográficos, que se referem a efeitos que atingem as áreas geográficas de forma desproporcional, como regiões, estados ou localidades. Efeitos geográficos e de grupos específicos não são necessariamente excludentes. Muitas políticas possuem efeitos concorrentes em ambos os segmentos. Quando os efeitos estão concentrados tanto no grupo quanto na área geográfica, é praticamente certo que alguma mobilização de cidadãos emergirá.

Diante disso, a natureza da política é um dos fatores determinantes na forma de atuação dos defensores e opositores da política. No caso de uma proposta inviável, seus opositores buscarão formas de tornar clara a relação entre seus defensores e os custos gerados, como os casos de votação nominal e votações em separado, em que os legisladores devem se posicionar abertamente sobre os pontos da política (Figueiredo e Limongi, 1998). Em contrapartida, numa política rentável, cujos benefícios são tangíveis, seus propositores buscam aumentar a visibilidade do processo decisório e ainda reivindicar crédito pela aprovação. Contudo, o que mais pesa na decisão do parlamentar, segundo Arnold, é saber se os eleitores serão capazes de identificar sua contribuição para a proposta. Nesse sentido, o papel das lideranças será fundamental para aumentar ou diminuir o vínculo entre os custos da política e a contribuição de cada 
parlamentar. O uso de recursos institucionais, que podem alterar o processo das decisões, torna-se fundamental na determinação dos resultados.

\subsection{Lideranças e estratégias}

Ao definirem as políticas e os procedimentos, como as lideranças antecipam as necessidades eleitorais dos legisladores? Esta parte se destina ao exame das estratégias possíveis para construir coalizões elencadas por Arnold. Cada estratégia pertence a um plano de atrair suporte, tanto no Congresso quanto fora dele, pensando-se nos cidadãos atentos e nos até então desmobilizados.

Construir uma coalizão vencedora é um difícil trabalho como salienta Arnold. Nada acontece no Congresso a não ser que alguém planeje e trabalhe por isso. Alguém precisa definir os problemas, moldar as alternativas, iniciar a ação, mobilizar suporte, negociar compromissos e trabalhar para que o Congresso aprove o projeto. Aqueles que desempenham essas funções são denominados por Arnold como líderes de coalizões. Os líderes podem estar ou não no Congresso. Eles incluem líderes de comissões, líderes partidários, funcionários da Casa, autoridades do Poder Executivo, burocratas e líderes de grupos de interesse.

A quantidade de líderes não é uniforme pelos problemas e soluções. Algumas propostas atraem líderes em massa, enquanto outras oferecem poucos incentivos aos líderes. Propostas com efeitos geográficos concentrados tendem a adquirir legisladores das áreas afetadas. Aquelas com efeitos sobre grupos específicos tendem a atrair burocratas, líderes de grupos de interesse e alguns legisladores. Entretanto, alguns indivíduos se tornam líderes simplesmente porque suas posições os demandam. Essas distinções são importantes porque as estratégias adotadas dependem, em parte, do interesse central individual na proposta.

Líderes adotam estratégias para atingirem suas propostas antecipando os cálculos eleitorais dos legisladores, o que requer ambas as estimativas sobre os cidadãos - preferências potenciais e probabilidade de incorporação. Não há estratégias universais, mas líderes podem adaptar estratégias gerais à suas propostas específicas. Eles podem escolher entre três abordagens estratégicas, sendo que cada uma antecipa as necessidades eleitorais dos parlamentares de uma forma diferente: de persuasão, 
procedimento e modificação (Arnold, 1990, p. 92). Essas abordagens não exaustam todas as estratégias possíveis, mas totalizam as que dependem diretamente da conexão eleitoral.

A estratégia de persuasão envolve criar, intensificar ou mudar as preferências dos legisladores, públicos atentos e, se necessário, públicos desatentos. Em alguns casos, os líderes devem produzir grandes campanhas para ajustar as opiniões tanto da elite quanto dos cidadãos. Outra alternativa é restringir seus esforços no Congresso, focando em legisladores e nos públicos atentos, enquanto eles difundem a proposta nos vários estágios do processo legislativo. Não importa o estágio em que a construção da coalizão esteja, líderes sempre buscam persuadir os legisladores de que a proposta além de ser uma boa ideia, não gerará problemas eleitorais para eles. Essa meta pode ser alcançada gerando opiniões favoráveis nos públicos atentos e desatentos ou mostrando aos legisladores que é improvável o programa gerar opinião contrária caso os cidadãos tenham conhecimento dela. Em seus argumentos, os propositores tendem a aumentar os benefícios e minimizar os custos da medida. Os oponentes tendem a fazer exatamente o contrário

As estratégias procedimentais abrangem tentativas de influenciar os cálculos políticos dos legisladores pelo uso hábil das regras e procedimentos legislativos. Líderes podem construir barreiras procedimentais para proteger a legislação de mudanças. Frequentemente, a principal batalha é sobre quais regras irão prevalecer: as dos propositores ou dos opositores. Estratégias procedimentais são usadas para manipular as circunstâncias nas quais legisladores são forçados a tomar posições públicas. Podem adotar estratégias que fortaleçam ou diminuam a rastreabilidade da cadeia dos efeitos da política. Um método de mascarar a contribuição individual do legislador é delegar responsabilidade de tomar decisões desagradáveis ao presidente, burocratas, juízes, comissões regulatórias, agentes estaduais ou locais. Eles deixam a esses a alocação dos custos de programas específicos. O processo de delegação os isola da reação políticoeleitoral.

Finalmente, as estratégias de modificação envolvem a alteração de vários componentes da política, variando a incidência de custos e benefícios. A preocupação é moldar a política na melhor forma que acomode as preferências e potenciais 
preferências dos legisladores e dos cidadãos. Os líderes podem aceitar apenas um número limitado de mudanças para ainda terem um projeto que sirva a seus próprios interesses centrais. Eles possuem todos os incentivos para escolher as modificações cuidadosamente para que consigam aumentar o suporte da coalizão da política sem sacrificar a coalizão inicial. Uma das abordagens mais produtivas é modificar a proposta de forma que atraia líderes adicionais, que possam então persuadir outros para juntar à causa.

O que determina se os legisladores esconderão ou deixarão visível a dinâmica da elaboração da política para os cidadãos? Líderes podem propor delegar uma difícil questão ao executivo, mas legisladores podem facilmente rejeitar a proposta e insistir que o Congresso faça a política. Líderes podem inserir programas potencialmente controversos no meio de um grande projeto, mas oponentes podem demandar um voto separado no programa (Arnold, 1990, p.121). Isso demonstra que os legisladores não são apenas vítimas do trabalho das lideranças, mas também coautores. Os líderes definem as propostas, mas sem a aprovação dos parlamentares, não as concretizam. Em síntese, as decisões do Congresso dependem em parte do que cidadãos permitirão, do que os líderes propõem, das estratégias adotadas pela coalizão e oposição, e do que os legisladores preferem.

\subsection{Código Florestal: uma política rentável?}

Como afirma o próprio Arnold (1990, p. 7), sua teoria da tomada de decisões legislativas é adequada para os casos em que políticas alternativas afetam os retornos eleitorais dos políticos envolvidos. Isso significa que entre as propostas em debates, algumas contribuem mais ou menos para as chances de reeleição parlamentar. $\mathrm{Na}$ perspectiva distributivista, em que a meta dominante do legislador é sua reeleição ou sobrevivência política, a alternativa escolhida será a que mais o beneficia.

Para calcular seus benefícios e fazer suas escolhas, os legisladores devem estimar as preferências dos cidadãos e como elas afetarão seus desempenhos eleitorais. Assim, a visibilidade do processo de decisão pode contribuir ou não para as chances de reeleição. Caberá inicialmente às lideranças a percepção sobre as alternativas e 
procedimentos mais adequados para a maximização dos ganhos dos parlamentares que formarão as coalizões.

Ao se pensar nas propostas de reforma do Código Florestal, as diferenças eleitorais entre elas são evidentes, o que torna a teoria de Arnold ideal para a análise do caso. Ao tomar sua decisão, o parlamentar teve que se guiar pelos cálculos das possíveis recompensas eleitorais que cada alternativa lhe traria. A natureza dessa reforma poderia ser enquadrada nas duas principais classes de políticas propostas por Arnold: tanto como uma medida inviável quanto como uma política atrativa.

Se a alteração dessa matéria se desse no sentido de melhorar as garantias e condições da preservação ambiental, aumentando os índices de reservas legais e áreas de preservação, os produtores rurais arcariam diretamente com os custos de se adaptarem às regras e de terem uma lucratividade menor. Além disso, os estados que mais dependessem da produção rural seriam mais afetados do que os outros. Nessa hipótese, os custos atingiriam diretamente grupos específicos (segmento rural) e grupos demográficos (estados produtores), ou seja, é o caso de efeitos concorrentes que aumenta ainda mais a chance de mobilização dos cidadãos. Enquanto que os benefícios seriam avanços para a preservação ambiental do país, ou seja, seriam dispersos e uniformemente recebidos pela sociedade. Com essa perspectiva, a reforma seria uma medida politicamente inviável.

Em contrapartida, a defesa da flexibilização das medidas de preservação ambiental geraria benefícios concentrados aos grupos e estados específicos. Já os custos ocasionados pelas alterações seriam incertos e difusos. Visto que a falta de consenso técnico gerou especulação e divergência sobre os efeitos das mudanças no código florestal, o trabalho de persuasão dos opositores seria mais difícil. Nesse sentido, a reforma seria uma política não só atrativa, mas rentável aos legisladores que representam o setor rural. Seria uma oportunidade de manter e até expandir seus apoios políticos, reivindicando crédito eleitoral.

Se, conforme o teor dessa reforma, ela poderia se enquadrar em classes opostas de políticas, o resultado dela foi substancialmente determinado pela atuação das lideranças envolvidas. A antecipação dos trabalhos da bancada ruralista determinou a natureza da política e os procedimentos que moldariam o processo de decisão. Por outro 
lado, coube à bancada ambientalista, enquanto coalizão de oposição, buscar formas de demonstrar os custos da política, através da mobilização de outros segmentos sociais.

A descrição da bancada ruralista no primeiro capítulo deste trabalho demonstra que a construção de uma coalizão nesse setor não seria algo penoso. Tanto no Congresso quanto fora dele, os indivíduos ligados ao tema buscam unificação do comando, para se fortalecerem nas instituições do Estado. Isso porque apesar das divergências entre seus vários atores, em momentos de crise, todos se unem e se fortalecem enquanto classe. Além da expressividade por si só, a bancada ruralista também é caracterizada por uma alta capacidade de mobilização (Vigna, 2007), ou seja, potencial para mobilizar um número de parlamentares bem maior que os diretamente envolvidos com a bancada.

Para facilitar a ampliação da coalizão, as lideranças ruralistas buscaram definir um projeto que atendesse às necessidades eleitorais de seus representantes, tornando a proposta uma política rentável. Além de definir a natureza da política, essa liderança também soube escolher o procedimento que seria mais viável para a coalizão. No caso, aumentou o escopo da reforma, para que, regimentalmente, a matéria fosse obrigada a ser analisada por uma comissão especial.

O desenvolvimento do próximo capítulo busca explorar como as estratégias de persuasão, de procedimento e de modificação foram utilizadas pelos defensores e opositores da proposta. Nessa parte, a classificação da reforma como uma política atrativa torna-se ainda mais evidente, visto que não houve tentativa de delegação de questões ao Executivo e o fato de haver votação em separado no plenário da Câmara sobre um dos pontos mais polêmicos da matéria não constrangeu os parlamentares. Pelo contrário, a aprovação da emenda 164 - a emenda ruralista - foi comemorada como uma grande vitória por essa bancada. A coalizão buscou maior visibilidade para o processo. 


\section{A reforma do Código Florestal}

A aplicação do modelo de multiple streams à etapa de mudança na agenda ressaltou a atuação empreendedora das lideranças ruralistas. Elas souberam aproveitar o momento político de instabilidade intragovernamental para pautarem o problema da legislação florestal na agenda decisória do Congresso e do Executivo. Apresentaram, nesse contexto, uma proposta que defendia os interesses do setor agrário. Para que essa proposta fosse bem sucedida, seria necessária a continuidade da atuação da bancada. Em contrapartida, os ambientalistas deveriam consolidar uma coalizão e trabalhar pela rejeição da reforma.

Para a análise exploratória da tramitação da reforma florestal, serão considerados os principais elementos da teoria de Arnold. O foco será dado na conduta das lideranças de ambas as coalizões. O termo "liderança" abrangerá os coordenadores das frentes parlamentares e os legisladores mais atuantes de cada área. Além das lideranças, as decisões também foram moldadas pelo restante das coalizões, visto que todas as ações realizadas passaram pelo crivo de cada parlamentar.

O recorte da tramitação será na fase inicial da Câmara dos Deputados, ou seja, desde a instalação da comissão especial até a aprovação da matéria no Plenário da Casa. Enquanto as audiências públicas e reuniões externas demonstram os interesses existentes na matéria, as votações no Plenário da Câmara apontam os resultados obtidos pelas coalizões. Além disso, as votações também evidenciam como as estratégias de modificação e de procedimentos influenciaram esses resultados. Como a questão central deste trabalho abrange a organização das coalizões e os recursos utilizados por elas, entende-se que esse período da tramitação foi decisivo na reforma florestal.

Este capítulo também se destina a concluir se as decisões parlamentares alcançaram o seu maior objetivo: a reeleição. Considerando o modelo de cálculo eleitoral de Arnold, a atuação das coalizões não seria bem sucedida se não houvesse recompensa eleitoral. No caso do Código Florestal, como as eleições federais ocorreram no auge do debate na Câmara, três meses após a aprovação do substitutivo na comissão especial, tem-se que os efeitos dessa reforma devem ter, pelo menos em alguma medida, influenciado as escolhas eleitorais. 


\subsection{Estratégias Procedimentais}

Conforme visto no capítulo 3, a discussão sobre o Código Florestal ocorria formalmente no Congresso desde 1999. Entretanto, o PL 1.876 de 1999 ficou estagnado nas comissões permanentes até 2009. Nesse período, os interesses ambientalistas vinham sendo contemplados, em alguma medida pelo menos, com o controle da discussão pelo Executivo, através dos decretos referendados pelo Ministério do Meio Ambiente e resoluções do Conama. Segundo os assessores do MMA entrevistados, era fato que o Executivo não desejava uma maior discussão da matéria no Congresso, com o receio de que qualquer mudança na legislação proveniente dessa Casa seria resultado de uma correlação de forças desproporcional entre ruralistas e ambientalistas.

Nessa situação, a bancada ruralista necessitava encontrar uma forma para deixar de ser um ator coadjuvante, passando a principal. Para garantir a existência de uma comissão, em que o controle seria mais fácil do que no plenário, caso a matéria fosse direto para ele, os membros da Frente Parlamentar da Agropecuária apresentaram o PL 5.367 de 2009, que, por sua abrangência de mérito, foi despachado a oito comissões permanentes. Como o Regimento Interno prevê a criação de Comissão Especial para tratar de proposições que versem sobre matéria de competência de mais de três comissões permanentes, nem seria necessário mobilização política para a instalação da comissão. Ela seria obrigatoriamente criada. As lideranças ruralistas se fundamentaram em uma regra regimental que seria adequada para influenciar o processo de tomada da decisão.

Entretanto, não seria apenas a criação de uma comissão o suficiente para a obtenção dos resultados desejados pelos ruralistas. A sua composição seria outro elemento determinante do processo. Dentre titulares e suplentes, a Comissão foi composta por 35 deputados indicados pelas lideranças partidárias, respeitando-se a proporcionalidade das representações das bancadas. Como este estudo tem sido pautado pela divisão entre os segmentos de ruralistas e ambientalistas, foi necessário classificar dessa forma as posições dos membros da Comissão. O gráfico 4 demonstra que a 
composição da comissão dividiu-se entre posicionamentos ruralistas (22), ambientalistas (7), representantes da agricultura familiar (4) e neutros $(2)^{51}$.

\section{Gráfico 4. Composição da Comissão Especial}

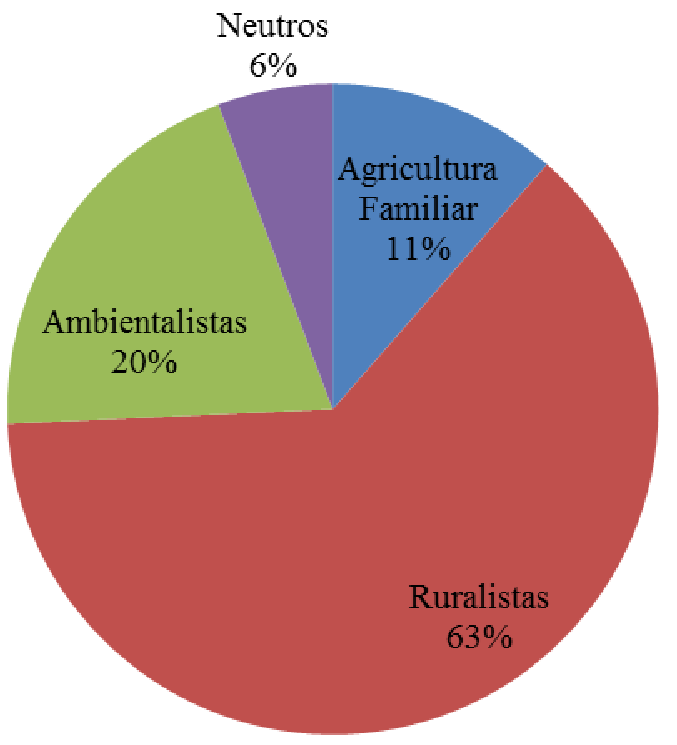

A hegemonia ruralista em contraponto à baixa representatividade dos ambientalistas seria um indicador da correlação de forças desproporcional que guiaria os trabalhos da Comissão. Para a obtenção dessa situação, as lideranças ruralistas tiveram que atuar junto às lideranças partidárias. É interessante notar que a maioria dos partidos não se preocupou em equilibrar o debate no momento das indicações dos membros da Comissão. Com exceção do PSOL, PV, PSB, PCdoB e PT, todos os outros partidos foram representados por parlamentares vinculados às demandas ruralistas. Salvo o PSDB que obteve um membro dentre suas quatro cadeiras ligado ao

\footnotetext{
${ }^{51}$ A classificação dos membros apresentada foi feita conforme: (i) financiamento da campanha eleitoral; (ii) o pertencimento ou não dos mesmos às Frentes Parlamentares da Agropecuária, da Agricultura Familiar e Ambientalista; (ii) atuação na Comissão de Agricultura e Pecuária e na Comissão de Meio Ambiente; (iii) análise dos dados biográficos retirados pelos sítios eletrônicos pessoais e pelo portal da Câmara dos Deputados. Em 2006, dentre os 23 deputados da Comissão que receberam financiamento eleitoral do setor agrícola, 17 são ruralistas, 4 ambientalistas, 1 da agricultura familiar e 1 neutro. Em 2010, dentre os 25 que receberam, 20 são ruralistas, 3 ambientalistas 1 da agricultura familiar e 1 neutro. Ressalte-se que, enquanto a média do financiamento do setor dos membros ruralistas aproxima-se de $40 \%$ da campanha, a dos ambientalistas e demais, de $2 \%$. Com esse parâmetro comparativo, não há como se falar que os não-ruralistas também são financiados pelo setor agropecuário..
} 
ambientalismo, os outros partidos preencheram $100 \%$ de suas vagas com os representantes do segmento ruralista. O gráfico 5 demonstra essa hegemonia:

Gráfico 5. Representação Partidária na Comissão

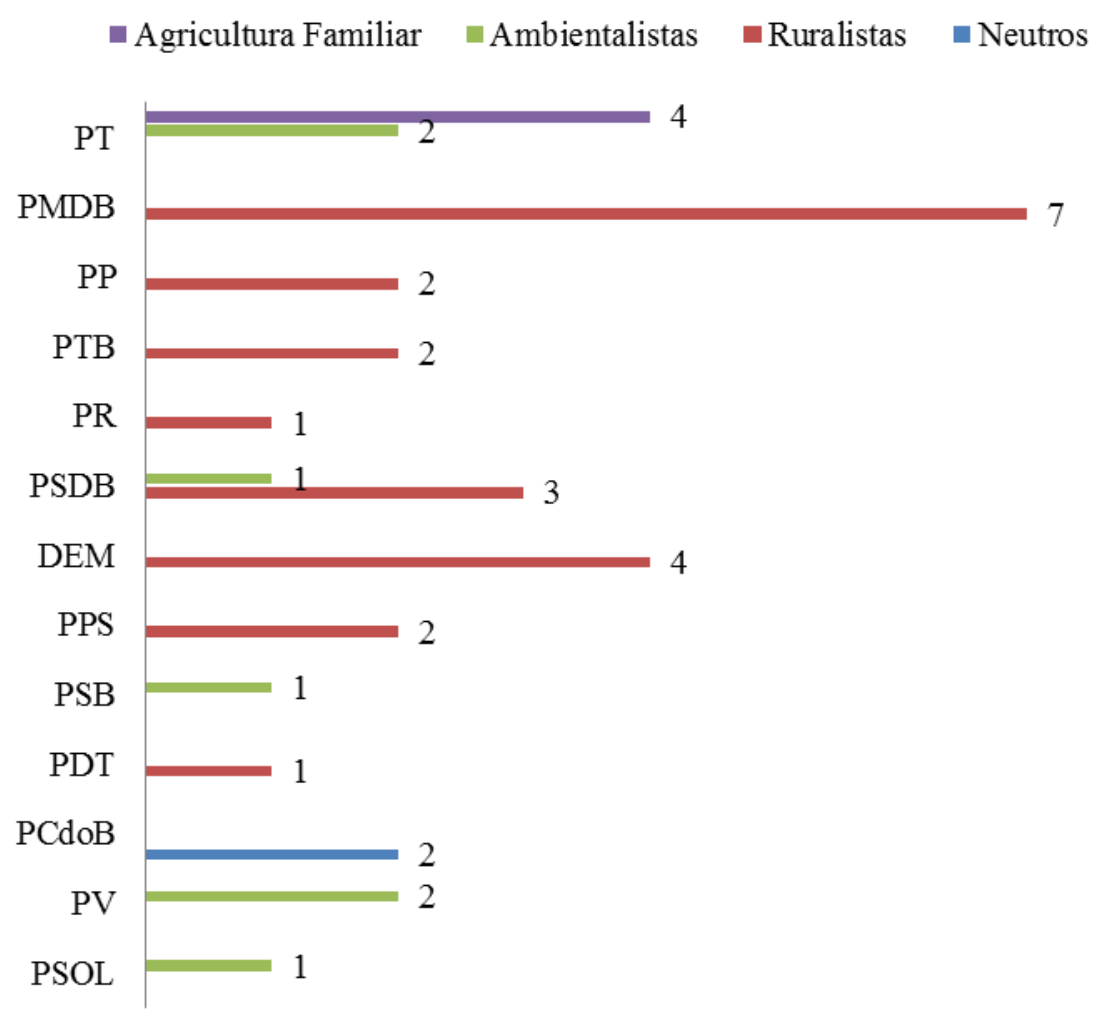

Até mesmo a bancada governista (PMDB/PT/PP/PR/PTB/PSC/PTC/PTdoB), que totalizou 18 vagas na Comissão, foi predominada por membros ligados ao setor ruralista. Todos possuíam relações com a temática da Comissão, defendendo as bandeiras de agricultura familiar (4) ou do ambientalismo (2). Entretanto, o restante da bancada (12) foi dominada por parlamentares representantes do outro setor. Com uma composição tão enviesada a favor dos interesses ligados à agricultura, os resultados dos seus trabalhos podiam ser antecipados com alto grau de certeza. Assim, o que esperar da coalizão de oposição? Durante as primeiras reuniões para a instalação da Comissão, questões de ordem sobre o assunto foram apresentadas. Conforme a ata da $2^{\mathrm{a}}$ reunião ordinária $^{52}$, realizada em 06 de outubro de 2009:

"O Deputado Ivan Valente solicitou que constasse em Ata que lhe foi negada a palavra, como líder, para comunicação de liderança. Em seguida,

\footnotetext{
${ }^{52}$ Disponível em: http://www.camara.gov.br/internet/ordemdodia/integras/699366.htm - acessado em 20 de junho de 2012
} 
apresentou questão de ordem, com base no art. $34, \S 1^{\circ}$, do Regimento, para que pelo menos metade dos membros titulares da Comissão fosse composta por membros titulares das Comissões Permanentes que deveriam ser chamadas a opinar sobre a proposição em causa. O Deputado Edson Duarte informou que havia formulado questão de ordem sob o mesmo fundamento no plenário da Câmara e propôs que os trabalhos fossem suspensos até que a questão fosse decidida pelo Presidente da Câmara. Contraditou a questão de ordem, o Deputado Valdir Colatto sob o argumento de que a prerrogativa de indicar os membros da Comissão era dos líderes, e o artigo mencionado servia de recomendação aos líderes, não cabendo questionamento a respeito."

Com essas questões de ordem, percebe-se que os ambientalistas também buscaram recursos institucionais para tentar alterar o processo. De fato, o Regimento Interno dispõe que pelo menos metade dos membros da Comissão Especial deve ser composta por membros titulares das Comissões Permanentes envolvidas com a matéria em análise. Como no caso o mérito do projeto era de competência de oito comissões, estava evidente que nem todos os temas estavam representados, visto que a Comissão da Agricultura e Pecuária estava em peso. Contudo, as questões de ordem foram indeferidas pela presidência da $\mathrm{Casa}^{53}$. Assim, a supremacia dos representantes ruralistas indicados pelas lideranças partidárias permaneceu durante os trabalhos da Comissão.

Com toda essa vantagem, seria muito improvável que a coalizão ruralista não buscasse dominar também a mesa da Comissão. Elegeram como presidente o deputado Moacir Micheletto (PMDB/PR) e, como primeiro-vice, o deputado Anselmo de Jesus (PT/RO). Esse parlamentar, representante do PT, era coordenador da Frente Parlamentar da Agricultura Familiar na época. O fato de haver um representante do PT na mesa colaborou para atenuar o viés da comissão. Entretanto, o parlamentar foi cuidadosamente escolhido, visto que, por mais que ele fosse ligado à agricultura familiar, sua atuação da Comissão de Agricultura e Pecuária já demonstrava a sua abertura às demandas dos outros segmentos rurais.

Ao presidir a Comissão, a bancada ruralista pôde se apropriar de outros recursos institucionais influentes nos resultados. Um deles foi a definição do relator. Conforme justificativa do presidente Micheletto, dentre uma composição tão polarizada, a escolha do relator buscou a definiçãa de uma personalidade neutra. Nomearam o então deputado Aldo Rebelo (PCdoB/SP), que, de fato, não pertencia formalmente a nenhuma das

\footnotetext{
${ }^{53}$ Os ofícios de indeferimento das questões de ordem não foram localizados.
} 
frentes envolvidas. No momento da designação do relator, o PCdoB era partido não apenas integrante da base aliada, como os vínculos entre ele o PT são historicamente conhecidos. Além disso, o deputado Aldo Rebelo já havia sido ministro do governo Lula e presidente da Câmara dos Deputados ${ }^{54}$, demonstrando alta aceitabilidade dentro do Executivo. Esse respaldo político do relator foi fortemente apropriado pela bancada ruralista visando aumentar a legitimidade de suas demandas. Definição estratégica ou não, conforme visto no próximo tópico, os ruralistas conseguiram influenciar a produção do relatório de Rebelo com o trabalho da persuasão.

Se flexibilizar a legislação florestal era uma medida rentável para a coalizão hegemônica, outra tática foi aumentar a visibilidade do processo e evitar qualquer possibilidade de delegação das decisões. Nesse aspecto, duas ações principais evidenciam a busca por tornar claro o vínculo de cada parlamentar com a reforma florestal: realização de audiências públicas e reuniões externas e votação em separado da emenda 164 no Plenário.

A previsão regimental da prática de audiências públicas permite aos parlamentares trazerem ao debate os convidados de seu interesse. Trazer um representante de seu eleitorado produz recompensas eleitorais na medida em que demonstra a atuação do legislador por aquela causa e ainda a sua preocupação com aquele segmento que está sendo ouvido. Além das dezenas de audiências públicas realizadas na Câmara dos $\operatorname{Deputados}^{55}$, a bancada ruralista na Comissão propôs a realização de reuniões externas, ou seja, audiências nos estados para ouvirem representantes locais. Essas reuniões foram coordenadas de forma informal pelos parlamentares. Alguns deles ficaram responsáveis por organizá-las em seus respectivos estados de representação. Os custos para a realização dessas reuniões não eram ressarcidos pela Câmara dos Deputados, e cada parlamentar deveria arcar com as despesas das viagens.

A maioria das reuniões ocorreu nos maiores colégios eleitorais dos membros que se propuseram a coordenar os eventos e que, obviamente, mobilizaram de forma

\footnotetext{
${ }^{54}$ Em 2004 e 2005, foi ministro de Relações Institucionais. E, de 2005 à 2007, presidiu a Câmara dos Deputados.

${ }^{55}$ A análise detalhada sobre as audiências públicas e reuniões externas será desenvolvida no tópico sobre o trabalho de persuasão.
} 
majoritária os tipos dos convidados para o debate. Se os organizadores dessas reuniões foram os próprios membros da Comissão que se dispuseram a isso, cada um em seu estado, era de se esperar que os parceiros políticos dos mesmos estivessem presentes. Assim, a participação dos produtores rurais foi predominante, através de várias formas de representação, como presidentes de associações, cooperativas, sindicatos e produtores individuais. Além disso, percebeu-se certo padrão dos participantes nessas reuniões. Quase em todas as reuniões externas estiveram presentes os secretários estaduais de meio ambiente e da agricultura, presidentes das federações da agricultura (entidades do sistema CNA) e presidentes das federações dos trabalhadores na agricultura. Já o setor ambiental foi minoritariamente representado, na proporção aproximada de um para cada quatro representantes dos produtores rurais.

Diante disso, questiona-se por que os membros ambientalistas também não organizaram esse tipo de reunião para definir as participações de forma mais expressiva. Uma percepção preliminar refere-se ao modo de enfrentamento do debate distinto entre as duas frentes parlamentares. Enquanto a frente da agropecuária ansiava por uma reforma, fazendo o possível para demonstrar ao relator as necessidades da produção agrícola do país, a frente ambientalista rejeitava as ideias de mudança, discordando da própria existência da Comissão com esse fim. Também foram contra a realização das reuniões externas, alegando que essas estavam sendo palco para os parlamentares se promoverem tendo em vista as eleições de 2010. Certos ou não, é importante constar que essas reuniões contavam com a presença de mil pessoas na média, e, em sua maioria, produtores rurais.

Além das audiências, outro recurso institucional utilizado foi a votação em separado no plenário da emenda 164 , conhecida como emenda ruralista, que tratou dos assuntos mais polêmicos da matéria ${ }^{56}$. Enquanto o texto-base aprovado com orientação favorável do governo suprimiu alguns dos pontos mais polêmicos do texto, mediante as condições de negociação ${ }^{57}$, a emenda 164 trouxe à votação um conteúdo que traria

\footnotetext{
${ }^{56}$ De autoria do deputado Paulo Piau (PMDB/MG) e coautores da bancada ruralista, a emenda previa a possibilidade de se estender aos estados o poder de decidir sobre atividades agropecuárias em áreas de preservação permanente (APPs) e regularizava a situação de ocupações ilegais em APPs.

${ }^{57}$ A negociação do texto-base será discutida no tópico sobre as estratégias de modificação.
} 
benefícios decisivos aos produtores rurais. Com essa distinção, ficaria mais fácil para os parlamentares da bancada reivindicarem o crédito eleitoral.

\subsection{O trabalho de persuasão}

Seguindo a teoria de Arnold, a estratégia de persuasão envolve criar, intensificar ou mudar as preferências dos atores envolvidos na decisão - líderes, parlamentares e cidadãos. Cabe às lideranças o trabalho de difundir os efeitos positivos da política. Nesse trabalho, os propositores tendem a aumentar os benefícios e minimizar os custos, enquanto a oposição deve fazer exatamente o contrário. Em relação ao Código Florestal, as preferências da coalizão ruralista já eram unificadas e intensas. Os maiores trabalhos da liderança ruralista seriam de persuadir o relator da matéria e atrair outras lideranças para ampliarem o apoio à reforma. Assim, o instrumento das audiências públicas e reuniões externas foram substanciais para o trabalho de difusão e aceitação da proposta ruralista. Conforme o relatório feito por Aldo Rebelo (2010, p. 239):

\footnotetext{
"As audiências públicas têm um relevante papel na configuração das leis. É neste momento que se estabelece o debate e aparecem todos os interesses envolvidos. É essa articulação que leva à formulação das leis. Durante as audiências públicas realizadas pela Comissão Especial muitos foram os problemas levantados ou reivindicações feitas."
}

Essa declaração demonstra que para o relator a realização das audiências públicas foi um dos principais meios para a aquisição de conhecimento dos problemas e dos interesses envolvidos no assunto. Dessa forma, este estudo buscou saber quais foram os atores chamados para participar dos debates. Durante os 11 meses de trabalhos da Comissão, foram apresentados 86 requerimentos solicitando audiências públicas e reuniões externas. Por mais que a representação ambientalista fosse expressivamente menor do que a ruralista, a quantidade de requerimentos apresentados por ambas chegou a ser quase equivalente ( 34 e 35 , respectivamente). Do restante, 13 foram de autoria do relator, 2 de autoria dos defensores da agricultura familiar e, 2 da representação 
entendida como neutra. O gráfico 6 classifica os convidados solicitados nos requerimentos conforme o segmento de representação ${ }^{58}$.

\section{Gráfico 6. Convidados solicitados nos Requerimentos de Audiências} Públicas

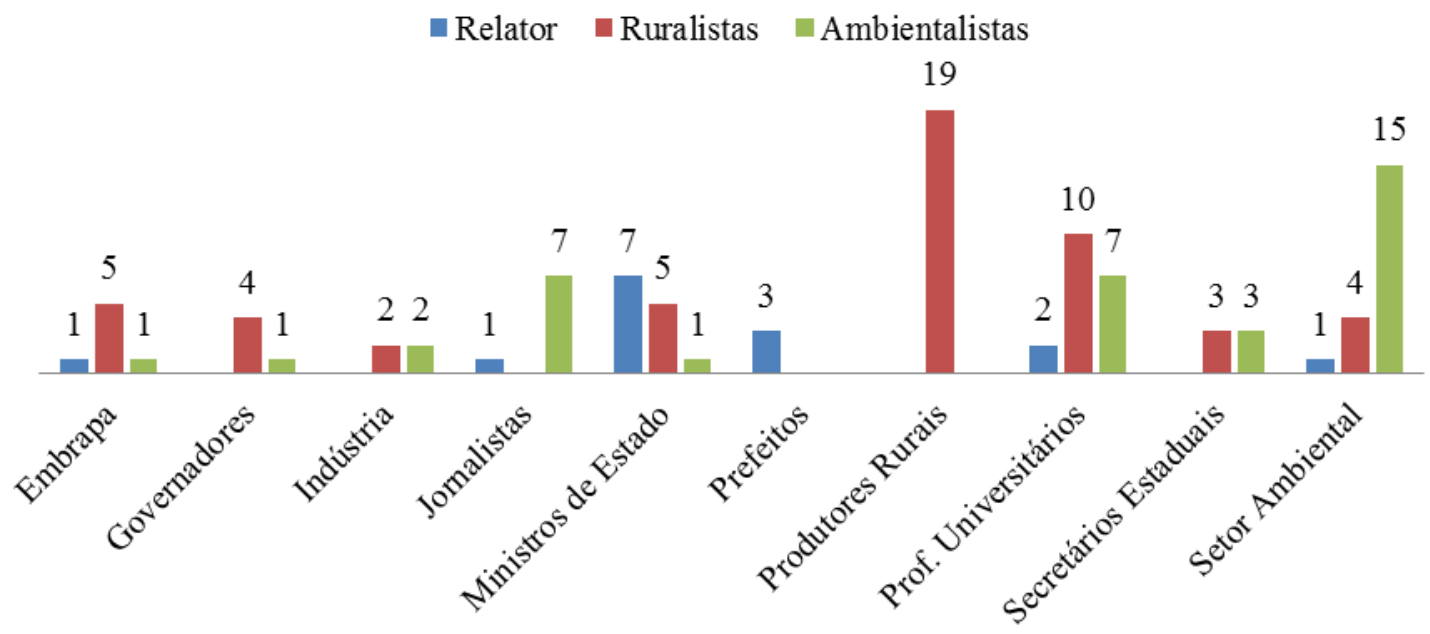

A maior busca de informação por parte do relator se deu no Poder Executivo, representado por seus Ministros de Estado, deixando os outros setores serem representados por convidados definidos pelos membros da Comissão. Essa "permissividade" pode ser justificada tanto pela falta de envolvimento inicial do relator com a matéria, quanto pela expressiva quantidade de requerimentos apresentados pelas bancadas da Comissão, o que demonstraria o cenário conflituoso que já estava armado para o debate. Nesse contexto, Rebelo pode ter optado por solicitar as informações oficiais do governo, através de seus Ministros, e por permitir que os interesses envolvidos se expressassem livremente. Tanto que, como era de se esperar, os interesses realmente foram solicitados conforme cada frente parlamentar. Os ruralistas buscaram o apoio das entidades representantes dos produtores rurais, e, os ambientalistas, das representantes do setor de proteção ambiental. Além disso, ambas as frentes também procuraram respaldo em outros setores de representação, como professores universitários e secretários estaduais. Entretanto, o perfil de cada ator era selecionado

58 Os convidados dos 86 requerimentos foram classificados conforme a entidade ou setor que representavam. Entretanto, apenas os setores com mais de 2 convites foram incluídos no gráfico. Dentre as classificações de "Indústria" e "Produtores Rurais" incluem-se associações, federações, sindicatos e cooperativas. "Setor Ambiental" abrange associações, institutos, ongs e movimentos sociais. 
conforme os anseios da frente. Enquanto os ruralistas chamaram secretários estaduais da agricultura, os ambientalistas, do meio ambiente. Da mesma forma ocorreram os convites para os professores universitários: os primeiros preferiam engenheiros agrônomos e os segundos, engenheiros florestais e biólogos.

O gráfico 6 também destaca o quanto os ruralistas buscaram a participação da Embrapa. Por ser uma empresa pública, caracterizada por avanços científicos e tecnológicos responsáveis pelo desenvolvimento da produtividade agropecuária do país, seu conhecimento possui grande relevância na matéria em questão. Conforme descrito no início deste trabalho, alguns dados por ela gerados foram intensamente apropriados pela bancada ruralista, visto que eles apontavam a necessidade de adequação da legislação ambiental. Assim, uma das "armas" dessa bancada foi o respaldo científico proveniente da Embrapa, demonstrando que, independentemente dos interesses envolvidos, o Código necessitava ser reformado.

Nesse ponto, pode-se afirmar que as audiências públicas foram instrumentos essenciais para o trabalho de aceitação das propostas das frentes parlamentares. Ainda mais por ser uma prerrogativa incentivada pelo relator da matéria, os membros da Comissão não poderiam abrir mão de solicitarem a participação de atores que, para eles, seriam capazes de defender as alternativas de seus segmentos. Nas palavras de Rebelo, em seu relatório (2010, p. 5):

\footnotetext{
"A Comissão Especial escolheu por método realizar audiências públicas em Brasília e nos Estados para colher as opiniões e os depoimentos de todos os interessados no debate sobre a matéria. Foram ouvidas as organizações não governamentais estrangeiras credenciadas no Brasil; as organizações não governamentais nacionais; as organizações não governamentais locais; os pesquisadores das universidades e da Empresa Brasileira de Pesquisa Agropecuária (Embrapa); as autoridades dos órgãos ambientais da União, de estados e municípios; governadores, prefeitos, vereadores; agricultores pequenos, médios e grandes, organizações representativas da agricultura, como a Confederação Nacional dos Trabalhadores da Agricultura (Contag), Confederação Nacional da Agricultura e Pecuária (CNA) e Organização das Cooperativas Brasileiras (OCB). Foi possível conhecer a diversidade e os desequilíbrios próprios do País que se revelam no debate do tema ambiental e florestal."
}

Se o método de aquisição do conhecimento foi a realização das audiências, era de se esperar que elas fossem imparciais. Entretanto, o levantamento de todos os seus participantes demonstra que a hegemonia ruralista da Comissão foi refletida nos debates promovidos. Considerando tanto as audiências realizadas em Brasília quanto as reuniões 
externas, totalizam-se 320 participações ${ }^{59}$. A especificação de todos os participantes encontra-se nos anexos. A classificação dos mesmos considerou a representatividade de cada indivíduo perante a matéria do Código Florestal $^{60}$. O gráfico 7 apenas não incluiu os setores que obtiveram menos de 2 participações e os participantes não identificados no relatório.

\section{Gráfico 7. Participações nas Audiências}

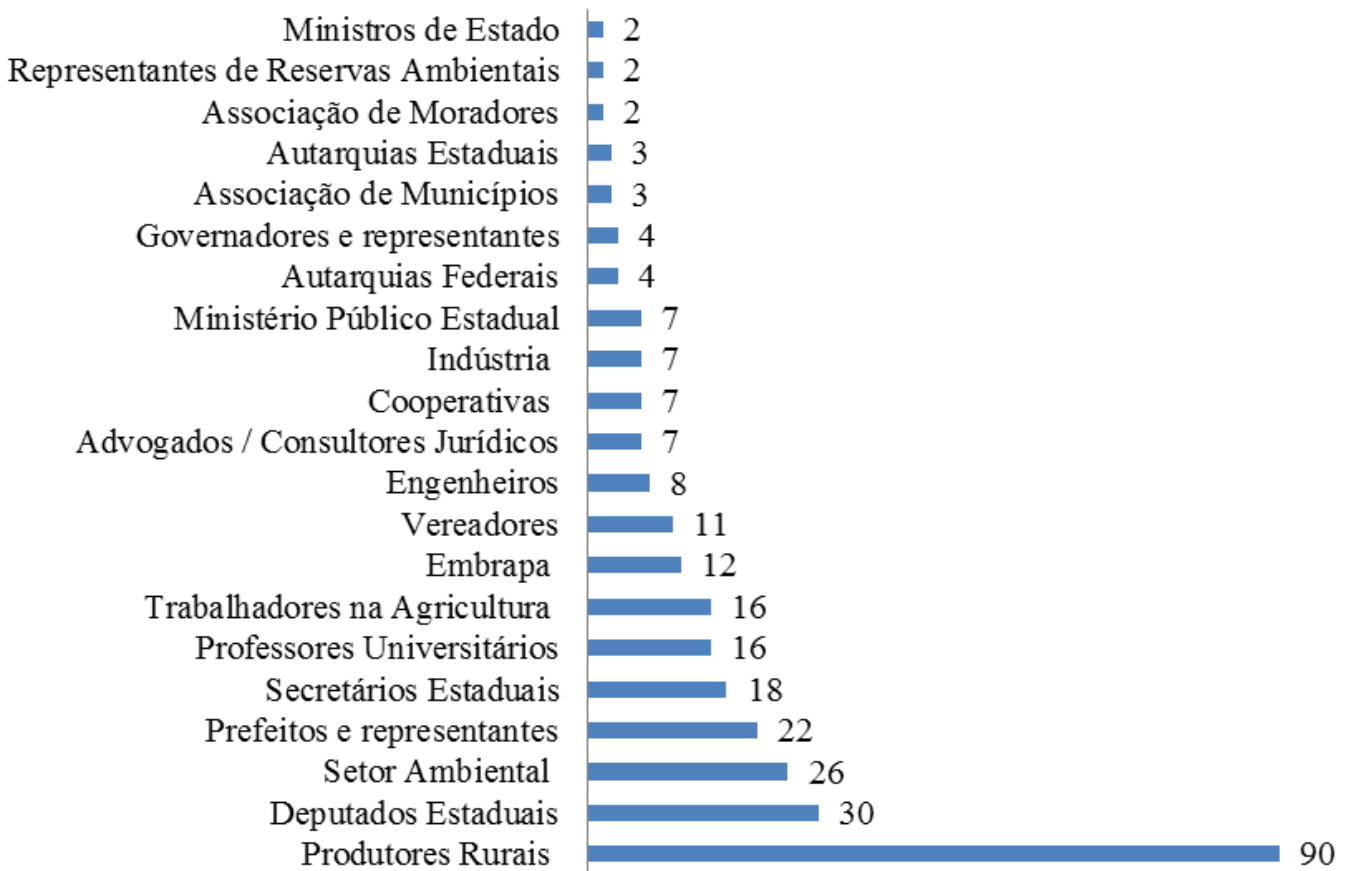

Para propiciar uma visão completa do trabalho da Comissão, esse gráfico apresenta os participantes das audiências de Brasília e das reuniões externas ao mesmo tempo. Entretanto, as proporções das representações dos setores foram bastante distintas entre elas. No que se refere às audiências realizadas na Câmara, na forma comum, os debates foram mais equilibrados entre os representantes dos produtores rurais e do setor

\footnotetext{
${ }^{59}$ Os dados sobre as audiências públicas e reuniões externas foram extraídos do relatório produzido por Aldo Rebelo. Com aproximadamente 200 páginas destinadas à descrição dessas reuniões, o relator especificou todos os participantes e os principais pontos dos discursos. Entretanto, duas reuniões ficaram sem registro dos participantes: a de Belém (PA) e a de Uberaba (MG).

${ }^{60} \mathrm{O}$ grupo "Produtores Rurais" abrange associações, federações, sindicatos e cooperativas do setor agropecuário; "Setor Ambiental", institutos, ongs, associações e fundações ligadas à defesa ambiental; "Trabalhadores na Agricultura", federações, conselhos e sindicatos; "Embrapa", chefes e pesquisadores; "Cooperativas", organizações; "Indústria", federações e sindicatos; "Engenheiros", agrônomos e florestais.
} 
ambiental. Elas também foram palco dos principais atores governamentais, como os Ministros do Meio Ambiente e da Agricultura e os representantes de autarquias federais. O quórum de presença dos parlamentares era razoável, sendo que sempre havia algum membro ambientalista no debate. Já as reuniões externas, conforme já exposto, foram predominadas pela mobilização ruralista, juntando centenas e, em algumas vezes, milhares de produtores e trabalhadores rurais. Nenhuma delas contou com a presença de algum membro ambientalista da Comissão.

A expressiva diferença entre a participação de representantes ruralistas e ambientalistas merece atenção. Sobre as audiências públicas, o Regimento Interno da Câmara dos Deputados dispõe que:

"Art. 256. Aprovada a reunião de audiência pública, a Comissão selecionará,
para serem ouvidas, as autoridades, as pessoas interessadas e os especialistas
ligados às entidades participantes, cabendo ao Presidente da Comissão
expedir os convites.
$\S 1^{\circ} \mathrm{Na}$ hipótese de haver defensores e opositores relativamente à matéria
objeto de exame, a Comissão procederá de forma que possibilite a audiência
das diversas correntes de opinião."

É interessante notar que todos os requerimentos apresentados foram aprovados. Se por um lado a bancada ambientalista ou a da agricultura familiar não era grande o bastante para rejeitar alguma proposição, os ruralistas eram e mesmo assim não o fizeram $^{61}$. O custo de se rejeitar as propostas seria maior do que simplesmente aproválas sem dar a devida relevância para que fossem efetivadas, visto estar a presidência da Comissão nas mãos de um representante ruralista. Segundo relato da secretária da Comissão Especial, servidora efetiva da Casa, era a mesa da Comissão que decidia quem seria convidado e quem não seria. Enquanto $68 \%$ dos requerimentos de autoria ruralista foram atendidos, apenas 29,4\% dos ambientalistas foram efetivados. Assim, nem tudo o que foi solicitado pelos requerimentos consolidou-se na prática.

Finalmente, quanto ao relator, seu papel de agente informacional foi utilizado de forma estratégica pela bancada ruralista. Rebelo apresentou outros tipos de argumentos para justificar a reforma defendida por essa frente, demonstrando que a proposta não existia devido aos interesses organizados apenas, mas também, por fatores de cunho

\footnotetext{
${ }^{61} \mathrm{O}$ quórum exigido para a aprovação das matérias na Comissão é de maioria simples e, em geral, a votação se dá por processo simbólico.
} 
econômico e social. Dedicado aos agricultores brasileiros, o parecer do deputado justificou as mudanças na legislação da seguinte forma (Rebelo 2010, p. 27):

\footnotetext{
"Diante do elevado grau de incerteza da maioria das hipóteses, adotar planos de contingência para todos os cenários imagináveis, mesmo os mais catastróficos e improváveis, baseados na hipótese de que 'o planeta se encontra à beira do colapso em decorrência da ação humana' e de que 'existem soluções de baixo custo', podem implicar em custos sociais e econômicos desproporcionais aos possíveis e mesmo improváveis ganhos, principalmente se consideramos a tendência de que a conta pesará mais sobre os pobres."
}

Com o trabalho da relatoria, Rebelo compreendeu que os custos seriam "desproporcionais aos possíveis e mesmo improváveis ganhos" de se adotar medidas para as hipóteses de que "o planeta se encontra à beira do colapso em decorrência da ação humana". Isso indica que, na visão do relator, não flexibilizar as regras de preservação ambiental geraria efeitos dispersos e incertos. Esse seria o caso de uma proposta politicamente inviável definida por Arnold. Nesse sentido, o substitutivo proposto por Rebelo contemplou pontos de mudanças defendidas pelo setor agrário, o que traria benefícios específicos e tangíveis, tornando a reforma uma política rentável à bancada ruralista. Foi uma vitória dessa bancada, portanto, o relatório gerado por Rebelo. Ela conseguiu não só persuadi-lo sobre a necessidade de mudança, quanto ganhar o apoio de outros setores através dos argumentos de cunho social trazidos pelo relator.

Em julho de 2010, a Comissão aprovou o substitutivo defendido pelos ruralistas e rejeitado pela minoria ambientalista. Do total dos membros presentes (18), foram 13 favoráveis - sendo 12 ruralistas e 1 representante da agricultura familiar, e 5 contrários - 3 ambientalistas e 2 da agricultura familiar. Dentre os membros do PT, o deputado Anselmo de Jesus, então vice-presidente da Comissão, votou conforme o relator. Os outros dois membros presentes votaram contra, apresentando votos em separado.

\section{3. $\quad$ Estratégias de modificação}

O processo decisório legislativo, conforme a teoria de Arnold, também é moldado pelas estratégias de modificação. Visando o melhor arranjo de preferências dos legisladores e cidadãos, os líderes podem aceitar alterações na proposta para adequar a incidência de custos e benefícios. Uma atitude a ser tomada é modificar a matéria de 
forma que traga apoio de outras lideranças, aumentando a coalizão. No cenário da reforma florestal, além da ruralista e ambientalista, havia outra coalizão decisiva: a governamental.

A conduta esperada pelos parlamentares era a de que o governo enviasse sua própria agenda sobre a matéria. Segundo a consultora legislativa da Câmara dos Deputados entrevistada, houve expectativa de que o Executivo enviaria o projeto durante todo o processo, com referências tanto a medidas provisórias quanto a projetos de lei. Pelo relato dos assessores especiais do MMA, o Executivo não chegou a produzir um texto, visto que a Casa Civil havia deliberado que um projeto do Executivo perderia para o substitutivo de Rebelo. Assim, houve uma ponderação de que o Executivo gostaria de tornar a proposta do Aldo o seu projeto. Além dessa possibilidade de perda para o parecer da Comissão, a divisão interna do Executivo também foi fator relevante para a ausência de um projeto próprio. O conflito de forças ocorreu entre o MMA e o MAPA e até internamente no PT - a decisão de apoiar o substitutivo de Rebelo venceu pela diferença de apenas um voto dentre os parlamentares do partido.

Sem uma proposta oficial do Executivo, o trabalho de negociação sobre a matéria tornou-se ainda mais relevante. Para obter o apoio do governo, o relator e a bancada ruralista necessitariam ceder em alguma medida. Após o primeiro documento emitido pelo MMA, posicionando-se sobre o substitutivo aprovado na Comissão, iniciaram-se os trabalhos de modificação do texto. Foi criada pelo então presidente da Câmara, deputado Marco Maia (PT/RS), uma Câmara de Negociação composta por partidos da base do governo, oposição e minorias, com o intuito de adequar a proposta de Aldo Rebelo conforme as demandas de cada partido e, principalmente, obter mais tempo para o governo definir sua proposta.

Aprovada em julho de 2010 na Comissão, a matéria conseguiu ser acordada para deliberação no Plenário apenas em maio de 2011. Nesse período ocorreram eleições e mudança de legislatura, o que pesou ainda mais para a modificação do texto de Rebelo. Segundo os assessores do MMA, ele cedeu ao governo até o último momento, de forma que o texto-base levado ao plenário já não era muito satisfatório para os ruralistas. A maioria dos pontos polêmicos havia sido eliminada, com o acordo de que seriam regulamentados por decreto. Foi nesse contexto que a matéria conseguiu ser 
expressivamente aprovada pela Câmara, com orientação favorável do governo para sua bancada. Dos 475 votantes, 410 foram favoráveis ao texto base. A tabela 3 demonstra que a disciplina partidária da quase totalidade dos partidos aproximou-se do índice expressivo de $100 \%$. Por mais que o líder do PT tivesse orientado a votação da bancada para aprovação, o partido governista se dividiu entre 45 favoráveis e 35 contrários, o que, perante o comportamento usual de unidade nas votações do partido, merece destaque.

Tabela 3. Votação do Texto-Base no Plenário da Câmara

\begin{tabular}{lcccc} 
Texto-Base & SIM & NÃO & Abstenção & Total \\
\hline DEM & 38 & 0 & 0 & 38 \\
PCdoB & 14 & 0 & 0 & 14 \\
PDT & 21 & 5 & 1 & 27 \\
PHS & 2 & 0 & 0 & 2 \\
PMDB & 74 & 0 & 0 & 74 \\
PMN & 4 & 0 & 0 & 4 \\
PP & 39 & 0 & 0 & 39 \\
PPS & 10 & 2 & 0 & 12 \\
PR & 31 & 2 & 0 & 33 \\
PRB & 11 & 0 & 0 & 11 \\
PRP & 1 & 0 & 0 & 1 \\
PRTB & 2 & 0 & 0 & 2 \\
PSB & 27 & 3 & 0 & 30 \\
PSC & 17 & 1 & 0 & 18 \\
PSDB & 47 & 1 & 1 & 49 \\
PSL & 2 & 0 & 0 & 2 \\
PSOL & 0 & 2 & 0 & 2 \\
PT & 45 & 35 & 0 & 80 \\
PTB & 21 & 0 & 0 & 21 \\
PTC & 1 & 0 & 0 & 1 \\
PTdoB & 3 & 0 & 0 & 3 \\
PV & 0 & 12 & 0 & 12 \\
Total & $\mathbf{4 1 0}$ & $\mathbf{6 3}$ & $\mathbf{2}$ & $\mathbf{4 7 5}$ \\
\hline
\end{tabular}

Entretanto, a bancada ruralista não estava satisfeita com o texto-base aprovado, visto que as concessões de Rebelo haviam retirado quase todos os benefícios almejados pelo grupo. A emenda 164, de autoria dos parlamentares ruralistas, conforme já dito, além de regularizar as propriedades irregulares no momento, previa a possibilidade de estender aos estados o poder de decidir sobre atividades agropecuárias em APPs. Esse 
ponto é considerado como um dos mais polêmicos da matéria, pois flexibiliza os limites das referidas áreas de preservação conforme decisão dos legisladores de cada estado. Segundo os assessores do MMA, com a emenda 164, nem Rebelo defendia mais o projeto. Assim, a emenda ruralista, como ficou conhecida, trouxe à votação um conteúdo mais polêmico. Na votação dessa emenda, alguns partidos liberaram as bancadas. E, dentre os de maior representação, a alta taxa de disciplina outra vez permaneceu, ficando o PT contrário aos dispositivos da emenda, de um lado, e o DEM, PMDB e PSDB favoráveis, do outro.

Tabela 4: Votação da Emenda Ruralista ${ }^{\mathrm{a}}$

\begin{tabular}{lcccc}
\hline Emenda 164 & SIM & NÃO & Abstenção & Total \\
\hline DEM & 35 & 1 & 1 & 37 \\
PCdoB & 12 & 1 & 0 & 13 \\
PDT & 9 & 17 & 1 & 27 \\
PMDB & 72 & 1 & 0 & 73 \\
PP & 23 & 11 & 0 & 34 \\
PPS & 9 & 2 & 0 & 11 \\
PR & 16 & 16 & 0 & 32 \\
PRB & 8 & 2 & 0 & 10 \\
PSB & 7 & 22 & 0 & 29 \\
PSC & 16 & 1 & 0 & 17 \\
PSDB & 45 & 3 & 1 & 49 \\
PT & 0 & 79 & 0 & 79 \\
PTB & 15 & 5 & 0 & 20 \\
PV & 0 & 12 & 0 & 12 \\
\hline a. Os partidos com menos de 10 representantes foram excluídos da \\
tabela.
\end{tabular}

Se por um lado o substitutivo de Rebelo foi profundamente modificado para se chegar ao texto-base apoiado pelo governo, por outro a bancada ruralista não abriu mão de seus interesses centrais ao defenderem a emenda 164. Votando em separado os pontos mais polêmicos através dela, que trazia benefícios claramente específicos aos segmentos rurais, eles aumentaram o vínculo de suas responsabilidades com a aprovação da política, ou seja, aumentaram a visibilidade do processo. Ao mesmo tempo em que, ao colocarem essa emenda em votação, estiveram sujeitos a não conseguirem aprová-la, o que seria uma derrota. Mas a coalizão que haviam construído foi suficiente para enfrentar a base governista e a oposição ambientalista. 


\subsection{Recompensas eleitorais}

Outro elemento importante para a análise da reforma florestal e que reforça ainda mais a teoria de Arnold é o fato de terem ocorrido eleições federais enquanto o debate estava em seu auge na Câmara dos Deputados. A Comissão Especial gerou seu substitutivo apenas três meses antes das eleições, no limite para o início das campanhas eleitorais. Essa proximidade era bastante citada pela bancada ambientalista, que não concordava em elaborar uma nova política com os debates acalorados pelas eleições. Já os ruralistas alegavam que essa reforma estava em discussão há mais de dez anos e os produtores rurais não poderiam mais esperar pelas mudanças.

A compreensão da ação dos parlamentares envolvidos, portanto, parte da premissa de Arnold que considera a reeleição a meta predominante desses atores. Para uma análise preliminar sobre os membros da Comissão Especial, nesse sentido, buscouse o levantamento de dois tipos de dados: (1) financiamento eleitoral - quem são os financiadores de cada bancada; e, (2) recompensas - o que mudou da eleição de 2006 para 2010. Dessa forma, além de simplesmente verificar se os parlamentares foram reeleitos ou não, buscou-se analisar se os meios para a reeleição, como o financiamento eleitoral, também foram beneficiados.

Para que a análise tivesse algum poder comparativo, foram levantados os dados das eleições de 2006 e de 2010. Dentre os 35 membros da Comissão, três deles não tentaram a reeleição. O financiamento eleitoral dos 32 membros, portanto, foi retirado da prestação de contas disponibilizada pelo Tribunal Superior Eleitoral (TSE). A análise levou em consideração o perfil das doações diretas recebidas pelos candidatos, excluindo-se do total da arrecadação os recursos provenientes de comitês e diretórios partidários. Como esse trabalho tem dividido os atores entre ambientalistas e ruralistas, buscou-se classificar os financiadores de uma forma que se aproximasse dessa polarização. Entretanto, não foi possível identificar financiadores relacionados ao setor ambiental, visto que, em sua maioria, as entidades representantes desse setor possuem o formato de institutos, associações e ongs ${ }^{62}$. Dentre os financiadores disponibilizados nas

\footnotetext{
62 A Lei 9.504 de 1997, que estabelece normas para as eleições, em seu art. 24. dispõe ser vedado o recebimento direto ou indireto de doação procedente de certas entidades, tais como, a de direito privado
} 
prestações de contas dos ambientalistas, encontram-se, na sua maioria, pessoas físicas. Assim, a análise dos financiadores conseguiu classificar apenas as entidades ligadas ao setor da produção agropecuária, que pode ser representado por outros tipos de pessoas jurídicas. Conforme a prestação de contas, classificou-se como "Setor Agropecuário" todas as pessoas jurídicas identificáveis como do ramo da agropecuária. Dentre elas encontram-se empresas e cooperativas do setor.

O levantamento sobre as doações financeiras do setor aos membros da comissão considerou qualquer quantidade recebida. Em 2006, dentre os 23 deputados que receberam financiamento eleitoral do setor agrícola, 17 são ruralistas, 4 ambientalistas, 1 da agricultura familiar e 1 neutro. Em 2010, dentre os 25 que receberam, 20 são ruralistas, 3 ambientalistas 1 da agricultura familiar e 1 neutro. Ressalte-se que, enquanto a média do financiamento do setor dos membros ruralistas aproxima-se de $40 \%$ da campanha, a dos ambientalistas e demais, de 2\%. Com esse parâmetro comparativo, não há como se falar que os não-ruralistas também são financiados pelo setor agropecuário. Em contrapartida, fica evidente a existência de grande parcela do financiamento proveniente desse setor para a bancada ruralista. Tanto que isso também foi objeto dos debates da Comissão. Na reunião deliberativa de 30 de março de 2010, foi apresentado o seguinte requerimento ${ }^{63}$ pelo deputado Ivan Valente (PSOL/SP):

\footnotetext{
"Requer a realização de audiência pública com representantes de empresas financiadoras de campanhas eleitorais para discutir e debater o Código Florestal, sugerindo o convite de representantes das seguintes empresas: Aracruz Celulose, Bunge Alimentos S.A., Klabin S.A., Companhia Siderúrgica Nacional, Caemi Mineração e Metalurgia S.A. e Votorantim Celulose e Papel."
}

Entretanto, essa proposição foi apresentada como contraponto a um requerimento apresentado pelo relator ${ }^{64}$ com o seguinte teor:

\footnotetext{
"Requer a realização de Audiência Pública com representantes do Banco Bradesco, Wolkswagen, Coca-cola, Colgate-Palmolive e American Express, financiadores da ONG SOS Mata Atlântica para discutir as propostas de alteração do Código Florestal."
}

que receba contribuição compulsória; entidade de utilidade pública; entidade de classe ou sindical; pessoa jurídica sem fins lucrativos que receba recursos do exterior; organizações não-governamentais que recebam recursos públicos; organizações da sociedade civil de interesse público. Dessa forma, as entidades do setor ambiental envolvidas na matéria do Código Florestal não podem possuir envolvimento com o financiamento das campanhas.

${ }^{63}$ Requerimento 83 de 2010, apresentado em 30/03/10.

${ }^{64}$ Requerimento 80 de 2010, apresentado em 30/03/10. 
Após provocarem grande tumulto na reunião, os parlamentares concordaram em retirar essas proposições ${ }^{65}$. Diante do exposto, percebe-se que ambos os lados possuíam preocupações quanto aos financiadores das campanhas, sendo a relação da bancada ruralista com essas entidades mais direta e visível.

É interessante destacar que as eleições de 2010 ocorreram logo após a aprovação do substitutivo pela Comissão, o que poderia demonstrar se os membros foram recompensados de alguma forma. Nessa eleição houve uma diminuição da proporção do financiamento eleitoral do setor agropecuário dos membros da Comissão, inclusive dos membros ruralistas. Para esses, $38 \%$ foi a média de financiamento do setor em 2006, e $31 \%$, em 2010. Entretanto, essa diminuição foi apenas na proporção do financiamento total, visto que os valores monetários aumentaram de 2006 para 2010 e, em alguns casos, de forma expressiva. Em 2006, o total de doações do setor aos membros ruralistas chegou a $\mathrm{R} \$ 4.047 .134,34$, E, em 2010 a $\mathrm{R} \$ 5.919 .817,29$, aumentando 46,3\%. O aumento do financiamento do setor agropecuário, contudo, ficou abaixo da média das doações empresariais feitas ao total de deputados eleitos, que cresceu $64,5 \%$ entre 2006 e $2010^{66}$.

Buscando saber como o financiamento do setor se dividiu entre os vários ramos da produção agropecuária, este trabalho realizou uma classificação das pessoas jurídicas selecionadas nas prestações de contas. Através da soma dos valores monetários das doações de cada setor identificável, foram elencados os principais tipos de produtores presentes nas doações. Ressalte-se que o ramo "Agropecuária" abrange pessoas jurídicas com a nominação genérica do termo, como, por exemplo, cooperativa agropecuária da região $\mathrm{X}$.

\footnotetext{
${ }^{65}$ Ata da $17^{\mathrm{a}}$ reunião ordinária realizada em 30 de março de 2010.

${ }^{66}$ TSE - Prestação de Contas disponível no portal eletrônico.
} 
Gráfico 8. Doações estimadas aos membros da Comissão (em Reais)

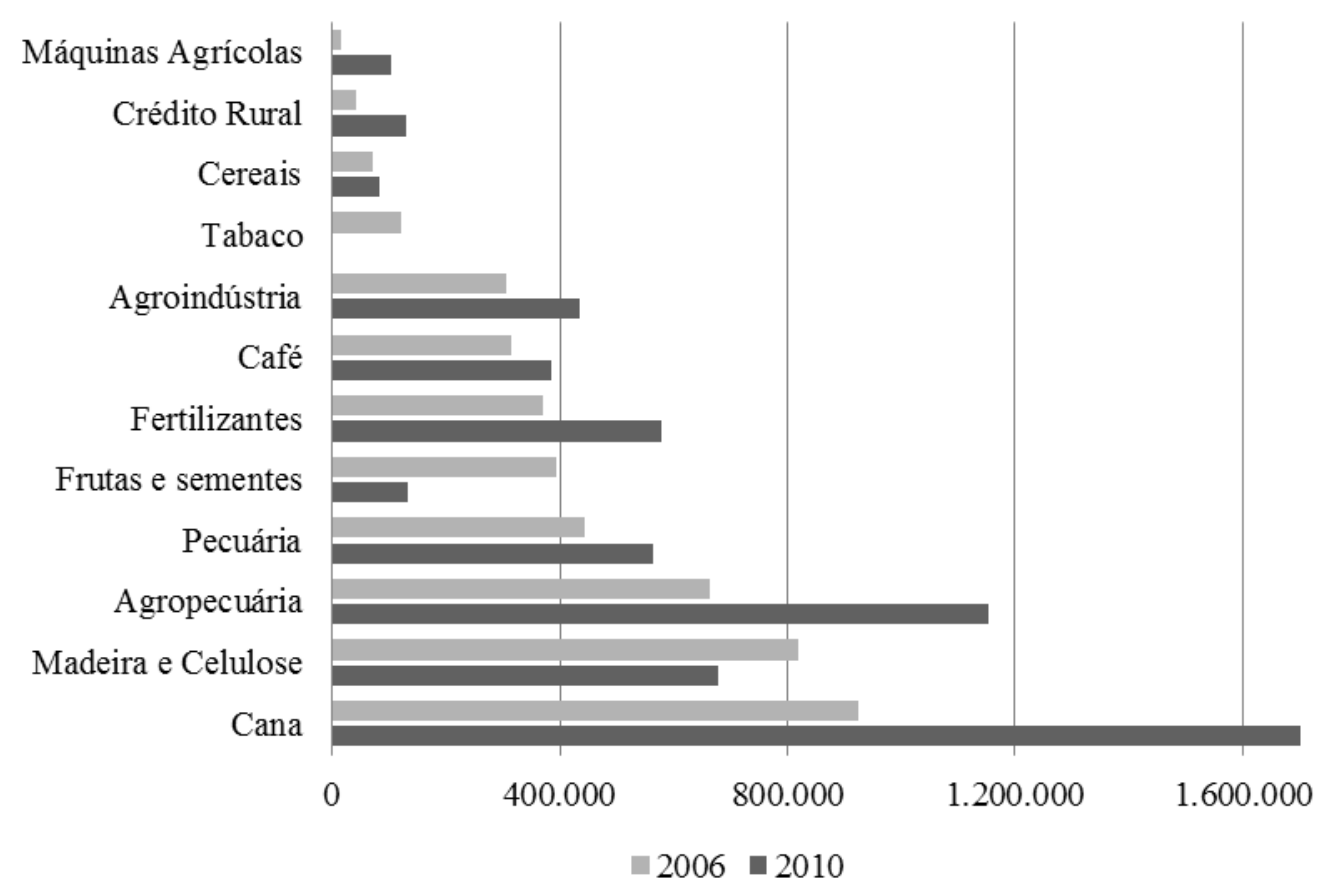

De 2006 para 2010, apenas o setor do tabaco deixou de doar para a bancada ruralista em análise. Além disso, com exceção dos ramos de frutas e sementes, e madeira e celulose, todos os outros setores produtivos aumentaram os valores de suas doações, tendo o ramo da cana-de-açúcar o aumento mais expressivo. Essas comparações podem demonstrar a existência de grandes recompensas eleitorais para os parlamentares. Após lutarem pela elaboração da reforma e defenderem uma proposta favorável a essas entidades, os legisladores não obtiveram apenas a continuidade dos financiamentos, mas, na maior parte das vezes, conseguiram aumentar a quantidade dos recursos recebidos para a reeleição.

Relacionando o modelo de cálculo eleitoral de Arnold, pode-se observar que, nesse caso, houve uma correlação das entidades financiadoras com o público atento. Dentre os 90 participantes das audiências públicas e reuniões externas, participaram associações, cooperativas, federações e produtores ligados a praticamente todos os setores classificados como doadores. Assim, a bancada ruralista foi capaz de estimar as recompensas provenientes da defesa dos interesses dos grupos envolvidos. Conforme Arnold, explicar por que interesses concentrados são geralmente vencedores é algo 
fácil. Pessoas que dividem um particular interesse são usualmente atentas ao que está acontecendo, e geralmente são organizadas em grupos. Possuem informações consideráveis sobre o que os legisladores estão fazendo por suas necessidades e possuem fortes incentivos para punir os legisladores por suas ações (Arnold, 1990, p. 122).

Se quanto ao financiamento eleitoral os legisladores foram recompensados, resta agora saber se todos foram reeleitos. Quase todos. Dos 33 membros da comissão que tentaram a reeleição apenas três não conseguiram: o então primeiro-vice presidente da comissão, Anselmo de Jesus (PT/RO), o ex-coordenador da Frente da Agropecuária, Valdir Colatto (PMDB/SC) e o ambientalista Fernando Marroni (PT/RS). Entretanto, uma vez que ficaram entre os suplentes mais bem colocados, já retornaram à Casa.

Nas eleições de 2010, a Câmara contou com a reeleição de 55\% dos parlamentares. Na Comissão Especial, 91\% dos membros que buscaram se reeleger foram bem sucedidos. Pode-se dizer, então, que eles obtiveram recompensas por suas atuações, ainda mais se comparado com a taxa de reeleição obtida pela Casa. Não há como evidenciar o vínculo ou não com a atuação na reforma florestal, mas há como se afirmar que os parlamentares devem ter acertado em seus cálculos sobre as preferências e potenciais preferências de seus eleitores e, principalmente, sobre como elas se tornariam recompensa ou punição. 


\section{Conclusão}

Este trabalho se propôs a analisar o processo de reforma do Código Florestal. A motivação para o estudo decorre das excepcionalidades de sua tramitação geradas pelo alto grau de polarização e polêmica da matéria. O conflito dentro do Executivo e dentro do PT foi demonstrado pela ausência de uma proposição legislativa governamental, como era comum em outras políticas ambientais, e pela divisão parlamentar na votação no Plenário da Câmara dos Deputados. Nessas condições, o jogo de forças inerente ao Congresso foi determinante no processo deliberativo e na reforma resultante. Assim, sem a dimensão governo e oposição, o debate foi polarizado por outras coalizões.

As questões centrais buscaram responder como se deu a construção da agenda da reforma e quais escolhas e decisões das coalizões foram decisivas para o processo. $\mathrm{O}$ primeiro tema utilizou-se das principais ideias do modelo de multiple streams. Confirmou-se que na formação da agenda do Código Florestal, a existência de cada tipo de fluxo não era suficiente para a reforma passar para a agenda decisória, ou seja, ser objeto de decisões substanciais como a edição de uma lei. A ação de empreendedores da política, no caso a frente ruralista, foi substancial para que os fluxos se unissem quando a janela de oportunidade estivesse aberta. Fora isso, o fluxo político de mudanças internas, período de eleições e início de um novo governo influenciou tanto o momento da reforma ser pautada quanto as circunstâncias de defesa das propostas.

Sobre as coalizões, o foco se deu nas estratégias das lideranças e no cálculo das decisões parlamentares. Utilizando-se substancialmente da teoria de Arnold (1990), considerou-se a premissa de que a meta da reeleição, ou sobrevivência política, é o que determina a atuação desses atores. Dessa forma, as escolhas devem se pautar pela probabilidade dos atos gerarem ou não recompensa eleitoral. Para isso, os legisladores buscam utilizar o processo decisório para moldar a política resultante conforme suas necessidades eleitorais, o que expande o conflito para as regras do processo. Estratégias procedimentais, de persuasão e de modificação são altamente influentes na mobilização sobre a questão e no resultado da política.

Um dos elementos da teoria de Arnold mais influentes na determinação da reforma florestal foi a sua constatação sobre a natureza da política. Se conforme o teor do novo Código Florestal, ele poderia se enquadrar em classes opostas de políticas - 
viáveis ou inviáveis -, o processo da reforma foi substancialmente determinado pela natureza da proposta. Construir uma proposta politicamente rentável para a coalizão tornaria desejável a visibilidade do processo para garantir as recompensas eleitorais. Coube, então, à bancada ambientalista, enquanto coalizão de oposição, buscar formas de demonstrar os custos da política, através da mobilização de outros segmentos sociais.

Quanto aos recursos institucionais, os ruralistas utilizaram-se estrategicamente da previsão regimental sobre a criação das comissões especiais, visando garantir que o processo de debate seria o escolhido por eles. Após moldar o processo, precisariam realizar o trabalho de persuasão. Através das audiências públicas e reuniões externas mobilizaram o relator com a participação expressiva de diversos atores rurais, representando vários segmentos, para mostrar que diferentes realidades necessitavam de mudanças na legislação. E, finalmente, já no Plenário da Casa, a votação em separado da emenda 164 demonstra que não houve tentativa de delegação de questões polêmicas ao Executivo. Pelo contrário, a aprovação da emenda ruralista foi comemorada como uma grande vitória por essa bancada, visto que facilitou o vínculo da aprovação dessa matéria com a atuação de cada parlamentar. Portanto, a definição da natureza da política e a apropriação de recursos institucionais determinaram algumas vitórias da bancada ruralista: (i) pautar a reforma na agenda decisória - algo indesejado pelo governo e pelos ambientalistas; (ii) persuadir o relator sobre a necessidade de mudança conseguiram superar a agenda negativa com a legitimação de outros setores sociais defendendo a proposta; e, (iii) aumentar a visibilidade do processo - mobilização das audiências e reuniões externas e emenda 164, para poderem reivindicar o crédito eleitoral.

O histórico e perfil de cada bancada também apontam fatores influentes no desempenho de cada lado. A descrição da bancada ruralista demonstra que a construção de uma coalizão nesse setor não seria algo penoso. Tanto no Congresso quanto fora dele, os indivíduos ligados ao tema buscam unificação do comando para consolidar a presença nas instituições do Estado. Em contrapartida, a bancada ambientalista não obteve as mesmas capacidades de mobilizar uma ampla coalizão e determinar procedimentos que afetassem a proposta adversária. O governo poderia ter atenuado essa correlação desproporcional de forças. E, provavelmente, era com o que os 
ambientalistas contavam, visto que desde a gestão de Marina Silva no MMA, a participação das ongs do setor marcou-se pelo vínculo direto com o Poder Executivo. Porém, a instabilidade governamental do período, seja pelas mudanças na pasta ambiental, seja pela falta de consenso sobre a matéria, impediu grandes intervenções, facilitando o trabalho da bancada ruralista.

Este estudo entende que uma análise sobre o restante da tramitação da reforma também é necessária. Enquanto o Senado como casa revisora contou com maior interlocução com o Executivo, a segunda análise na Câmara repetiu a soberania dos interesses rurais, de forma que a matéria foi parcialmente sancionada e contou com a edição de uma medida provisória. Entretanto, se o objeto deste trabalho abrange a organização e atuação dos principais interesses envolvidos, a dinâmica da política propiciada pela análise das audiências e do relatório da Comissão foi suficiente. Essa fase inicial de definição da agenda e dos moldes do processo legislativo foi o período em que os interesses se agruparam, formando as coalizões e, especificamente quanto aos legisladores, decidindo as melhores formas de se atingir as recompensas eleitorais. Não se pretende esgotar a análise dessa reforma apenas com este estudo, mas, ao menos, demonstrar a necessidade de se aprofundar e compreender as escolhas e ações dos interesses envolvidos. 


\section{REFERÊNCIAS}

ALMINTA, Eveline C. Depoimento sobre a reforma do Código Florestal. Entrevistadora: Amanda Campanini, Brasília, DF, 2013.

ALVES, Eliseu; CONTINI, Elisio; HAINZELIN, Etienne. Transformações da Agricultura Brasileira e Pesquisa Agropecuária. Cadernos de Ciência \& Tecnologia, Brasília, v. 22, n. 1, p. 37-51, jan./abr. 2005

ARAÚJO, Suley M. V. G. Coalizões de Advocacia na Formulação da Política Nacional de Biodiversidade e Florestas. Dissertação de Mestrado. Instituto de Ciência Política, Universidade de Brasília, 2007.

; JURAS, Ilidia da A. G. Martins. Debate sobre o Código Florestal: Análise do Texto Aprovado pela Câmara dos Deputados. Consultoria Legislativa da Câmara dos Deputados. Agosto de 2011.

; CALMON, Paulo C. Entidades da Sociedade Civil, Coalizões de Defesa e Politica Ambiental no Brasil. Apresentado; International Research Society for Public Management Regional Conference, Dublin, 2011.

Entrevistadora: Amanda Campanini, Brasília, DF, 2013.

- Depoimento sobre a reforma do Código Florestal.

ARNOLD, R. Douglas. The Logic of Congressional Action. New Haven, Yale University Press, 1990

BARCELOS, Eduardo Álvares da Silva; BERRIEL, Maycon Cardoso. Práticas Institucionais e Grupos de Interesse: a Geograficidade da Bancada Ruralista e as Estratégias Hegemônicas no Parlamento Brasileiro. XIX Encontro Nacional de Geografia Agrária, São Paulo, pp. 1-32, 2009.

BAUMGARTNER, F. e JONES, B. (2007) "Ponctuated-equilibrium theory: explaining stability and change in public policymaking". In: Sabatier, P. (org.). Theories of the policy process. Cambridge: Westview.

BRUNO, Regina Angela Landim. Senhores da Terra, Senhores da Guerra: a nova face política das elites agroindustriais. Rio de Janeiro: Forense Universitária: UFRRJ, 1997. 
CÂMARA DOS DEPUTADOS. Agricultura familiar será lançada hoje, veiculada em 15/11/2011 pela Agência Câmara. Disponível em:

http://www2.camara.gov.br/agencia/noticias/AGROPECUARIA/194341-FRENTE-DAAGRICULTURA-FAMILIAR-SERA-LANCADA-HOJE.html - acesso em 29 de agosto de 2012.

CÂMARA DOS DEPUTADOS. Projeto de Lei n. 1876/1999: Comissão Especial do Código Florestal Brasileiro. Disponível em: http://www2.camara.gov.br/atividadelegislativa/comissoes/comissoes-temporarias/especiais/53a-legislaturaencerradas/pl187699. Acesso em 26/06/2012

CÂMARA DOS DEPUTADOS. Projeto de Lei n. 5.367/2009: Comissão Especial do Código Florestal Brasileiro. Disponível em: http://www.camara.gov.br/proposicoesWeb/fichadetramitacao?idProposicao=437370. Acesso em 07/09/2012

CÂMARA DOS DEPUTADOS. Regimento Interno da Câmara dos Deputados. Brasília, 1989. Disponível em: http://www2.camara.gov.br/atividadelegislativa/legislacao/regimento-interno-da-camara-dos-deputados/ricdtextoatualizado. Acesso em 26/06/2012

CARVAlHO, Luiz A. C. Depoimento sobre a reforma do Código Florestal. Entrevistadora: Amanda Campanini, Brasília, DF, 2013.

COHEN M.; MARCH J.; OLSEN, J. A garbage Can model of organizational choice. Administrative Science, Quartely, v. 17, p 1-25, 1972

CONTAG. $1^{\circ}$ Grito da Terra do Brasil. Disponível em http://www.contag.org.br/index.php?modulo=portal\&acao=interna\&codpag=257\&nw= 1 - acesso em 15 de março de 2013.

CORADINI, Odaci Luiz. Frentes parlamentares, representação de interesses $e$ alinhamentos políticos. Rev. Sociol. Polit. [online], v.18, n.36, p. 241-256, 2010.

COX, G. W. e McCUBBInS, M. D. Legislative Leviathan. Party government in the House. Berkeley, University of California Press. 1993

CNA. Sobre o Sistema CNA. Disponível em: http://www.canaldoprodutor.com.br/sobre-sistema-cna/sistema-cna - acesso em 21 de junho de 2013 
DIAP. Bancada ruralista aumenta com o reforço de novos parlamentares. Disponível em

http://www.diap.org.br/index.php?option=com_content\&view=article\&id=15500\&Item $\underline{\mathrm{id}=300}-$ acesso em 21 de junho de 2013

DOLABELLA, Rodrigo H. C. Depoimento sobre a reforma do Código Florestal. Entrevistadora: Amanda Campanini, Brasília, DF, 2013.

EMBRAPA. História da Embrapa. Disponível em: http://hotsites.sct.embrapa.br/pme/historia-da-embrapa - acesso em 21 de junho de 2013

FIGUEIREDO, Angelina Cheibub, LIMONGI, Fernando. Reforma da previdência $e$ instituições políticas. Novos Estudos CEBRAP, n. 51, pp. 63-90, jul. 1998.

FRENTE PARLAMENTAR AMBIENTALISTA, Composição, Entidades Parceiras e Estatuto. Disponível em: http://www.frenteambientalista.com/. Acesso em 23/06/2012

FRENTE PARLAMENTAR DA AGROPECUÁRIA, Composição, Entidades Parceiras e Estatuto. Disponível em: http://www.fpagropecuaria.com.br/. Acesso em $23 / 06 / 2012$

GANEM, Roseli Senna. Prazo para destruição do berço esplêndido: até quando? Consultoria Legislativa da Câmara dos Deputados. 2010. Disponível em: http://www2.camara.gov.br/documentos-e-pesquisa/fiquePorDentro/temas/codigoflorestal_2_edicao/estudo-consultora-roseli . Acesso em 21/06/12

JACOBI, Pedro. Movimento ambientalista no Brasil. Representação social $e$ complexidade da articulação de práticas coletivas. In: Ribeiro, W. (org.) Publicado em Patrimônio Ambiental - EDUSP - 2003.

LEAL, Victor Nunes. (1948). Coronelismo, Enxada e Voto. São Paulo: Editora AlfaÔmega. 1993.

LIMONGI, Fernando P. "O Novo Institucionalismo e os Estudos Legislativos: A Literatura Norte-Americana Recente". Revista Brasileira de Informação Bibliográfica em Ciências Sociais, BIB, nº 37, 1994. 
LINDBLOM, Charles E. (1959). “The Science of Muddling Through", Public Administration Review, 19: 79-88.

KINGDON, John. Agendas, alternatives, and public policies. Nova York, Harper Collins, 2011 (1984).

KREHBIEL, Keith. Information and Legislative Organization, Ann Arbor, Michigan University press, 1991.

MAYHEW, David. Congress, The Electoral Connection. New Haven, Yale University, 2004 (1974).

MMA (MINISTÉRIO DO MEIO AMBIENTE). Mapas de cobertura vegetal dos biomas brasileiros. Brasília: MMA, 2007.

MENDONÇA, Sonia Regina. O Plano Nacional de Reforma Agrária e as entidades patronais rurais do sudeste brasileiro na década de 1980. In: Segundas Jornadas de História Regional Comparada, Porto Alegre. Anais das Segundas Jornadas de História Regional Comparada. Porto Alegre : PUCRS, pp. 1-20, 2005.

MIRANDA, E. E.; CARVALHO, C. A.; SPADOTTO, C. A.; HOTT, M. C.; OSHIRO, O. T.; HOLLER, W. A.; Alcance Territorial da Legislação Ambiental e Indigenista. Campinas: Embrapa Monitoramento por Satélite, 2008. Disponível em: <http://www.alcance.cnpm.embrapa.br/>. Acesso em 21/06/2012.

REBELO, Aldo. Discurso proferido em Plenário da Câmara dos Deputados, 11/05/2011. Disponível em:

http://www.camara.gov.br/proposicoesWeb/prop_mostrarintegra?codteor=874051\&file name $=$ PEP+1+PL187699+\%3D\%3E+PL+1876/1999 - acesso em 21 de junho de 2013

SABATIER, P. and WEIBLE, C. (2007) "The advocacy coalition framework: innovations and clarifications". In: Sabatier, P. (org.). Theories of the policy process. Cambridge: Westview.

SAUER, S. et. all. O Parlamento e a criminalização dos movimentos de luta pela terra: um balanço da CPMI da Terra. Revista da Associação Brasileira de Reforma Agrária ABRA, v. 33, n. 2. São Paulo, 2006. 
SILVA, $\quad$ Marina. $\quad$ Biografia $\quad$ disponível em http://www.minhamarina.org.br/biografia/index.php - acessado em 15 de março de 2013

SIQUEIRA FILHO, Geraldo A. Depoimento sobre a reforma do Código Florestal. Entrevistadora: Amanda Campanini, Brasília, DF, 2013.

TSE. Prestação de Contas. Disponível em http://www.tse.jus.br/ - acessado em 18 de julho de 2013

UDR. Breve Histórico da UDR. Disponível em: http://www.udr.org.br/historico.htm acesso em 21 de junho de 2013

VIEIRA, Liszt; CADER, Renato. A política ambiental do Brasil ontem e hoje. Eco21, 2007. Disponível em: http://www.eco21.com.br/textos/textos.asp?ID=1601. Acesso em: $28 / 02 / 13$

VIGNA, Edélcio. Bancada ruralista: um grupo de interesse. Argumento nº 8. Brasília, INESC, 2001.

Edélcio. Bancada Ruralista: o maior grupo de interesse no Congresso Nacional. Argumento nº 12. Brasília, INESC, 2007.

VIOLA, Eduardo e LEIS, Hector. 1992. “A evolução das políticas ambientais no Brasil, 1971-1991: do bissetorialismo preservacionista para o multisetorialismo orientado para o desenvolvimento sustentável”. In: HOGAN, Daniel e VIEIRA, Paulo. (orgs.) Dilemas Sócioambientais e Desenvolvimento Sustentável.Campinas, Editora da Unicamp. 


\section{ANEXOS}

\section{Anexo 1. Entidades parceiras da Frente Parlamentar da Agropecuária}

ABAG - Associação Brasileira do Agronegócio

ABCS - Associação Brasileira de Criadores de Suínos

ABCZ - Associação Brasileira dos Criadores de Zebu

ABIOVE - Associação Brasileira da Indústria de Óleo Vegetal

ABRAF - Associação Brasileira de Florestas Plantadas

ABRAISCA - Associação Brasileira das Empresas Fabricantes de Iscas Inseticidas ABRAMILHO - Associação Brasileira dos Produtores de Milho

ABRAPA - Associação Brasileira dos Produtores de Algodão

AFUBRA -Associação dos Fumicultores do Brasil

AGROBIO - Associação de Empresas de Biotecnologia na Agricultura e na Agroindústria

AMPA - Associação Matogrossense dos Produtores de Algodão

ANAPA - Associação Nacional dos Produtores de Alho

ANDEF - Associação Nacional de Defesa Vegetal

ANFALPET - Associação Nacional dos Fabricantes de Alimentos para Animais de Estimação

APCACAU - Associação dos Produtores de Cacau

APROSOJA BRASIL - Associação dos Produtores de Soja do Brasil

ASSOCITRUS - Associação Brasileira de Citricultores

CITRUS BR - Associação Nacional de Exportadores de Sucos Cítricos

CNA - Confederação Nacional da Agricultura

IBRAC - Instituto Brasileiro da Cachaça

IBRAF - Instituto Brasileiro de Frutas

OCB - Organização das Cooperativas do Brasil

ORPLANA - Organização dos Plantadores de Cana da Região Centro-Sul do Brasil SINDIRAÇÕES - Sindicato Nacional da Industria de Alimentação Animal

SRB - Sociedade Rural Brasileira

UBABEF - União Brasileira de Avicultura 
UNICA - União da Indústria da Cana-de-acúcar 


\section{Anexo 2. Entidades parceiras da Frente Parlamentar Ambientalista}

ABIPTI - Associação Brasileira das Instituições de Pesquisa Tecnológica

ABIRP - Associação Brasileira das Indústrias Recicladoras de Papel

Amigos do Futuro

Associação Escola Alto do Paraíso

CEMPRE - Compromisso Empresarial para Reciclagem, Ecodata, Ecocâmara

FBONS - Fórum Brasileiro de Ongs e Movimentos Sociais para o Meio Ambiente e o

Desenvolvimento

FIESP - Federação das Indústrias do Estado de São Paulo

FSC/BR - Forest Stewardship Council (Conselho Brasileiro de Manejo Florestal),

FUNATURA - Fundação Pró-Natureza

Greenpeace Brasil

IBRAD - Instituto Brasileiro de Administração para o Desenvolvimento

IDEIA - Instituto de Desenvolvimento e Integração Ambiental

Instituto Ipanema

Imaflora - Instituto de Manejo e Certificação Florestal e Agrícola

Instituto de Pesquisa Etnográfica

ISPN - Instituto, Sociedade, Preservação e Natureza

IPAM - Instituto de Pesquisa Ambiental da Amazônia

ISA - Instituto Socioambiental, Instituto Terra Mater Brasilis

IPE do Cerrado

Jardim Botânico

Preserve a Amazônia

Rede Mata Atlântica

RENCTAS - Rede Nacional de Combate ao Tráfico de Animais Silvestres

SOS Mata Atlântica

WSPA - World Society for the Protection of Animals (Sociedade Mundial para Proteção dos Animais)

WWF Brasil 


\section{Anexo 3. Audiências Públicas}

Audiência Pública de 27 de outubro de 2009 - Brasília (DF)

MARCOS MAIA PORTO - Gerente de Meio Ambiente da Agência Nacional de Transportes Aquaviários - ANTAQ.

$\square \square$ MÁRIO MONDOLFO - Superintendente de Infraestrutura Rodoviária da Agência Nacional de Transportes Terrestres - ANTT.

Audiência Pública de 3 de novembro de 2009 - Brasília (DF)

$\square$ RAIMUNDO DEUSDARÁ FILHO - Diretor da Área de Gestão dos Empreendimentos de

Irrigação e Presidente em Exercício da Companhia de Desenvolvimento dos Vales do São

Francisco e do Parnaíba - CODEVASF.

$\square \square$ LUIZ ANTÔNIO PAGOT - Diretor-Geral do Departamento Nacional de Infraestrutura

de Transportes - DNIT.

Audiência Pública de 10 de novembro de 2009 - Brasília (DF)

GUSTAVO RIBAS CURSIO - Pesquisador da EMBRAPA Florestas, de Colombo/PR.

$\square \square$ CELSO MANZATO - Chefe da EMBRAPA Meio Ambiente, Jaguariúna/SP.

$\square \square$ EDUARDO DELGADO ASSAD - Pesquisador da EMBRAPA Informática, Agropecuária

de Campinas/SP.

Audiência Pública de 12 de novembro de 2009 - Brasília (DF)

$\square$ FÁBIO FELDMANN - Ex-Deputado Federal Constituinte.

$\square$ JOSÉ CARLOS DE ALMEIDA AZEVEDO - Doutor em Física e ex-Reitor da

Universidade de Brasília.

$\square \square$ PAULO AFFONSO LEME MACHADO - Doutor em Direito Ambiental e Professor da

UNIMEP - Universidade Metodista de Piracicaba.

Audiência Pública de 13 de novembro de 2009 - Maceió (AL)

JOSÉ MARINHO JÚNIOR - Secretário-Adjunto de Estado da Agricultura e do Desenvolvimento Agrário.

$\square \square$ LUCIANO BARBOSA - Presidente da Associação dos Municípios Alagoanos AMA.

$\square \square$ ÁLVARO ARTHUR LOPES DE ALMEIDA - Presidente da Federação da Agricultura e 
Pecuária do Estado de Alagoas.

$\square \square$ ANTÔNIO VITORINO DA SILVA - Presidente da Federação dos Trabalhadores na

Agricultura do Estado de Alagoas.

$\square \square$ FERNANDO JOSÉ MENDES PINTO - Presidente do Instituto para Preservação da Mata Atlântica.

$\square \square$ ALEX GAMA DE SANTANA - Secretário Estadual do Meio Ambiente e dos Recursos

Hídricos de Alagoas.

$\square \square$ SÉRGIO TOLEDO - Deputado Estadual de Alagoas.

$\square$ JUDSON CABRAL - Deputado Estadual de Alagoas.

$\checkmark$ RUI PALMEIRA - Deputado Estadual de Alagoas.

$\checkmark$ GILVAN BARROS - Deputado Estadual de Alagoas.

Audiência Pública de 14 de novembro de 2009 - Petrolina (PE)

JÚLIO LOSSIO - Prefeito de Petrolina, Estado de Pernambuco.

$\rightarrow$ JAIRTON FRAGA ARAÚJO - Representante da Prefeitura de Juazeiro, Estado da Bahia.

$\square \square$ LUCIANA SANTOS - Secretária de Ciência, Tecnologia e Meio Ambiente do Estado de

Pernambuco.

$\square \square$ WALTER YUKIO HORITA - Presidente da Associação de Agricultores e Irrigantes da

Bahia.

$\square \square$ IVAN PINTO DA COSTA - Representante da Federação da Agricultura do Estado da

Bahia.

$\square \square$ NELSON ANANIAS FILHO - Representante da Confederação da Agricultura e Pecuária

do Brasil - CNA e da Federação da Agricultura do Estado de Pernambuco.

$\square$ RITA ROSA DA SILVA - Representante da Federação dos Trabalhadores na Agricultura

do Estado de Pernambuco.

JOSÉ WILSON DE ALMEIDA - Ambientalista.

VITÓRIO RODRIGUES - Ambientalista.

Audiência Pública de 19 de novembro de 2009 - Cuiabá (MT)

$\square$ JOSÉ GERALDO RIVA - Deputado Estadual, Presidente da Assembléia Legislativa de

Mato Grosso.

$\square \square$ DILCEU DAL BOSCO - Deputado Estadual de Mato Grosso.

$\checkmark$ BLAIRO MAGGI - Governador do Estado de Mato Grosso. 
$\checkmark$ LUIZ SCALOPPE - Procurador de Justiça de Defesa Ambiental e da Ordem Urbanística

do Estado de Mato Grosso.

$\square$ RUI PRADO - Presidente da FAMATO.

$\square \square$ MAURO MENDES - Presidente do Sistema Federação das Indústrias no Estado de Mato

Grosso.

$\square \square$ MARIA DA GLÓRIA BORGES DA SILVA - Secretária de Assalariados e Assalariadas

Rurais da FETAGRI.

$\square \square$ FERNANDO GöRGEN - Prefeito de Querência/MT e Presidente da Associação de Municípios do Baixo Araguaia.

$\square \square$ PERCIVAL MUNIZ - Deputado Estadual de Mato Grosso.

$\checkmark$ RICARDO ARIOLI - Representante do setor canavieiro/MT.

$\checkmark$ RUBIMAR BARRETO SILVEIRA - Vice-Presidente do Conselho Regional de

Engenharia, Arquitetura e Agronomia de Mato Grosso - CREA/MT.

$\square \square$ JOAQUIM PAIVA DE PAULA - Presidente da AMEF.

$\square \square$ ROBSON AMORIM MACHADO - Vereador do Município de Juína/MT.

$\square \square$ NETO GOUVEIA - Representante dos pantaneiros.

$\square \square$ IVANOR MIOTTO - Agricultor.

$\triangle$ DENIZ ESPEDITO SERAFINI - Presidente da Associação Brasileira de Propriedades

Rurais.

\section{Audiência Pública de 21 de novembro de 2009 - Colíder (MT)}

$\neg$ JOSÉ GERALDO RIVA - Deputado Estadual, Presidente da Assembléia Legislativa de

Mato Grosso.

$\checkmark$ DILCEU DAL BOSCO - Deputado Estadual de Mato Grosso.

$\checkmark$ SILVAL BARBOSA - Governador em Exercício do Estado de Mato Grosso.

$\checkmark$ CELSO PAULO BANAZESKI - Prefeito do Município de Colíder, Mato Grosso.

$\checkmark$ NILTON SANTOS - Deputado Estadual de Mato grosso.

$\square$ VALTER NEVES MOURA - Presidente do Sindicato dos Trabalhadores Rurais de Guarantã do Norte/MT, representante da FETAGRI.

$\square \square$ ANA LÚCIA STEFANELLO - Advogada, OAB/MT.

$\square \square$ ROGÉRIO RODRIGUES - Secretário de Meio Ambiente e Desenvolvimento Sustentável

do Município de Sniop/MT.

$\checkmark$ MARCELO MAOSKI - Secretário de Meio Ambiente do Município de Apicás/MT.

$\checkmark$ VICENTE DA RIVA - Presidente do Sindicato Rural de Alta Floresta/MT.

$\square$ MUNEFUMI MATSUBARA - Produtor rural.

$\square \square$ ANTÔNIO CARLOS PEREIRA GALVAN - Representante do Sindicato Rural de Sinop

e da Federação da Agricultura e Pecuária do Estado de Mato Grosso - FAMATO. 
$\square$ ARNÓBIO VIEIRA DE ANDRADE - Presidente do Grupo de Trabalho do Programa

Marcelândia 100\% Legal.

$\square$ ADALBERTO NAVAIR DIAMANTE - Prefeito de Marcelândia/MT.

$\checkmark$ BETINHO - Presidente do Sindicato Rural de Guarantã do Norte/MT.

$\square$ ANTÔNIO LUIZ CÉSAR DE CASTRO - Prefeito de Nova Canaã do Norte/MT.

$\square \square$ MARCELO DE CASTRO SOUZA - Presidente da Câmara de Guarantã do Norte/MT.

$\neg$ JOÃO SIMONI - Presidente do Sindicato Rural de Colíder/MT.

$\square \square$ DANIEL ROBSON DA SILVA - Presidente da Cooperativa Agropecuária Mista Terra

Nova Ltda - COOPERNOVA.

$\square \square$ MAURO FERONATO - Presidente do Sindicato das Indústria de Móveis do Norte de

Mato Grosso - SIMONORTE.

HÉLIO PEREIRA DE SOUZA - Assessor Jurídico do Município de Terra Nova do Norte/MT.

Audiência Pública de 22 de novembro de 2009 - Novo Progresso (PA)

Sem notas ou registros.

Audiência Pública de 24 de novembro de 2009 - Brasília (DF)

$\square$ CARLOS MINC - Ministro de Estado do Meio Ambiente.

Audiência Pública de 26 de novembro de 2009 - Brasília (DF)

$\checkmark$ SÉRGIO LEITÃO - Diretor de Políticas Públicas do Greenpeace.

$\square \square$ RAUL DO VALLE - Coordenador-Adjunto do Programa de Direito e Política

Socioambiental do ISA - Instituto Socioambiental.

$\square \square$ LUIZ HENRIQUE GOMES DE MOURA - Representante da Articulação Nacional de

Agroecologia - ANA.

$\square \square$ ANDRÉ LIMA - Pesquisador do Instituto de Proteção Ambiental da Amazônia IPAAM.

Audiência Pública de 27 de novembro de 2009 - Campo Grande (MS)

$\square$ MÁRCIO CAMPOS MONTEIRO - Secretário-Adjunto de Estado de Meio Ambiente, do

Planejamento, da Ciência e Tecnologia de Mato Grosso do Sul.

$\square \square$ SÉRGIO SEIKO YONAMINE - Presidente da Agência Estadual de Regulação de Serviços Públicos de Mato Grosso do Sul - AGEPAN.

$\square \square$ EDUARDO CORRÊA RIEDEL - Vice-Presidente da Federação de Agricultura e Pecuária do Estado de Mato Grosso do Sul - FAMASUL. 
ZÉ TEIXEIRA - Deputado Estadual de Mato Grosso do Sul.

$\checkmark$ VANESSA RIBEIRO LOPES - Presidenta da Comissão Ambiental da OAB, Mato Grosso

do Sul.

$\square \square$ SOLANGE FÁTIMA SPOSITO - Representante do Instituto Ambiental IMASUL.

$\square \square$ JÁSIO - Agricultor.

$\square \square$ ROBERTO - Diretor de Desenvolvimento do Instituto de Meio Ambiente de Mato grosso

do Sul.

$\square \square$ LUIZ CALVO RAMIRES JÚNIOR - Presidente da Associação Sul-MatoGrossense de

Produtores e Consumidores de Florestas Plantadas - REFLORE-MS.

$\square \square$ LIONI DE SOUZA FIGUEIRÓ - Engenheiro Agrimensor do Instituto de Meio Ambiente de Mato Grosso do Sul - IMASUL.

$\square \square$ MAURÍCIO BONIFÁCIO DELALIBERA - Representante da Federação da Agricultura

e Pecuária do Mato Grosso do Sul - FAMASUL.

$\checkmark$ WILSON MATEUS BRUSMAENO - Participante.

\section{Audiência Pública de 1 de dezembro de 2009 - Brasília (DF)}

$\square$ FRANCISCO DE ASSIS COSTA - Professor Associado do núcleo de altos Estudos Amazônicos (NAEA) e do Programa de Pós-Graduação da Universidade Federal do Pará.

$\square \square$ LUIZ CARLOS BALDICERO MOLION - Professor do Instituto de Ciências Atmosféricas da Universidade Federal de Alagoas.

$\square \square$ PAULO YOSHIO KAGEYAMA - Professor da ESALQ - Universidade de São Paulo.

\section{Audiência Pública de 3 de dezembro de 2009 - Cafelândia (PR)}

$\square \square$ JOSÉ ROBERTO COELHO - Representante do Sindicato Rural de Goioerê, Estado do

Paraná.

$\square$ JOSÉ LINO - Produtor rural.

$\checkmark$ SILVÉRIO CONSTANTINO - Produtor rural.

GENÉSIO CLEMENTE - Produtor rural.

$\checkmark$ PEDRO AVANCINI - Produtor rural.

\section{Audiência Pública de 4 de dezembro de 2009 - Assis Châteaubriant (PR)}

$\square$ DALILA JOSÉ DE MELLO - Prefeita do Município de Assis Chateaubriand, Estado do

Paraná. 
$\square$ DIRCEU VIEIRA DE PAULA - Presidente da Câmara de Vereadores de Assis Chateaubriand, Estado do Paraná.

$\square \square$ NELSON COSTA - Superintendente-Adjunto das Organizações das Cooperativas do

Estado do Paraná - OCEPAR.

$\square$ ALFREDO LANG - Presidente da Cooperativa C. Vale, no Estado do Paraná.

$\square \square$ VALDEMAR EDUARDO KAISER - Presidente do Núcleo Regional dos Sindicatos

Rurais do Oeste do Paraná.

$\square \square$ PAULO MACEDO - Representante da Federação dos Trabalhadores da Agricultura do

Estado do Paraná.

$\square \square$ APARECIDO JOSÉ WEILLER JÚNIOR - $1^{\circ}$ Vice-Presidente da Associação dos Municípios do Oeste do Paraná.

$\square \square$ ROGÉRIO MASSING - Representante da Associação de Câmaras e Vereadores do Oeste

do Paraná - ACAMOP.

$\square \square$ ROGÉRIO PASQUETTI - Presidente da Associação dos Produtores Lindeiros ao Parque

Nacional do Iguaçu e Lago do Itaipu, Estado do Paraná.

$\square$ ÉLIO RUSH - Deputado Estadual do Paraná.

$\square$ DUÍLIO GENARI - Deputado Estadual do Paraná.

ELTON WETER - Deputado Estadual do Paraná.

$\checkmark$ ODIR CIVIDINI - Produtor Rural.

$\checkmark$ LUIZ CARLOS MIOTTO - Produtor Rural e Presidente da Associação dos

Suinocultores

de Palotina, Paraná.

$\neg$ LOTÁRIO HEIN - Produtor Rural.

CLÁUDIO HOFFMANN - Produtor Rural.

$\square \square$ MARIA ELCI VENÂNCIO DA SILVA - Prefeita do Município de Guaíra, Estado do

Paraná.

$\square$ GÉRARD MOSS - Vice-Presidente do Sindicato Rural Patronal da Cidade Gaúcha.

BRAZ REBERTI PEDRINI - Presidente do Sindicato Rural Patronal de Altônia, Paraná.

$\square \square$ JOÃO APARECIDO PEGARORO - Presidente do Sindicato dos Trabalhadores Rurais

de Assis Chateaubriand, Paraná.

$\square \square$ WALTER ANDREI DAL'BOIT - Produtor Rural de Assis Chateaubriand, Paraná.

$\checkmark$ LUCILENE DIAS DA SILVA - Produtora Rural de Umuarama, Paraná.

$\square$ NELSON CARNIEL - Agricultor de São Jorge do Patrocínio, Paraná.

ORACI MIAKI - Agricultor de Nova Aurora, Paraná.

$\checkmark$ ÉDIO HOSDA - Agricultor de Terra Roxa, Paraná.

$\checkmark$ RICARDO SÍLVIO CHAPLA - Presidente da COPAGRIL de Marechal Cândido

Rondon, Paraná.

$\square$ VALTER PITOL - Presidente da COPACOL. 
$\checkmark$ CASTILLO LUIZ HENDGES - Agricultor.

$\checkmark$ GUILHERME MOERS - Produtor Rural.

$\neg$ ERNI ARNDT - Agricultor e Produtor Rural de frango de Nova Santa Rosa, Paraná.

$\square$ ADEMIR GENERO - Gerente do SICREDI, em Palotina, Estado do Paraná.

$\square \square$ JOSÉ HENRIQUE OLIVEIRA NETO - Agricultor e Engenheiro Agrônomo em Assis

Chateaubriand, Estado do Paraná.

$\checkmark$ WILLIAM HOFFMANN - Agricultor.

GERSON ARALDI - Produtor Rural.

$\square$ ALFREDO MOTTA MARTINS - Agricultor de Assis Chateaubriand, Estado do Paraná.

$\square \square$ ALTAIR DE PÁDUA - Agricultor e representante do Sindicato Rural Patronal de Terra

Roxa, Paraná.

$\square \square$ FERANDO ENGLER - Engenheiro Agrônomo e Produtor Rural.

Audiência Pública de 8 de dezembro de 2009 - Brasília (DF)

$\square \square$ Reinhold Stephanes - Ministro de Estado da Agricultura, Pecuária e Abastecimento - MAPA.

Audiência Pública de 10 de dezembro de 2009 - Brasília (DF)

$\square \square$ LUIZ CARLOS SILVA MORAIS - Professor do Centro Universitário do Norte Paulista -

UNORP.

$\square \square$ IVO MELLO - Engenheiro Agrônomo e Primeiro-Secretário da Federação Brasileira de

Plantio Direto.

CARLOS EDUARDO FRISCKMANN YOUNG - Professor de Economia da Universidade Federal do Rio de Janeiro.

$\square \square$ VITOR HUGO RIBEIRO BURKO - Presidente do Instituto Ambiental do Estado do

Paraná.

Audiência Pública de 11 de dezembro de 2009 - Chapecó (SC)

WOLMIR DE SOUZA - Presidente da Associação Catarinense de Criadores de Suínos.

ALCEU LORENZON - Diretor-Presidente da Alcaplas.

$\neg$ HILÁRIO COTTSELIG - Presidente da Federação dos Trabalhadores na Agricultura de

Santa Catarina, FETAESC.

$\square$ ENORI BARBIERI - Vice-Presidente da FAESC. 
$\square \square$ ELIAS VALMIR BALDISSERA - Presidente do Sindicato da Indústria da Construção e

de Artefatos de Concreto Armado do Oeste de Santa Catarina - SINDUSCON.

$\square \square$ MARCOS ANTÔNIO ZORDAN - Presidente do Sindicato e Organização das

Cooperativas do Estado de Santa Catarina no Município de Joaçaba.

$\square \square$ MARCOS WEISS - Gerente de Desenvolvimento Ambiental da Fundação do Meio

Ambiente do Estado de Santa Catarina - OCESC.

$\square$ SILVIO VOLTARIM - Representante das cerâmicas de Santa Catarina.

$\square \square$ RICARDO - Vereador

$\square \square$ GLAUCO OLINGER - Engenheiro Agrônomo.

$\square \square$ SAMANTA PINEDA - Consultora Jurídica da Frente Parlamentar da Agropecuária.

Audiência Pública de 3 de fevereiro de 2010 - Assis (SP)

$\square$ ÉZIO SPERA - Prefeito do Município de Assis, Estado de São Paulo.

$\neg$ FÁBIO DE SALLES MEIRELLES - Presidente da Federação da Agricultura do Estado

de São Paulo - FAESP.

BRAZ AGOSTINHO ALBERTINI - Presidente da Federação dos Trabalhadores na Agricultura do Estado de São Paulo - FETAESP.

$\square \square$ EDIVALDO DEL GRANDE - Presidente da Organização das Cooperativas do Estado de

São Paulo - OCESP.

$\square \square$ IVAN CARNEIRO CASTANHEIRO - Promotor de Justiça do Centro de Apoio Operacional Cível e de Tutela Coletiva de São Paulo.

$\square \square$ RICARDO KANTHACK - Diretor do Polo Médio de Paranapanema, da Agência Paulista

de Tecnologia dos Agronegócios - APTA.

$\square \square$ MARCOS SAWAYA JANK - Presidente da União da Indústria de Cana-de-Açúcar

UNICA.

$\square$ MAURO BRAGATO - Deputado Estadual de São Paulo.

$\square \square$ MARCELO DE SOUZA PECCHIO - Prefeito Municipal de Quatá, Estado de São Paulo,

e Presidente do Consórcio Intermunicipal do Vale do Paranapanema - CIVAP.

$\square \square$ NELSON ROBERTO BUGALHO - Promotor do Meio Ambiente do Município de

Presidente Prudente, Estado de São Paulo.

$\square \square$ REINALDO CUSTÓDIO DA SILVA - Prefeito do Município de Palmital, Estado de São

Paulo.

$\square$ CARLOS ALBERTO MANTOVANI - Presidente da Organização NãoGovernamental

Entidade Ecológica e Educacional do Vale do Paranapanema - ENVAPA.

$\square \square$ FÁBIO MEIRELLES FILHO - Vice-Presidente da Confederação Nacional da Agricultura

e Pecuária do Brasil — CNA. 
$\neg$ PAULO ARLINDO DE OLIVEIRA - Representante do Secretário de Agricultura e Abastecimento do Estado de São Paulo e Diretor Regional da Coordenadoria de

Assistência Técnica Integral - CATI, da Secretaria de Agricultura e Abastecimento do Estado.

$\neg$ JOSÉ REINALDO BASTOS - Presidente da Câmara Setorial da Mandioca do Estado de

São Paulo e Vereador no Município de Cândido Mota.

Audiência Pública de 3 de fevereiro de 2010 - Ribeirão Preto (SP)

$D$ DÁRCY VERA - Prefeita do Município de Ribeirão Preto.

$\neg$ JÕ̃O SAMPAIO - Secretário de Agricultura e Abastecimento do Estado de São Paulo.

LUÍS CARLOS SILVA DE MORAES - Professor universitário.

CRISTINA GODOY DE ARAÚJO FREITAS - Coordenadora da Área do Meio Ambiente

do Centro de Apoio Operacional Cível e de Tutela Coletiva do Ministério Público do Estado de São Paulo.

$\square \square$ MÔNIKA BERGAMASCHI - Diretora Executiva da Associação Brasileira do Agronegócio da Região de Ribeirão Preto - ABAG/RP.

$\checkmark$ JOAQUIM AUGUSTO DE AZEVEDO SOUZA - Presidente do Sindicato Rural de Ribeirão Preto.

$\square \square$ BRAZ AGOSTINHO ALBERTINI - Presidente da Federação dos Trabalhadores na Agricultura do Estado de São Paulo.

$\square \square$ MÁRCIO LOPES DE FREITAS - Presidente da Organização das Cooperativas Brasileiras.

HÉLIO NEVES - Presidente da Federação dos Empregados Rurais Assalariados do

Estado de São Paulo - FERAESP.

$\neg$ JOSÉ MARIA DA COSTA - Advogado.

$\square \square$ SIMONE KANDRATAVICIUS - Representante da Associação Cultural Ecológica Pau-

Brasil.

$\square$ ISMAEL PERINA JUNIOR - Representante da ORPLANA.

$\checkmark$ GUE OLIVEIRA - Representante do Assentamento Mário Lago.

$\square$ PAULO KAGEYAMA - Professor da USP.

CARLOS GANBARINI - Estudante de Direito.

CAMILA - Estudante de Agronomia da ESALQ.

$\square \square$ NEUSA BERALDI

Audiência Pública de 4 de fevereiro de 2010 - Belo Horizonte (MG)

ARLEN SANTIAGO - Representante da Assembléia Legislativa de Minas Gerais.

$\square$ ROBERTO SIMÕES - Presidente da Federação da Agricultura e da Pecuária do Estado

de Minas Gerais. 
$\square$ EDUARDO ANTÔNIO ARANTES DO NASCIMENTO - Representante da Federação

dos Trabalhadores na Agricultura do Estado de Minas Gerais.

$\square \square$ VÍTOR FEITOSA - Presidente do Conselho de Meio Ambiente da Federação das Indústrias do Estado de Minas Gerais.

$\square \square$ JOSÉ CARLOS DE CARVALHO - Secretário de Estado de Meio Ambiente e

Desenvolvimento Sustentável de Minas Gerais.

$\square \square$ LUCIANO BALDINI - Promotor de Justiça.

$\square \square$ PAULO AFONSO ROMANO - Secretário-Adjunto de Agricultura, Pecuária e Abastecimento do Governo do Estado de Minas Gerais.

$\square \square$ MARIA DARCI RICAS - Superintendente Executiva da associação Mineira de Defesa do

Meio Ambiente.

$\square$ FÁBIO AVELAR - Presidente da Comissão de Meio Ambiente e Recursos Naturais da

Assembleia Legislativa de Minas Gerais.

$\square \square$ SEBASTIÃO VALVERDE - Professor da Universidade de Viçosa, Minas gerais.

$\square \square$ HUMBERTO CANDEIRAS - Representante da associação dos Municípios Mineiros.

$\square \square$ BERNARDO DE VASCONCELLOS - Presidente da Associação Mineira de Silvicultura.

$\checkmark$ JÚLIO GONÇALVES PEREIRA - Vice-Presidente da Federação da Agricultura e Pecuária do Estado de Minas Gerais.

$\square \square$ EUGÊNIO MENDES DINIZ - Presidente do Sindicato Rural de Pará de Minas.

$\checkmark$ VANDERLEI JANGROSSI - Suplente de Deputado Estadual de Minas Gerais.

\section{Audiência Pública de 4 de fevereiro de 2010 - Uberaba (MG)}

Não há notas ou registro.

Audiência Pública de 5 de fevereiro de 2010 - Manaus (AM)

$\neg$ JOSÉ LOBO - Deputado Estadual do Amazonas.

$\checkmark$ LUIZ CASTRO - Deputado Estadual do Amazonas.

$\square$ ADEMAR BANDEIRA - Presidente da Câmara Municipal de Manaus.

$\square \square$ ERON BEZERRA - Deputado Estadual e Secretário de Produção Rural do Estado do

Amazonas.

$\square$ MARIO CESAR MANTOVANI - Representante da SOS Mata Atlântica.

$\square \square$ MUNIR JÚNIOR - Representante da Federação da Agricultura do Estado do Amazonas.

$\square \square$ NILO D’ÁVILA - Coordenador de Políticas Públicas e representante do Greenpeace.

IZIDRO MATHEUS DE SENA BARROS - Participante.

CÁSSIA FERREIRA DA SILVA - Representante do Movimento dos Trabalhadores 
Rurais Sem Terra.

$\square \square$ SÉRGIO GONÇALVES - Participante.

Audiência Pública de 6 de fevereiro de 2010 - Boa Vista (RR)

ALMIR SÁ - Presidente da Federação da Agricultura de Roraima.

SÉRGIO PILLON GUERRA - Representante do Governo do Estado de Roraima.

$\square \square$ ERCI DE MORAES - Representante da Assembleia Legislativa do Estado de Roraima.

$\square \square$ LUCIANA SURITA DA MOTTA MACEDO - Presidente da Fundação Estadual de Meio

Ambiente, Ciência e Tecnologia - FEMACT.

PAULA ARAUTO - Representante da Secretaria Estadual do Meio Ambiente.

$\square \square$ SÍLVIO DA SILVA - Presidente da Sociedade em Defesa dos Índios do Norte de

Roraima

- SODIUR.

$\square \square$ NELSON MASSAMI ITIKAWA - Representante da Associação dos Arrozeiros de Roraima.

$\square \square$ LAERTE THOMÉ - Presidente da Associação dos Produtores da Serra da Lua, Estado de

Roraima.

$\square \square$ SÍLVIO DE CARVALHO - Presidente do Sindicato e Organização das Cooperativas

Brasileiras no Estado de Roraima.

CIRO CAMPOS - Representante do Coletivo Ambiental do Lavrado.

$\checkmark$ FÁBIO ALMEIDA - Presidente do Diretório Regional do Partido Comunista do Brasil -

PcdoB de Roraima.

$\square \square$ GILBERTO MARCELINO - Representante do Município de Caracaraí.

Audiência Pública de 25 de fevereiro de 2010 - Rio Branco (AC)

EDVALDO MAGALHÃES - Presidente da Assembleia Legislativa do Estado do Acre.

EUFRAN AMARAL - Secretário de Meio Ambiente do Estado do Acre.

$\square \square$ ASSUERO DOCA VERONEZ - Presidente da Federação da Agricultura e Pecuária do

Estado do Acre.

$\square \square$ MARIA SEBASTIANA OLIVEIRA DE MIRANDA - Presidente da Federação dos Trabalhadores na Agricultura do Estado do Acre.

$\square \square$ PATRÍCIA AMORIM REGO - Procuradora do Ministério Público no Estado do Acre.

JÚLIO BARBOSA - Representante do Conselho Nacional dos Seringueiros.

$\checkmark$ IRANI BRAGA - Representante da Serra do Divisor.

$\neg$ IDALINA ONOFRE - Deputada Estadual pelo Estado do Acre. 
$\square \square$ LEONARDO CUNHA DE BRITO - Professor do Centro de Ciências Jurídicas e Sociais

Aplicadas e Professor de Direito Ambiental da Universidade Federal do Acre.

$\square \square$ LUIZ CALIXTO - Deputado Estadual pelo Estado do Acre.

AURICÉLIO AZEVEDO - Representante da Reserva Chico Mendes.

INÁCIO KAXINAWÁ - Cacique da terra indígena Caucho.

ADELAIDE DE FÁTIMA - Representante da Associação dos Moradores.

$\square$ ADAMOR DAS MERCÊS - Vereador de Sena Madureira.

ELDER ANDRADE DE PAULA - Professor da Universidade Federal do Acre.

$\checkmark$ RAIMUNDO LACERDA DA SILVA - Vereador de Brasileia.

$\square$ NÉSIA MORENO - Engenheira Florestal.

$\checkmark$ RONALD POLANCO RIBEIRO - Representante do Tribunal de Contas.

JUDSON FERREIRA VALENTIM - Representante da EMBRAPA.

$\checkmark$ SÉRGIO BARROS - Produtor Rural.

$\square$ RAIMUNDO SOUZA DA SILVA - Presidente da SINPASA.

$\checkmark$ ROSILDO RODRIGUES - Representante do Sindicato dos Trabalhadores Rurais de Brasiléia.

ADOLAR ROSELLA - Representante do Sindicato Rural de Sena Madureira.

\section{Audiência Pública de $1^{\circ}$ de março de 2010 - Teresina (PI)}

DALTON MACAMBIRA - Secretário de Meio Ambiente do Governo do Estado do Piauí.

$\square$ CARLOS AUGUSTO MELO CARNEIRO - Presidente da Federação de Agricultura do

Estado do Piauí.

$\square \square$ LUIZ FERNANDO DE MELO - Engenheiro Agrônomo e membro da Comissão de Meio

Ambiente do Estado do Piauí - CMA.

$\square \square$ JOÃO LUZARDO FILHO - Representante da Procuradoria Regional do Trabalho.

$\checkmark$ FRANCISCO RODRIGUES SOARES - Presidente da Federação Rio Parnaíba,

Conselheiro do Conselho Nacional do Meio Ambiente, representando as ONGs da Região

Nordeste.

$\square \square$ AVELAR AMORIM - Presidente da Associação dos Engenheiros Agrônomos do Piauí.

$\square \square$ CELSO JOSÉ MONTEIRO FILHO - Biólogo do IBGE.

$\square \square$ SÉRGIO BORTOLOZZO - Vice-Presidente da Federação da Agricultura do Estado do

Piauí.

$\square \square$ FLÁVIO MOURA FÉ - Presidente da Comissão de Meio Ambiente da Ordem dos Advogados do Brasil, Piauí.

$\square \square$ THEMOSTOCLES FILHO - Deputado Estadual e Presidente da Assembleia Legislativa

do Estado do Piauí.

$\square$ EDSON FERREIRA - Deputado Estadual. 
$\square$ ANTONIO FELIX - Deputado Estadual.

$\square \square$ NEMA SOUZA BEZZERA - Funcionária Pública do Tribunal de Justiça de São Luís,

Estado do Maranhão.

DIONÍSIO NETO - Representante da Rede Ambiental do Piauí - REAPI.

$\square \square$ ANTÔNIO RIBEIRO NETO - Representante da Fundação de Defesa Ecológica do Cerrado.

$\square \square$ JOSÉ ANCHIETA ROSAL - Representante dos produtores rurais do sul do Estado do

Piauí.

\section{Audiência Pública de 2 de março de 2010 - Imperatriz (MA)}

$\square \square$ SEBASTIÃO MADEIRA - Prefeito do Município de Imperatriz, Estado do Maranhão.

$\square \square$ MARCELO TAVARES SILVA - Presidente da Assembleia Legislativa do Estado do

Maranhão.

$\square \square$ HAMILTON MIRANDA - Presidente da Câmara de Vereadores de Imperatriz, Estado do

Maranhão.

$\square \square$ WASHINGTON LUIZ CAMPOS RIO BRANCO - Secretário de Meio Ambiente do

Estado do Maranhão.

$\square \square$ GASTÃO VIEIRA - Deputado Federal e Secretário de Planejamento do Estado do Maranhão.

$\square \square$ AFONSO SÉRGIO FERNANDES RIBEIRO - Secretário de Agricultura, Pecuária e Pesca do Estado do Maranhão.

$\square \square$ JADSON MEDEIROS DE LAGO - Secretário-Adjunto do Desenvolvimento Agrário e

Presidente do Sindicato dos Produtores Rurais do Estado do Maranhão.

$\square \square$ RAIMUNDO COELHO - Vice-Presidente da Federação da Agricultura e Pecuária do

Estado do Maranhão.

$\square \square$ FRANCISCO SALES DE OLIVEIRA - Presidente da Federação dos Trabalhadores da

Agricultura do Estado do Maranhão.

$\square \square$ CLÁUDIO AZEVEDO - Representante da Federação das Indústrias do Estado do Maranhão.

$\square \square$ CARLOS MARQUES - Presidente do Sindicato Rural de Imperatriz, Estado do Maranhão.

$\square \square$ MARCO TÚLIO DOMINICI - Presidente da Associação dos Criadores do Maranhão.

$\square \square$ SABINO SIQUEIRA DA COSTA - Secretário de Desenvolvimento do Município de

Imperatriz, Estado do Maranhão. 
$\square$ VALDINAR BARROS - Deputado Estadual do Maranhão.

DEOCLIDES MACEDO - Prefeito de Porto Franco, Estado do Maranhão.

$\checkmark$ PENALDON JORGE MOREIRA - Deputado Estadual.

$\square$ WILSON ARAÚJO DA SILVA - Professor da Universidade Estadual do Maranhão

UEMA.

$\neg$ SRA. CONCEIÇÃO - Representante de 40 entidades civis de Imperatriz/MA

CARLOS LEE - Representante do Coletivo Arte Alternativa de Imperatriz/MA.

RUBENS FAVAL - Representante do Comitê Amazônia Somos Nós.

$\checkmark$ DERLISON SAMPAIO - Presidente da associação dos Criadores de Alto Alegre do

Pindaré e Amarante do Maranhão.

$\square \square$ LUCIANO VILELA - Representante da Federação da Agricultura do Estado do

Tocantins.

$\square \square$ RAIMUNDO NONATO - Produtor rural.

$\square \square$ MAURONI ALVES CANGUSSU - Produtor rural.

$\square \square$ FRANCISCO MARTINS DE SOUZA - Assentado da Reforma Agrária, agricultor familiar.

RODES JEREMIAS - Produtor rural.

GUILHERME MAIA ROCHA - Engenheiro Agrônomo.

$\checkmark$ VICENTE GOMES DE OLIVEIRA - Produtor rural.

ALBERTO CANTANHEDO - Movimento Social Ambientalista da Amazônia.

ERNO SORVOS - Conselheiro Estadual da OAB.

ALOÍSIO MELO - COOPERVAL

$\neg$ JOÃO OLÍMPIO - Assessor da Prefeitura de Carolina.

$\checkmark$ FRANKCINATO DA SILVA BATISTA - Professor aposentado da UFMA.

$\square \square$ EDMILSON CARVALHO - Representante da ONG Comando Florestal, Ambiental,

Guardiões do Verde.

Audiência Pública de 9 de março de 2010 - Corumbá (MS)

$\neg$ RUITER CUNHA DE OLIVEIRA - Prefeito Municipal de Corumbá, Mato Grosso do Sul.

$\checkmark$ WALFRIDO MORAES TOMÁS - Pesquisador da EMBRAPA.

ROBERTO RICARDO GONÇALVES - Diretor de Desenvolvimento do Instituto de Meio

Ambiente de Mato Grosso do Sul.

$\checkmark$ RICARDO EBOLI - Vice-Prefeito do Município de Corumbá, Mato Grosso do Sul.

$\square \square$ EDUARDO CORREA RIEDEL - Presidente em exercício da Federação da Agricultura e

Pecuária de Mato Grosso do Sul - FAMASUL.

$\square \square$ RAPHAEL KASSAR - Presidente do Sindicato Rural de Corumbá, Mato Grosso do Sul.

MARIA CRISTINA LANZA - Vereadora.

$\square$ OTÁVIO LACERDA - Pantaneiro. 


\section{Audiência Pública de 24 de março de 2010 - Brasília (DF)}

$\square \square$ JOSÉ WELLINGTON BARROSO DE ARAÚJO DIAS - Governador do Estado do Piauí.

$\square \square$ RICARDO EBOLI - Vice-Prefeito do Município de Corumbá, Estado do Mato Grosso do

Sul.

$\checkmark$ WALFRIDO MORAES TOMÁS - Pesquisador da EMBRAPA Pantanal.

$\checkmark$ JÚLIO BARBOSA DE AQUINO - Presidente do Conselho Nacional dos Seringueiros do

Acre.

\section{Audiência Pública de 29 de março de 2010 - Colombo (PR)}

$\square$ HELTON DAMIN DA SILVA - Chefe-Geral da EMBRAPA Florestas.

$\square \square$ JOSÉ ANTÔNIO CAMARGO - Prefeito do Município de Colombo, Estado do Paraná.

JOÃO BOSCO DE VASCONCELLOS GOMES - Pesquisador da EMBRAPA.

GUSTAVO RIBAS CURCIO - Pesquisador da EMBRAPA Florestas.

ALEXANDRE UHLMANN - Pesquisador da EMBRAPA Florestas.

EDILSON BATISTA DE OLIVEIRA - Engenheiro Agrônomo e Pesquisador da EMBRAPA Floresta.

ESTEFANO PALUDZYSZYN FILHO - Pesquisador da EMBRAPA Floresta.

$\square$ YEDA MARIA MALHEIROS DE OLIVEIRA -

$\square \square$ JOSÉ ROBERTO SCOLFORO - Professor e Pró-Reitor de pesquisa da Universidade

Federal de Lavras, Minas Gerais.

$\square$ SEBASTIÃO RENATO VALVERDE - Engenheiro Florestal e Professor da Universidade

Federal de Viçosa, Minas Gerais.

$\square \square$ CLÁUDIO MÁRIO MUNDSTOCK - Engenheiro Agrônomo.

$\square \square$ SAMANTA PINEDA - Consultora Jurídica para assuntos ambientais da Frente Parlamentar da Agropecuária.

$\square \square$ LEONARDO PAPP - Engenheiro de Desenvolvimento Humano da Organização das

Cooperativas Brasileiras - OCB.

ROBERTO GAVA - Presidente da Câmara de Desenvolvimento Florestal da Federação

das Indústrias do Paraná - FIEP.

\section{Audiência Pública de 30 de março de 2010 - Brasília (DF)}

RENATO CAIAFFO DA ROCHA - Presidente da Federação das Associações dos Arrozeiros do Rio Grande do Sul - FEDERARROZ.

$\square \square$ DÁRSIO CALAIS - Engenheiro Florestal, representante da Associação Mineira de Silvicultura. 
Audiência Pública de 6 de abril de 2010 - Brasília (DF)

$\square$ FERNANDO GORGEN - Prefeito do Município de Querência, Estado de Mato Grosso.

$\square \square$ FERNANDO DE ANDRADE MARTINS - Promotor de Justiça da Comarca de Franca,

Estado de São Paulo.

$\square \square$ ROBERTO ANDRADE GRECELLÉ - Consultor Técnico em Pecuária e

Desenvolvimento Sustentável.

Audiência Pública de 7 de abril de 2010 - Brasília (DF)

CARLOS ADOLFO BANTEL - Engenheiro Florestal, representando o Conselho Federal

de Engenharia, Arquitetura e Agronomia - CONFEA.

$\square \square$ ALBERTO ERCÍLIO BROCH - Presidente da Confederação dos Trabalhadores na Agricultura - CONTAG.

Audiência Pública de 13 de abril de 2010 - Brasília (DF)

ROBERTO LUIZ LEME KLABIN - Presidente da ONG SOS Mata Atlântica.

$\checkmark$ FERNANDO HENRIQUE DA FONSECA - Presidente da Associação Brasileira de Produtores de Florestas Plantadas - ABRAF. 